\title{
Desobramento constelações clínicas e políticas do comum
}

Tese apresentada à Faculdade de Educação da Universidade de São Paulo, para obtenção do título de doutora em Educação.

Área de concentração:

Filosofia e Educação

Orientação:

Prof. Dr. Celso Fernando Favaretto.

SÃo PAULO

2010 
Autorizo a reprodução e divulgação total ou parcial deste trabalho, por qualquer meio convencional ou eletrônico, para fins de estudo e pesquisa, desde que citada a fonte.

Catalogação na Publicação

Serviço de Biblioteca e Documentação

Faculdade de Educação da Universidade de São Paulo

37.01 Inforsato, Erika Alvarez

I43d Desobramento : constelações clínicas e políticas do comum / Erika Alvarez Inforsato ; orientação Celso Fernando

Favaretto. São Paulo : s.n., 2010.

$217 \mathrm{p}$.

Tese (Doutorado - Programa de Pós-Graduação em Educação. Área de Concentração : Filosofia e Educação ) - Faculdade de Educação da Universidade de São Paulo.

1. Educação - Filosofia 2. Psicologia clínica 3. Terapia ocupacional 4. Ética - Política I. Favaretto, Celso Fernando, orient. 
INFORSATO, Erika Alvarez. DESOBRAMENTO - constelações clínicas e políticas do comum. Tese. (Doutorado) Programa de Pós-Graduação em Educação, Linha de Pesquisa Filosofia e Educação, da Faculdade de Educação da Universidade de São Paulo. - FEUSP. São Paulo, 2010.

Aprovada em:

Banca Examinadora 

ao meu orientador, Celso Favaretto, pela generosa e aguda companhia;

aos meus pais, Hélio e Ivete, que insistiram em me apresentar um comum;

ao Alexandre, pela presença e pela solidão;

e aos outros, quaisquer importantes, que persistem em estar junto. 

"Estar vivo é uma grossa indiferença irradiante. Estar vivo é inatingível pela mais fina sensibilidade.

Estar vivo é inumano. [...] o não humano é o centro irradiante de um amor neutro em ondas hertzianas"

Clarice Lispector

Adélia Faustino, Adriana Barin, Alejandra Riera, Alexandre Bernardes, Alexandre Henz, Amélia Montero, Ana Carmen del Collado, Ana Cláudia Baldani, Ana Goldenstein, Ana Lúcia Marques, Andréa Amparo, Aparecida Rodrigues da Silva, Bel Ghirardi, Benjamim Canguçu de Paula, Bruna Taño, Cássio Santiago, Celso Favaretto, Christiana Morais, Cristiane Pitteli, Cristina Weffort, Daniela Canguçu, Diogo dos Santos, Eduardo Lettiere, Eduardo Silva, Eliane Dias de Castro, Elisa Band, Elizabeth Araújo Lima, Evaldo Wollandi, Fábio Turra, Fabrício Pedroni, Fernando Barros, Gisele Asanuma, Gláucia Crystal, Guilherme Ribeiro, Helena Alvarez, Helio Inforsato, Heloísa Canguçu de Paula, Isabela Valent, Ivete Alvarez, Iza Cremonine, John Laudenberger, José Salvador Sanches, Juliana Jardim, Juliano Pessanha, Kleber da Silva, Lara Christina Malimpensa, Léo Lui Cavalcanti, Léon Kossovitch, Lis Henz, Lúcia Tordin, Luciana Carvalho, Marcos Antonio dos Santos, Mari Dotti, Mariana Pan, Mariel Zasso, Onés Cervelin, Paula Francisquetti, Peter Pélbart, Priscyla Mammy, Raquel Meirelles, Renan Duarte, Renata Buelau, Ronaldo Inforsato, Sidnei Cazeto, Simone Mina, Sonia Favaretto, Tereza Fuji, Valéria Manzalli, Wagner Menezes, Yoshiko Nagahashi. 

INFORSATO, Erika Alvarez. DESOBRAMENTO - constelações clínicas e políticas do comum. Tese. (Doutorado) Programa de Pós-Graduação em Educação, Linha de Pesquisa Filosofia e Educação, da Faculdade de Educação da Universidade de São Paulo. - FEUSP. São Paulo, 2010.

\section{RESUMO}

Operar na própria escrita um outro modo de pensar e fazer a clínica, liberada de suas utopias humanistas e de suas exigências produtivista, utilitária e socialitarista, é a proposição deste texto. Entrelaçadas em narrativas inventadas, a clínica é aqui fabulada em seus pontos de contágio com alguma arte, aludida em experiências ocorridas junto aos projetos da cia. teatral Ueinzz e do Ateliê Experimental (PACTO - USP) - coletivos constituídos por aqueles cujas trajetórias são marcadas pela loucura, pela deficiência e/ou pela vulnerabilidade social. $O$ texto enfrenta a dificuldade de dizer do que não pode ser dito, contar o invivível de uma experiência que, entretanto, não pode deixar de ser testemunhado. Acrescenta-se a esta complicação, a urgência de um cotidiano profissional, cujo ponto de partida é a terapia ocupacional, que ao lidar com situações-limite demanda respostas das quais não se pode omitir, e que por isto exige posições arrojadas para sustentar alguma indeterminação e não decair em saídas voluntariosas, e em seus correlatos exercícios de poder coercitivos. A importância dos processos de dessubjetivação visam favorecer na clínica outras sensibilidades, outra saúde, que não empreite a vida alheia, mas que a convide a outras experiências. Em narrativas, alguns experimentos são expostos e, na tentativa de evitar encadeamentos previsíveis e ilustrativos, adotam-se estratégias de fabulação, manejando elementos da memória de situações coletivas, de modo a fitar numa ficção verossímil suas verdades circunstanciais. A migração de conceitos do campo da filosofia e das artes para o âmbito da clínica e da política ocorrem por agenciamento e justaposição: o dispositivo de Foucault e Deleuze; o qualquer de Agamben; a multiplicidade e o acontecimento de Deleuze e Guattari; o intelecto geral, de Virno; o comum e o desobramento de Bataille, Nancy e Blanchot. O comum apresenta-se em constelações clínicas e políticas alçadas para acionar o vivo dos acontecimentos; e o desobramento é o pressentimento de uma outra ética, que não faz obra e que se entrevê na clínica, em sua atuação profissional e em suas modulações na escritura.

PALAVRAS-CHAVES: clínica; terapia ocupacional; educação; comum, desobramento. 

INFORSATO, Erika Alvarez. UNWORKING (Desoeuvrement) - clinical and political constellations of the common. (Thesis) Post-Graduation Program in Education, Philosophy and Education Research Line of the School of Education of the University of São Paulo. - FEUSP. São Paulo, 2010.

\begin{abstract}
Operating in the very writing another way of thinking and working the clinic, free from its humanitarian utopias and from its productive, utilitarian and socialistic requirements is the proposition of this text. Interwoven in invented narratives, the clinic comes up here as fables in their points of contagion with some art mentioned in experiences occurred in the projects of the Ueinzz theatre group and of the Experimental Studio (PACTO - USP) - collectives constituted by those whose trajectories have been marked by madness, by deficiency and/or social vulnerability. The text faces the difficulty of saying what should not be said, telling the unlivable of an experience which, however, cannot help being witnessed. To this complication the urgency of a professional daily life is added, whose starting point is occupational therapy which when dealing with limit situations demands answers which one cannot omit, and which, due to that, require daring stances to support some indetermination and not to go for any easy way-out based on one's will, and in their correlated exercises of coercive power. The importance of the de-subjectivation processes target on favoring in the clinic other sensibilities, other health, which do not pry into other people's life, but which invites it to other experiences. In narratives, some experiments are exposed and, in an attempt to avoid predictable and illustrative enchaining, strategies of telling fables are adopted, handling elements of the memory of collective situations in order to see in a verisimilar fiction their circumstantial truths. The migration of concepts of the field of philosophy and of the arts to the ambit of the clinic and politics takes place by assemblage and juxtaposition: Deleuze and Foucault device; Agamben anyone; Deleuze and Guattari multiplicity and occurrence; Virno general intellect; Bataille, Nancy and Blanchot common and desoeuvrement. The common comes up in clinical and political constellations raised to activate the alive in the occurrences; and desoeuvrement is the presentiment of new ethics which does not do any work and from which we can have a glimpse in the clinic, in its professional performance and its modulations in the scripture.
\end{abstract}

KEY WORDS: clinic, occupational therapy; education; common, desoeuvrement. 

[SUMÁRIO]

INTRODUÇÃO

p. 17

Apresentação de uma superfície por vir

PLANO DE CONSISTÊNCIA

p. 33

Plissagens e fissuras do qualquer

DISPOSIÇÃO

p. 63

Fazer comunidade: escrever?

EXPERIMENTOS

p. 79

Narrativas: experiências em abismo

experimento I

p. 95

Cozinhando gentes - heterogeneidade e antropofagia

experimento II

p. 115

Circunstância e Improviso

experimento III

p. 125

La Fonderie - Casamento de campanha

experimento IV

p. 135

Enquete sobre o/nosso entorno (Interruptions)

experimento $\mathrm{V}$

p. 145

Longe, quando a estranheza ameaça tornar-se familiar experimento VI

p. 165

General Inttelect - por onde anda a deficiência?

CONCLUSÃO, SUSPENSÃO

p. 177

Desobramento - estratégias de interferência e ocupação

PÓS-TEXTO

p. 205

Escritos de outrem 

O conflito entre a escritura e a vida, reduzido a tal simplicidade, não pode oferecer nenhum princípio seguro de explicação, inclusive se explicar for aqui apenas o desdobramento de afirmações que se requerem umas às outras para por-se à prova, sem limitar-se. Escrever, viver: como poderia alguém aterse a este enfrentamento de termos precisamente tão mal determinados? Escrever destrói a vida, preserva a vida, exige a vida, ignora a vida, e reciprocamente. Escrever não tem, finalmente, nenhuma relação com a vida, a não ser pela insegurança necessária que a escritura recebe da vida, como a vida a recebe da escritura: uma ausência de relação que tal escritura, enquanto se reúne nela, ao dispensar-se nela, não concorda nunca consigo mesma, somente com a outra que não é ela, que a arruína, ou pior, a perturba."

L'amitié, Maurice Blanchot

* Tradução nossa 
Mote. "Quanto ao motivo que me impulsionou foi muito simples. Para alguns, espero, esse motivo poderá ser suficiente por ele mesmo. É a curiosidade - em todo o caso, a única espécie de curiosidade que vale a pena ser praticada com um pouco de obstinação: não aquela que procura assimilar o que convém conhecer, mas a que permite separar-se de si mesmo. De que valeria a obstinação do saber se ele assegurasse apenas a aquisição dos conhecimentos e não, de certa maneira, e tanto quanto possível, o descaminho daquele que conhece? Existem momentos na vida onde a questão de saber se se pode pensar diferentemente do que se pensa, e perceber diferentemente do que se vê, é indispensável para continuar a olhar ou a refletir. Talvez me digam que esses jogos consigo mesmo têm de permanecer nos bastidores; e que no máximo eles fazem parte desses trabalhos de preparação que desaparecem por si sós a partir do momento em que produzem seus efeitos. Mas o que é filosofar hoje em dia - quero dizer, a atividade filosófica - senão o trabalho crítico do pensamento sobre o próprio pensamento? Se não consistir em tentar saber de que maneira e até onde seria possível pensar diferentemente em vez de legitimar o que já se sabe? Existe sempre algo de irrisório no discurso filosófico quando ele quer, do exterior, fazer a lei para os outros, dizer-lhes onde está a sua verdade e de que maneira encontrá-la, ou quando pretende demonstrar-se por positividade ingênua; mas é seu direito explorar o que pode ser mudado, no seu próprio pensamento através do exercício de um saber que lhe é estranho. O "ensaio" - que é necessário entender como experiência modificadora de si no jogo da verdade, e não como apropriação simplificadora de outrem para fins de comunicação - é o corpo vivo da filosofia, se, pelo menos, ela for ainda hoje o que era outrora, ou seja, uma "ascese", um exercício de si, no pensamento." (FOULCAULT, 1984, p. 13)

\section{Uma superfície por vir}

[...] a estranheza do que não poderia ser comum é o que funda esta comunidade, eternamente provisória e sempre já desertada.

Maurice Blanchot

Escrever, transcorrer num texto sem assegurar-se sobre a propriedade das palavras, apenas sobre o fato de poder dizer. Exercer o fluxo da língua, ter eloquência. Não fazer obra literária, nem acadêmica, sequer fazer obra. Uma proposta que poderia parecer insustentável em se tratando do lugar em que está inscrita: a tese.

Sob o título Paisagens estéticas: experimentação $e$ aprendizagem na clínica, em seu projeto inicial, propus um 
estudo da incidência de questões relacionadas à aprendizagem e à experimentação em certas situações de uma clínica em proximidade com as artes, e fora dos parâmetros habitualmente convencionados para elas, quer os expressos pelas ciências da saúde (exame, prevenção, tratamento, reabilitação), quer aqueles da área da educação (formação, transmissão cultural, desenvolvimento), quer ainda os relativos ao campo social (inserção, inclusão, cidadania, integração). A própria evocação da noção de clínica, ainda que deslocada de sua acepção tradicional, apresenta-se como um problema de pesquisa, que somente na operação do próprio termo poderá delinear seus contornos e aproximar-se de uma definição, na qual deve estar presente a atenção às experiências de sofrimento. $\mathrm{O}$ tema inicial deste estudo foi então motivado por uma suposição experimental, que permanece ainda, de que haja um cognoscível na vida coletiva que prescinda dos atributos pragmáticos de apreensão - pressupostos pela tradição científica e distribuídos pelo senso comum. Isto quer dizer que, numa certa configuração coletiva, parecia haver um modo de entender os acontecimentos que era marginal aos caracteres objetivos tradicionalmente estabelecidos como condição para a aquisição de conhecimento e para a solução de problemas. É um modo de apreensão afetiva e inventiva que não se constitui inédito do ponto de vista científico $^{1}$, mas que ao efetivar-se, mediado pela possibilidade de se estar junto circunstancialmente, torna-se uma conjectura ética: o reconhecimento de uma faculdade simultaneamente política e clínica na experiência comum, que aciona forças singulares para uma exploração.

Uma vez feita a escolha pela profissão de terapeuta ocupacional, exerci algumas aproximações com populações em situação de sofrimento e vulnerabilidade graves (caráter definido

1 Exemplo disto, é a importante pesquisa desenvolvida por Virgínia Kastrup sobre a questão da cognição relacionada à invenção. (KASTRUP, 1999.) 
em função de precariedades econômicas, de deficiências, e/ou de fragilidades mentais) reunidas prioritariamente em situações grupais. Com o tempo, estas aproximações passaram a interrogar os percursos por onde a efetuação de certas experiências e de seus entendimentos se davam. A percepção daquilo que era vivido com elas não coincidia com as prescrições já feitas (fossem as explicações médicas - prederteminadoras de condições de possibilidade -, fossem as sociais - apeladoras de direitos de cidadania pautados em requisições técnico-jurídicas para os denominados processos de inclusão) e isto que escapa a estas configurações convencionais é o que interessou indagar. Não estamos nos referindo a nenhuma ocorrência espetacular, ao contrário, tratam-se de pistas sutis, cujo traço extraordinário está em sua cotidianidade temporária, em que importam os elementos fugidios, relacionados a um exercício profissional na clínica e às situações de vida que dele advém: para quem cuida e para quem é cuidado - não sendo evidentemente possível fixar estas funções de modo rígido, mas apenas tendencial, preservadas as assimetrias correspondentes a cada um.

Estes encontros e aproximações são relevantes na medida em que se inscrevem e assentam-se provisoriamente em superficies. Superfícies que interessam em seu aspecto bidimensional que corrobora na recusa aos procedimentos que supõem profundidade, ou interioridade psicológica, ou ainda identidades fundadas, e com este indeferimento assume que em cada acontecimento o que acontece se dá fora, entre os elementos que o constituem, o atravessam e nele operam. Trabalhar com as superfícies nos permite privilegiar os deslizamentos e fluxos nos quais podemos escoar e transcorrer as narrativas destes acontecimentos, pela justaposição de suas figuras e pelo não-lugar (isto que estamos chamando fora) que, com alegria, ocupam. Diferente de falta de lugar, ocupar o nãolugar acentua o entendimento de que todos os lugares instituídos 
da política estão falidos, que o "social" onde se pretende incluir a todos fracassou, e que a estratégia de ocupação episódica do mundo é um possível interessante, que não fabrica novos lugares, mas discorre pelas superfícies, ocupando sem alojar-se definitivamente a profusão de territórios existentes e em mutação: estado, cidade, domínio, instituição, seita, grupo, ilha, equipe, sindicato, projeto social, escola, política cultural, equipamento de saúde etc. Com efeito, é de passagens e travessias que se fazem estas ocupações e nelas dificilmente ocorrem harmonias ou coexistências concordantes, este alojamento provisório dispara muito mais as inquietudes, perturbações, angústias, forças e vitalidades. E o desejo de pertencer a esta ocupação instável, a esta plataforma ocasional, é uma atração ambígua e tênue: uns vem, outros vão. Espera-se nada, espera-se tudo, sem saber ao certo o que isto significa. E há muitos vazios e pausas, reuniões descontínuas, nenhuma promessa de preenchimento, nenhuma garantia de continuidade.

- E quando acabar?

- A gente sempre vai se encontrar aqui? Onde?

- A semana que vem tem? No mesmo lugar? Na mesma hora?

- Todo mundo vai continuar vindo?

- Como eu vou confiar em você se você um dia não vai estar mais comigo?

- Quando voltamos a nos encontrar?

- Mas quem não vai vir?

Ao eleger a afirmação desta efemeridade como modo de operar e de pensar interessado nas passagens e nos elementos provisórios que constituem estes encontros, certamente não se descomplica o caráter deles, entretanto evita-se sua simplificação, dando a ver o que neles pode favorecer àquilo que 
se pode chamar comum e que engendra uma historicidade, que só pode contar com o que está sendo, com o presente, atento ao compromisso daquele instante, que não o torna antecessor nem sucessor de nenhum outro, mas que se inscreve numa superfície: exterioridade sem pressupostos, sem base, sem fundamentos.

Com isto, é possível enumerar um outro complicador, que decorre deste modo de fazer e dispor a geografia das aproximações nesta clínica não convencional a saber, a precariedade de serviços e recursos oferecidos no âmbito da saúde e da educação pública. Precariedade, no que tange a sua acessibilidade material (vagas para atendimento) e/ou substancial (relevância e sustentabilidade das propostas), e que torna compulsória a pasteurização de programas que à menor diferença que queiram implantar são achatados pela ideia totalizadora de faltar o básico. Tomado por fundamento universal, sobre este básico tudo deve erigir-se e, portanto, dele tudo mais deve proceder. Enquanto este básico não estiver idealmente organizado e funcionante (resquício retardado da sociedade do "bem-estar social" e dos regimes disciplinares), as propostas que assumam outras direções, fora das instituições formais, vêem-se numa atadura em que acabam por inviabilizarse ou permanecer em posições secundárias, quase supérfluas: perfumaria. Na prática, no cotidiano das relações profissionais, seja no campo da saúde ou da educação, isto acentua políticas dicotomizadas, desprezos e anulações de exercícios de derivação taxados como descomprometidos com a gravidade da situação social, tomada em sua pressuposta universalidade. Frequentemente, ocorre a adesão destes projetos “acessórios” (que são muitos) a preceitos de inserção social tais como o trabalho ou a cultura, o que os recoloca numa trajetória alinhada que, na mesma medida em que os protege, desmonta grande parte de sua potência de digressão. 
Para evitar esta adesão inepta, há ainda aqueles que lançam mão de uma espécie de camuflagem, disfarces para efetivar sua força dissonante, cujo propósito não é nada senão desviar-se de erigir princípios e buscar apenas modos de convivialidade e fruição do viver, no sentido de poder fazer melhor uso da vida, vivê-la. Por isto, estes projetos desviantes não estariam, a priori, atrelados a nenhuma instância de produção social, e só o fazem em nome de uma mínima sobrevivência prática; travestidos, eles acabam por contribuir indiretamente (uma vez que isto não está no rol de nenhuma intencionalidade), com o tensionamento dos campos, pelo desencaixe que, mesmo contrafeitos, provocam.

Contudo, há que se ressaltar que não é foco deste estudo fazer objeções a quaisquer estados hegemônicos de coisas, menos ainda estabelecer as ordens de força dos desvios e das adesões. Entretanto, em meio à tentativa de apresentação e afirmação de outros agenciamentos - impermanentes, denominados provisoriamente para efeito de inscrição de seus eventos -, é possível que ocorram alguns confrontos no pensamento. Longe de se avultarem como indícios de qualquer conformação ideal, as constelações que aqui se mostrarão na forma de narrativas buscam enunciar posições, índices de localização que devem tornar evidente sua diferença e podem por isto ser potencializadores de uma vitalidade aos universos da clínica e da política.

Muitos são os movimentos com propostas que tentam firmar-se na qualidade de novas insígnias - de reforma ou renovação -, formas de poder em busca de reconhecimento institucional. Para pensar estes movimentos, vale à pena evocar, conforme a acepção empregada por Agamben, o constante estado de exceção em que nos encontramos atualmente, diante do qual resta-nos experimentar uma grande impotência e buscar por outros modos da política que nos retirem desta imobilidade. 
Viver no estado de exceção transformado em regra significou também que nosso corpo biológico privado se tornou indistinguível de nosso corpo político; que experiências que antes se diziam políticas fossem, de chofre, confinadas a nosso corpo biológico e experiências privadas se apresentassem, repentinamente, fora de nós, como corpo político. Tivemos que nos habituar a pensar e a escrever nessa confusão entre corpos e lugares, entre externo e interno, entre aquilo que é mudo e aquilo que tem voz, entre o que é escravo e o que é livre, entre o que é necessidade e o que é desejo. (AGAMBEN, 1999)

Cientes ou não da precariedade de suas intenções, e do risco de recair sob novas formas do mesmo (de soberania, estado de direitos, princípios de cidadania - sobretudo no âmbito das políticas públicas), estas insígnias facilmente tornam-se emblemáticas e deparam-se com seu efeito avesso: "ditadura do para todos". À semelhança da operação totalitária, com maior ou menor pregnância, estas propostas se apresentam como formas substitutivas das atuais, atribuindo-se um status de superioridade e progresso em relação ao passado, aguardando enaltecimento e legitimação condescendente. Mesmo enquanto novidade, cada uma destas propostas quer dispor-se como modelo, e prossegue impedindo, do mesmo modo que aqueles que as precederam, a proliferação e efetuação de outras formas, sufocando vitais movimentos transgressivos. "Nada é mais esclerosante que o espírito de deferência." (DUBUFFET, 1986, p. 12). Estas propostas não são de início desprezíveis, ao contrário, a maioria delas guarda consigo pontos de partida revolucionários, experiências de êxito e relevância para a vida de muitas pessoas, e uma militância cuja intenção proclamada está preocupada com a questão de garantir a todos uma existência política e opor-se aos funcionamentos preponderantes. Entretanto, na medida em que pretendem responder universalmente a esta questão, inscrita na esfera do direito, tornam-se autoritárias: operam por ideologias e palavras de ordem; impõem o funcionamento democrático; endurecem com os desvios como se para garantir a radicalidade de sua proposição só restasse englobar ou destituir qualquer 
outra proposição. Esta relação entre democracia e totalitarismo surpreende em sua aparente contradição, mas tem sido explorada de modo a verificar sua contiguidade.

É como se, a partir de um certo ponto, todo evento político decisivo tivesse sempre uma dupla face: os espaços, as liberdades e os direitos que os indivíduos adquirem no seu conflito com os poderes centrais simultaneamente preparam, a cada vez, uma tácita porém crescente inscrição de suas vidas na ordem estatal, oferecendo assim uma nova e mais temível instância ao poder soberano do qual desejariam liberar-se. (AGAMBEN, 2002a, p.127)

O risco desta adjacência da reivindicação democrática e da instauração de estados totalitários é uma questão éticoestética, no sentido em que é em sua forma que as lutas políticas confundem-se e se endurecem ao migrar de uma caracterização aberta de reivindicação da vida como objeto político, para uma figuração restrita de afirmação de direitos como objeto jurídico. Isto não as invalida, mas as despotencializa para a defesa da vida em seu potencial bio-político, e pode, num sobressalto, inverter seus propósitos e tornar-se mais um elemento de controle e poder sobre a vida, prescrevendo leis e regramentos, insistindo em restauros e reformas de sua suposta proposição original. Em Notas sobre a política, Giorgio Agamben formula uma questãochave para nosso tempo: "Como uma política ,que seja unicamente voltada à completa fruição da vida, é possível nesse mundo?" (AGAMBEN, 2002b, p. 126). Talvez esta indagação seja um crivo importante para analisar os fluxos de nossas atuais proposições políticas.

Do ponto de vista das artes, a paisagem é coincidente, na medida em que, findo o momento das vanguardas e suas exigências de novidade e ruptura, o que vigora é a indeterminação que necessita inventar suas regras e categorias singulares de modo a definir-se a cada caso (FAVARETTO, 2008, p. 15), o que é consonante ao procedimento clínico. $O$ que predomina em sua existência são as surpresas e incertezas não 
sendo possível, portanto, a seus propósitos, direcionarem-se a uma transformação da vida.

Assim, a arte, de um lado, vaga entre desejos de restauração de projetos e operações que outrora tiveram sentido, "resgatando", como se diz, a possibilidade de articulação entre criação e crítica. Ou então, por outro lado, dedica-se a recodificar, reiterar e eventuar. Aqui e ali surpresas acontecem: um tensionamento de signos da experiência, uma reinterpretação que vira um modo inédito de enunciar, uma reinscrição do simbólico onde só havia repetição, um nexo surpreendente de sensibilidade e pensamento que interfere no circuito da razão comunicativa, repropondo a arte com sentido de intervenção cultural. São esses lampejos, esses acontecimentos que afirmam a potência do puro viver; pois é disto que se trata hoje na arte: reinventar a arte de viver. (FAVARETTO, 2008, p.15)

Diante destas circunstâncias históricas e geográficas, para pensar em acontecimentos coletivos, evitando decair sobre socialitarismos e pequenos fascismos inovacionistas, desfazendo-se do alinhamento dicotômico indivíduo-sociedade e de outros que o acompanham que pretendem naturalizar objetificações históricas. Os elementos do pensamento precisam, então, guiar-se por registros que ultrapassassem estas divisões estanques - obras feitas em nome da razão e do conjecturado bem alheio que é sua promessa. Seria como uma mudança no curso deste leito, desta superfície onde se assentam os lastros do pensamento e de suas operações, para evitar as edificações, escapar a fazer obra, deixar o canteiro aberto ou apenas provisoriamente ocupado, e disparar o funcionamento dos elementos por travessias, por penetrações recíprocas e intermitentes, não mais por oposições. A ausência de obra é uma afirmação. Não se trata de negar a obra ou de propor sua destruição, a ausência de obra é uma deterioração precedente à obra, inevitável e dissidente dela, a relação com sua alteridade, com o outro da obra. Duplos, triplos, múltiplos sujeitos/animais/ coisas que não se oponham, que não disputem um mesmo espaço e funcionem por aproximações e distâncias. Para tanto, 
tomar o coletivo enquanto encontro pontual para onde convergem as singularidades, deixa aberto o trânsito para o pensamento, desviando-se de absolutizações e efetuando relações. Sob noções de rizoma, socius, rede, etc, em estudo, Escóssia e Kastrup apresentam o conceito de coletivo distinguindo-o do social, rejeitando a noção de sociedade como conjunto de indivíduos e incluindo nela a infinidade de outros elementos não-humanos que a compõem em agenciamento.

A noção de rede contribui de modo especial para a ultrapassagem da tensão que sempre existe entre o nível individual e social de fenômenos como a cognição, a emoção ou a ação. Sua novidade diz respeito a dois pontos principais. O primeiro é abrir mão do problema da origem, em proveito da questão da distribuição ou disseminação que caracteriza o processo de engendramento dos seres. $\mathrm{O}$ segundo é renunciar à grande separação estabelecida entre humanos e não-humanos, freqüentemente utilizada para explicar a constituição do psiquismo ou do social. Com base na sociologia das ciências e das técnicas, especialmente nos trabalhos desenvolvidos por Bruno Latour (1994), mas também por outros autores como Michel Callon e John Law (1997), o coletivo pode ser entendido como rede social, desde que se garanta o princípio da heterogeneidade do social, assim como de toda e qualquer entidade, seja ela um indivíduo, uma comunidade, um texto ou um objeto técnico.

[...] É a mesma idéia apresentada por Guattari (1992) quando afirma que o coletivo deve ser entendido "no sentido de uma multiplicidade que se desenvolve para além do indivíduo, junto ao socius, assim como aquém da pessoa, junto a intensidades pré-verbais, derivando de uma lógica dos afetos mais do que de uma lógica de conjuntos bem circunscritos". Desaparece a equivalência entre coletivo e conjunto ou somatório de pessoas. O coletivo é impessoal, é plano de coengendramento dos indivíduos e da sociedade. (ESCOSSIA; KASTRUP, 2005)

Para acrescentar-se a esta trajetória conceitual e operatória, a noção de comum evoca-se aqui, consonante a esta conceituação do coletivo, como um elemento intercessor para um outro modo de proceder enunciações. Ela assume um lugar central neste estudo e será examinada à luz de textos cujos autores adentraram a questão do comum por diferentes perspectivas que, convergindo em certos pontos, têm 
substancializado esta ideia, favorecendo seu uso para indagar e afirmar algumas experiências coletivas.

Inevitável no processo deste escrito, ao realizar aproximações de noções como as de experimentação e de apreensão na multiplicidade, no coletivo, justapor as experiências de convivialidade, a constituição de um comum e a impossibilidade da obra, ou ainda, uma desejada ausência de obra como uma outra saída para a clínica. É este, então, o conjunto que constitui a superfície de deslizamento prioritária da escrita deste trabalho. Com o processo de acabamento, ou melhor, de evolução e suspensão da escrita, outras formulações se fizeram, a fim de apresentar esta superfície de inscrição, até chegar àquela que pareceu melhor convergir ao que se tratava, e que é então aquilo que a intitula: Desobramento: constelações clínicas e políticas para o comum.

Sob esta enunciação concentra-se então este escrito, que pretende deixar vir, de alguns dos inusitados encontros desta clínica, políticas que pautem distâncias favoráveis para se estar junto, em comum. Um pathos convergente àquele do Maio de 68, em que uma convocação súbita, impelia os corpos a estarem juntos, sem preparação ou télos, movidos pelo desejo de uma interrupção indeterminada, vontade de acontecimento.

Presença inocente, "comum presença" (René Char), que ignora seus limites, política pela recusa de excluir o que quer que seja e pela consciência de ser, tal qual, o imediatouniversal, com o impossível como único desafio, mas sem vontades políticas determinadas e, assim, à merce de qualquer sobressalto das instituições formais, contra as quais nos interditávamos reagir. É esta ausência de reação (Nietzsche poderia passar por seu inspirador) que permitiu que se desenvolvesse a manifestação adversa, que teria sido fácil impedir ou combater. Tudo era aceito. A impossibilidade de reconhecer um inimigo, de levar em conta uma forma particular de adversidade, isto vivificava, mas precipitava ao desenlace que, de resto, não tinha necessidade de nada desenlaçar, desde o momento em que o acontecimento ocorrera. ${ }^{2}$ (BLANCHOT, 1983, p. 53-4.)

2 Trad livre do trecho em francês: “[...] Présence innocent, $<<$ commune présence $>>$ (René Char), ignorant ses limites, politique par le refus de 
Texto principal nesta exploração, A comunidade inconfessável (1983) [La communauté inavouable] de Maurice Blanchot, versa de um modo poético sobre questões comuns às que se quer aqui, e por isto ele acompanhará todo o desenrolar do escrito como uma companhia de intensificação, um item de ajuda para elevar em graus o pensamento, fazendo as vezes do que poderíamos denominar um dispositivo clínico: que estabelece relações, faz funcionar, dispõe, acrescenta e subtrai, operacionaliza, enfim, elementos, potencializando suas análises e suas intervenções - que são seu caráter benfeitor e, do mesmo modo, autoritário - risco que pretendo correr, com as prudências necessárias e possíveis.

$\mathrm{Na}$ apresentação constitutiva desta superfície de complicações, o movimento do texto encaminha-se no sentido de um revolvimento de camadas de lembrança e invenção, numa arqueologia em que os estratos não dispõem seus elementos de modo cronológico, sequencial, mas por achados que consumam seus alinhamentos conforme seu aparecimento. Isto resulta em combinações dessemelhantes, que nem sempre podem explicarse, nem comprovar-se, mas que buscamos tornar compreensíveis, construindo com seus usos seus próprios modos de explicitação. Porque o que aqui se escreve não pode e não pretende explicar o vivido, não trata de uma transposição do tipo da vida ao texto, ou 'coleta e análise de dados', ou 'estudo de caso' - estratégias de enunciação referidas à produção de verdade acadêmico-científica. Aqui o dispositivo é simplesmente o

ne rien exclure et la conscience d'être, telle quelle, l'immédiatuniversel, avec l'impossible comme seul défi, mais sans volontés politiques déterminées et, ainsi, à la merci de n'importe quel sursaut des institutions formelles contre lesquelles on s'interdisait de réagir. C'est cette absence de réaction (Nietzsche pouvait passer pour en être 1 'inspirateur) qui laissa se développer la manifestation adverse qu'il eût été facile d'êmpecher ou de combattre. Tout était accepté. L'impossibilité de recconnaître un ennemi, $d$ 'inscrire en compte une forme particulière $d$ 'adversité, cela vivifiait, mais précipitait vers le dénouement, qui, au reste, n'avait besoin de rien dénouer, dès lors que l'événement avait eu lieu." 
escrever, escrever pelo que o vivido impele de desejo e necessidade de dizer; buscar outras experiências de intensidade através da narrativa, para compartilhar eventualmente algo que encontra-se no domínio das sensações, dos regimes de sensibilidade não enunciáveis: sua alteridade.

Pensar a partir da escrita de experiências com as quais se esteve envolvido, "a clínica do clínico", não permite um lugar de neutralidade, de observação asséptica. A função profissional não isola ninguém de seu entorno, e nenhum patamar de exterioridade fica garantido pela posição oficial que se ocupa. Este distanciamento só pode ser fabricado - para o bem e para o mal: seja isentar-se das afecções, seja pensá-las, diferenciá-las. Uma vez produto de uma invenção, esta distância evoca uma outra experiência, que será formulada em enunciados, e que reconhece a impossibilidade de enunciar como testemunha, sobrevivente de um acontecimento que se quer narrar. A este respeito, reporta Jeannne Marie Gagnebin, em prefácio à publicação brasileira do livro de Giorgio Agamben, O que resta de Auschwitz:

o testemunho do sobrevivente somente repousa nesta impossibilidade de autenticidade e sobre o reconhecimento dessa impossibilidade, sobre a consciência aguda de que aquilo que pode - e deve - ser narrado não é o essencial, pois o essencial não pode ser dito. $(2008$, p. 16$)$

O gesto que pode ocorrer na escrita, nada senão o que se passa no próprio ato de escrever: este é o maior propósito deste texto. Por mais estranho que isto figure. Não pelo gosto de não dizer ou não servir a nada, ou por uma recusa cínica de compartilhamento, nem por qualquer atribuição sublime à experiência, mas pela impossibilidade, diante do ilimitado da vida, de dizer o que precisa ser dito, só restando escrever, no limite da palavra, o que é possível. Isto não é inaugural. Está no 
rastro do pensamento de escritores que de distintos modos tocam a questão.

Em Agamben encontramos a formulação:

A experiência que está aqui em questão não tem nenhum conteúdo objetivo, e não é formulável em proposições sobre um estado de coisas ou uma situação histórica. Ela nada tem a ver com um 'estado', mas com um evento de linguagem, ela não concerne a tal ou tal gramática, mas, por assim dizer, ao factum loquendi como tal. Ela deve ser concebida como uma experiência concernente à matéria mesma ou à potência do pensamento (em termos spinozanos, uma experiência de potentia intellectus, sive de libertate). (2002b, p. 128)

De outro modo, em Blanchot se enuncia:

Escrever é produzir a ausência de obra (a desconstrução da obra). Pode também dizer-se que escrever é a ausência da obra tal como ela se produz através da obra e atravessando-a. Escrever como desconstrução da obra (no sentido ativo desta palavra) é o jogo insensato, o acaso entre razão e desrazão. ${ }^{3}$ (1973, p. 27)

E, ainda, numa carta, em Artaud se revela:

Estreei na literatura escrevendo livros para dizer que não podia escrever nada. Meu pensamento, quando eu tinha algo a escrever, era o que mais me faltava. [...] Nunca escrevi senão para dizer que jamais fiz nada, que nada poderia fazer e que, ao fazer alguma coisa, na realidade eu não fazia nada. Toda a minha obra foi construída, e só poderia sê-lo, sobre o nada [...] (apud BLANCHOT, 2001, p. 51)

Em geral, nas pesquisas relacionadas às experiências na clínica, habitualmente verifica-se que o autor/pesquisador é chamado a uma responsabilidade dita "ética" para com seus parceiros de profissão. Com efeito, esta responsabilização desvela-se muito mais como uma questão corporativa, já que mesmo nas versões mais generosas - de transmissão e partilha de um hipotético saber -, em geral, estas pesquisas, ingenuamente ou não, estão a serviço de consolidações acadêmicas e do

3 Trad. livre do trecho: "Escribir es producir la ausencia de obra (la desconstrucción de la obra). Puede también decirse que escribir es la ausencia de obra tal como ella se produce a través de la obra y atravesándola. Escribir como desconstrucción de la obra (en el sentido activo de esta palabra) es el juego insensato, el azar entre razón y sinrazón." 
mercado de trabalho especializado e diversificado. Ao modo deste estudo, reconhecer e sustentar uma condição de impossibilidade na escrita está, portanto, pautado num procedimento ético, de alteridade. Ético, no sentido esclarecedor de Agamben quando alude que "a ética é a esfera que não conhece culpa nem responsabilidade: ela é, como sabia Spinoza, a doutrina da vida feliz" (AGAMBEN, 2002a). Não poder dizer sobre uma experiência, atrair-se pela ausência de obra que possa haver ao reportá-la, está desvinculado de culpas e responsabilidades e, embora por vezes seja necessário admiti-las, fazê-lo significa adentrar o âmbito do Direito, por-se fora do campo da ética.

Isto não é efetivamente uma des-culpa para a dimensão impotente deste escrito, entretanto, desde a ocasião dos acontecimentos decisivos que me impeliram a fazer este estudo, reconheço forças que nos dotam da capacidade de fruir a vida e, se não para nada, sem eximir-me do compromisso que me cabe em relação às experiências idas e as que estão por vir, é para o acionamento destas forças que desejo que o pensamento e a escrita aqui convirjam: forças de superfície: forças do fora. 
[PLANO DE CONSISTÊNCIA]

\begin{abstract}
Dobras. "O plano de consistência ou de composição (planômeno) se opõe ao plano de organização e de desenvolvimento. A organização e o desenvolvimento dizem respeito à forma e à substância: ao mesmo tempo desenvolvimento da forma e formação de substância ou de sujeito. Mas o plano de consistência ignora a substância e a forma: as hecceidades, que se inscrevem nesse plano, são precisamente modos de individuação que não procedem pela forma nem pelo sujeito. O plano consiste, abstratamente mas de modo real, nas relações de velocidade e lentidão entre elementos não formados, e nas de composições de afectos intensivos correspondentes ("longitude" e "latitude" no plano). Num segundo sentido, a consistência reúne concretamente os heterogêneos, os disparates enquanto tais: garante a consolidação dos conjuntos vagos, isto é, das multiplicidades do tipo rizoma. Com efeito, procedendo por consolidação, a consistência necessariamente age no meio, pelo meio, e se opõe a todo plano de princípio ou de finalidade." (DELEUZE; GUATTARI, 1997b, p. 222)
\end{abstract}

\title{
Plissagens e fissuras do qualquer
}

Cada tempo de verbo tem um sentido diverso - disse Neville. Existe ordem neste mundo; há distinções, há diferenças neste mundo, em cuja margem caminho. Pois isto é apenas um começo.

Virgínia Woolf

Desta vez, ele estava estendido sobre cacos de vidro. Digo ele, porque embora seu formato e certas determinações pudessem estabelecer tratar-se do gênero feminino, o que prevalecia ali era anterior... ou posterior... era um corpo. Deitado sobre pedaços simetricamente cortados em pequenos retângulos: vidros - jateados, espelhados, esverdeados e transparentes - aquele corpo convulsionava. Por vezes ininterruptamente, acompanhando uma seqüencia sonora contundente, sucessão de tiros, disparos subseqüentes. E então os disparos seguiam e o corpo se cansava, parava. Os olhos, sempre abertos, compunham um rosto inexpressivo. Uma lâmpada fosforescente baixada do teto punha-se a aumentar sua intensidade e abria clarões: brancos que interrogavam o corpo. E ele nada respondia. Sequer sentia-se convocado. Um corpo que desistiu de nada. De quando em quando, dois holofotes acendiam-se e cruzavam o espaço, numa espécie de ronda. 
Vibravam todo o espaço outras sonoridades além da dos cacos que estalavam a cada convulsão daquele corpo. Vibravam sonoridades plenas, espécies de sinos graves, containeres em percussão, ouvidos pelo seu interior. Minutos e segundos transcorriam com certos sinais que marcavam sua passagem. Uma experimentação ${ }^{4}$ com o tempo através do corpo se dava ali. Mais uma - não menos importante -, num universo contemporâneo de muitas experimentações que exigem o corpo como suporte de uma arte que quer acontecer em estreita relação com a transitoriedade do tempo. Subitamente, aquele corpo se levanta e permanece sentado num banco próximo ao monte de cacos. Imóvel, nele não há espera alguma, quiçá nenhum desejo também... Mais um movimento abrupto e ele se põe em pé. Ereto, finca-se com os dedos e a planta no chão e segue em sucessivas desarticulações que instauram um estado de desequilibrio vertiginoso e paradoxalmente estável até que se retira da sala. Possibilidade de aplauso não havia. Não houve espetáculo. $O$ que restou foi um vazio sem assombro. $O$ que tinha que ser feito, parecia ter sido feito. Nada de acrobacias, nada de sentimentos espremidos de uma suposta interioridade, nada de perfectibilidade técnica. Nada. E todos os outros corpos presentes, pouco a pouco, se retiraram dali onde, de algum modo, estiveram em comum.

Talvez o corpo fosse o melhor elemento de referência para designar cada quem deste escrito: corpo de um, corpo de dois, de três, corpos de alguns e de muitos, dispostos em conjunto para uma situação. Corpo - lugar onde algo se realiza e

4 Disposições Transitórias ou Pequenas Mortes, concepção, direção e performance de Vera Sala, em cartaz de 02/06 a 08/07 de 2007 na Unidade Provisória do SESC Avenida Paulista. Segundo o texto do material de divulgação, "o espetáculo investiga a ideia de rastros, daquilo que nos fornece indícios dos procedimentos vivenciados no corpo, e de como esses vestígios, ao serem redimensionados, promovem novas leituras e novas conexões nesse corpo.” A proposta do evento seria então "pensar o corpo em movimento como variações de configurações de estados corporais $[\ldots]$ ".." 
no qual o homem apreende sua finitude indeterminada. Seja o corpo uma grandeza aqui adotada, as operações se dão então ao acompanhá-lo em seus desfiles, em sua prontidão para travessias, percursos sem finalidade senão a do próprio poder percorrer, tomado como um sinal vital, tal qual na medicina: TPRP (temperatura, pressão, respiração e pulso), mais a dor... Sinais que indicam que se está vivo. Contados, descritos e inventados, a partir de experiências coletivas, lembradas tanto quanto esquecidas, em corpos, muitos personagensprotagonistas emergem neste texto, e as distâncias, entre suas supostas realidades de partida e suas presenças ficcionadas nas narrativas em que aqui aparecem, pouco poderão discriminar-se, restando ao leitor uma espécie de fé suspensa, uma confiança no que pode haver de importante nesta zona de indeterminação verossímil, que não evoca nem desdenha da verdade, mas que a supõe em microaparições, em sutilezas.

Para escrever com estas distâncias, a estratégia é pensar as figuras e apresentá-las no âmbito de sua eventualidade comum, naquilo que as alinha temporariamente. Várias narrativas se mostram em experimentos e, em todas elas, de algum modo, seja num tempo, num espaço, num projeto e/ou num fazer, há corpos em coexistência.

A partir desta sincronia, esta condição efêmera de se estar em comum, interessa pensar cada um, cada quem, tomado como o qualquer proposto por Agamben enquanto "o ser tal que, seja qual seja, ele importa" (AGAMBEN, 2006, p. 11) ${ }^{5}$ - o ser tal que de todo modo ele importe.

Furtiva e aparentemente contraditória, esta enunciação de Agamben, à primeira vista, confronta uma posição de indiferença [qualquer] e uma outra de distinção [que importe], o

5 Na sequência deste trecho Agamben comenta: "A tradução habitual no sentido de "não importa qual, indiferentemente" é desde logo correta, mas formalmente diz justo o contrário do latim: quodlibet ens não é "o ser, não importa qual”, senão "o ser tal que, seja qual seja, importa" [...]." 
que a tornaria insustentável. Entretanto, numa outra leitura, entrevê-se nesta formulação a aposta numa espécie de impessoalidade como elemento de diferenciação vital e suficiente, explicitada quando "a singularidade renuncia ao falso dilema que depreende o conhecimento a escolher entre o inefável do indivíduo e a inteligibilidade do universal". Nesta acepção, o qualquer prescinde das qualificações e especificidades para determinar sua importância. Este qualquer migra seu entendimento para o qualquer um, que seria um outro modo, não homogeneizante e diferenciante, de dizer que são 'todos', cada um singularmente, sem depender de propriedades ordinárias ou extraordinárias: ser qualquer um seria então suficiente para ser importante.

[...] se é verdade que o ser qualquer tem sempre um caráter potencial, ele é igualmente alguém que não tem potência de tal ou tal ato específico; ele não é mais, portanto, simplesmente incapaz, privado de potência, nem mesmo capaz de qualquer coisa indiferentemente, todo-poderoso: propriamente, qualquer é o ser que pode não ser, que pode sua própria impotência. (AGAMBEN, 2006, p. 35)

Entre a potência do nada e a do super, entre poder ser e igualmente poder não ser, estaria a singularidade qualquer e, em conjunto, os quaisquer. Quaisquer, num intervalo, num espaço vago que quando em conexão podem maquinar um evento: algo significativo, de difícil explicitação, justamente por tratar-se de uma faísca súbita, uma constelação inesperada de heterogêneos não sabidos de antemão, invisíveis à manipulação voluntária. Estão provavelmente na condição paradoxal de abulia e prontidão, à espreita tanto para o aniquilamento quanto para a efetuação vital, raramente previsíveis.

Muita vez, gestos e atitudes que se inscrevem num universo de combinatórias com elementos banais apresentam uma vitalidade fugidia ausente em outros mundos em que se reúnem elementos muito diversificados e não se opera com eles 
nenhuma combinação efetiva, deixando-os alinhados sem contato, sem ligação. Neste caso, a diversidade corresponde apenas à exigência de apresentar características visíveis tomadas como diferença, entretanto esta multiplicação de traços identificatórios não se agenciam e mantém-se em conjuntos forjados, que dificilmente alcançam uma existência comum. É uma espécie de império do Um, em que o múltiplo surge apenas como seu contraponto. No discurso mais corrente vê-se: múltiplas raças, múltiplas opções sexuais, múltiplas condições físicas, tudo designado sob a insígnia da diferença, diante da qual, em geral, apenas se despertam a compaixão e a tolerância, como afetos mediadores das relações nestes conjuntos.

O signo da multiplicidade ${ }^{6}$ deve então ser entendido como uma outra concepção, capaz de desertar as relações dicotômicas do uno e do múltiplo que pautam mudanças espaciais que não configuram viagens, encontros para não se encontrar. A multiplicidade, por sutis deslocamentos, interroga as polaridades do uno e do múltiplo, para desmontar um modo enrijecido de percepção da diferença e de relação com ela. Retoma-se a preceptiva de algo a se conhecer de um modo e num lugar intervalar, não previsto. Conhecer num lugar suspenso que, subitamente, se efetua em função do agenciamento de elementos heterogêneos visíveis, mas também - e em sua maioria - invisíveis, que constituem um cognoscível que não se adquire : um entendimento que advém do comum, daquilo que se dá a conhecer a qualquer um num coletivo e que permanece pertencente à esfera não palpável destes conjuntos. Para efeito exemplar, em trajetos pela multiplicidade dos mundos, algumas situações cotidianas sobressaem-se, nubladas, à minha memória.

6 Cf. "O verdadeiro substantivo, a própria substância é "multiplicidade", que torna inútil o uno, mas também o múltiplo. A multiplicidade variável é o quanto, o como, o a cada caso. Cada coisa é uma multiplicidade na medida em que encarna a Ideia." (DELEUZE, 1988, p. 260) 
Encontro alguém que me conta de alguns trajetos de ônibus: este parece ser o seu oficio não declarado, sequer reconhecido. Dirige-se a diferentes terminais da cidade, escolhe um número ou um conjunto de letras em posições diferentes (pois não sabe ler), às vezes pergunta pela sonoridade daquilo que sabe ser um nome de lugar, se acomoda num dos bancos e ali fica até que o veículo retorne ao ponto de partida. Em muitas ocasiões, dorme durante o percurso. Baba e ronca no banco e é chamado pelo cobrador. Em outras, é obrigado a descer, e tomar outro carro para a volta. (Em geral, sobe no mesmo, caso não hajam filas.) Não se perde, também não tem esta preocupação. Volta pra casa, passa um tempo, junta dinheiro, volta ao ponto.

Encontro outros alguéns. Estão num trem de luxo em plena Cordilheira dos Andes. Do lado de fora do vidro, moças e moços com pernas gordas e pele seca e queimada dançam em trajes coloridos. Logo na entrada do comboio, são oferecidas toalhas úmidas para limpar as mãos. Assepsia. Estão todos com roupas de algodão cáqui, adotadas de uma moda padronizada para "aventuras exóticas". Estão em férias, e o objetivo é a diversão instrutiva, formadora de cultura. Pagaram muito caro pela passagem que dá direito a um pageamento especial no trajeto externo: guias brancos engraçadinhos que distraem a todos das mínimas adversidades (nomes em língua estrangeira, cheiros de alimentos típicos) garantindo o bem-estar do trajeto, em que ninguém sofre riscos de perder-se: nem do caminho, menos ainda de si mesmo. No vagão traseiro, nativos tocam e cantam num bar com ares 'típicos da cultura local'. Tudo muito seguro e limpo. Garantia de ir e voltar sem sequer despentearse. Felizes, no vagão climatizado, falam inglês, contabilizam os lugares conhecidos e as informações recebidas e coletadas, riem alto e fotografam tudo pela janela cerrada. 
Mais um alguém. Pelas ruas em volta de sua casa, ele me guia. Apresenta lugares sempre vistos, sob detalhes pouco percebidos, menos ainda destacados como índices relevantes: os vários restaurantes - por quilo, churrascarias, rodízio de pizza, prato feito; dois supermercados - as diferenças de preço conforme o dia da semana, as qualidades de peixes e de frutas, o tamanho das filas em determinados horários, os doces já comprados, os já consumidos; a cor do invólucro de um bolinho; o número de quarteirões; os programas da televisão; os estabelecimentos abertos, os falidos, os trocados; e um sem cessar de pormenores que vão e vem subtraindo-se $e$ acrescentando-se. De repente silencia e organiza direções: o prato, os talheres, o lugar de atravessar, a porta por onde entrar, o corredor a seguir, a pausa para o café. Um território aparentemente restrito, mapeado à minúcia e com um sem fim de elementos a somar em sua geografia permanentemente móvel.

Em que coordenada espaço-temporal se poderia apreender a multiplicidade, e verificar sua distância em relação à diversidade ou à simples variação de elementos unitários? Onde estaria a viagem das diferenças diferençantes? Talvez, no deslocamento que não implicasse quilometragens mensuráveis, considerando que, numa multiplicidade não há unidades possíveis.

Só a categoria de multiplicidade, empregada como substantivo, e superando tanto o múltiplo como o Uno, superando a relação predicativa do Uno e do múltiplo, é capaz de explicar a produção desejante: a produção desejante é multiplicidade pura, quer dizer, afirmação irredutível à unidade. Estamos na idade dos objetos parciais, dos tijolos e dos restos. Já não acreditamos nesses falsos fragmentos que, como os pedaços de uma estátua antiga, esperam vir a ser completados e reunidos para comporem uma unidade que é também, a unidade de origem. Já não acreditamos numa totalidade original nem sequer numa totalidade final. [...] Só acreditamos em totalidades ao lado. E se encontrarmos uma totalidade ao lado das partes, ela será o todo dessas partes, mas que não as totaliza, uma unidade 
de todas essas partes, mas que não as unifica, e que se lhes junta como uma nova parte composta à parte. (DELEUZE; GUATTARI, 1966, p. 45)

Sem que haja aspiração à totalidade, o desejo - fluxo e corte -, seria este modo de operação pela multiplicidade em que se agenciam uma máquina acoplada à outra: enquanto uma flui a outra faz cortes. "É que há sempre uma máquina produtora de um fluxo e uma outra que se lhe une, realizando um corte, uma extração de fluxos" (DELEUZE; GUATTARI, 1966, p. 11). Desta compreensão do desejo, fora da chave do individual totalizado, trabalhada por Deleuze e Guattari, decorre pensar que o estar-junto implique desejar estar junto, mas não num registro voluntarioso, senão numa disponibilidade e confiança efêmera com um mundo que, de modo fragmentário, coloca e deixa colocar-se ao lado os elementos de alteridade.

Subitamente, alguns alguém se vêem juntos. E repetem este conjunto, repetem, repetem, repetem. De repente, não mais repetem. Cortam. E se acoplam a outros conjuntos, numa potencial deambulação. $\mathrm{E}$, se o corpo é o veículo desta deambulação, destes passeios de virtuais para os encontros e acontecimentos na multiplicidade de mundos que nos inundam, cabe retomar a acepção do qualquer para afirmar a potência de uma impessoalidade, de uma dessubjetivação que não procede necessariamente pela dissolução do $e u$, mas pela constituição de modos de funcionamento em que se possa prescindir do eu.

O homem qualquer, pressuposto aqui para a experiência de estar em comum, aponta para esta direção que interessa à clínica, no sentido de uma abordagem desinvestida das unidades de $e u$, em que se opera por estratégias de funcionamento conjunto nas quais, havendo ou não havendo um eu constituído, algo se passa em gestos coletivos que se qualificam pela presença em multiplicidade. Há lugares distintos para qualquer cada um, mas estes lugares só existem enquanto dura a presença 
daquele que o ocupa, e na ausência daquele, não há mais aquele lugar, e portanto não se configuram faltas. $\mathrm{O}$ que fica é nada. Não porque o que houvesse fosse desprovido de significação, mas porque o funcionamento na multiplicidade não encontra-se nas unidades, não é "cada um no seu quadrado" ou "cada um com seus problemas", e portanto as marcas produzidas são comuns, não situam-se em separado, ficam para o comum.

É evidente que esta é uma exploração escrita de uma política que se engendra em relações muito paradoxais, sobretudo porque a vontade de eu é um resquício moderno ainda reincidente na subjetividade contemporânea. Entretanto, é preciso pensar e afirmar este pensamento numa outra direção, para fortalecer traços éticos importantes que concorram para um deslocamento no cuidado e na delicadeza de se estar em presença comum, de se estar junto: na clínica e no mundo. A Teoria do Bloom parece corroborar com a complexificação destes entendimentos.

O Bloom é a negação mascarada. É por isto que seria absurdo celebrar sua aparição na história como o nascimento de um tipo humano particular: o homem sem qualidade não é uma certa qualidade de homem, mas ao contrário, o homem enquanto homem. A falha de identidade própria, a abstração de todo meio substancial, a falta de determinação "natural", longe de atribuir qualquer particularidade, o designa como a realização da essência humana genérica, que é precisamente privação de essência, pura exposição e pura disponibilidade. Sujeito sem subjetividade, pessoa sem personalidade, indivíduo sem individualidade, o Bloom faz explodir, ao seu simples contato, todas as velhas quimeras da metafísica tradicional, toda a quinquilharia enrijecida do eu transcendental e da unidade sintética da percepção. O que quer que se diga deste hóspede estranho que nos habita e que 
somos fatalmente, atinge-se o Ser. Aí, tudo se desvanece. ${ }^{7}$ (TIQQUN 1, 2001, p. 25)

Esta paulatina constelação de mundos em que o poder de dizer $e u$ tem sua potência enfraquecida, tornada desnecessária, para o bem e para o mal, avulta a experiência do impessoal, cuja possibilidade é, por um lado, a de livrar-se do peso do $e u$, corpo total, e daí poder paradoxalmente tornar-se o que se é, fora de uma espessura individual a ser inflada, carregada e defendida, possível num corpo fragmentário, provisório, mutante $\mathrm{e}$ migrante. Por outro lado, viver esta impessoalidade é também a ameaça do aniquilamento, do não ser, do ser nada, terror de não mais existir, de ver-se exilado de si mesmo, sem nada que lhe pertença individualmente.

Encontramo-nos num ponto de instabilidade no qual aqueles que atravessam e delineiam as constelações clínicas e políticas aqui presentes (sejam dispositivos, programas e/ou estabelecimentos) buscam operar suas vidas, estrangeiros a elas mesmas. A partir dos sinais desta espécie de supressão do eu é que designamos como qualquer ao elemento que se encontra nestas travessias, para acompanhá-lo em sua deambulação, que ocorre pelas bordas (uma vez tomado o centro como sendo os lugares de maior adesão ao funcionamento social hegemônico), num trânsito impessoal-importante, com distâncias que evidenciam a maquinação de outras políticas, com duração e interrupções singulares. Esta paisagem, assim descrita, numa

7 Trad. livre do trecho: “Le Bloom est le néant masqué. C'est pourquoi il serait absurde de célébrer son apparition dans l'histoire comme la naissance d'un type humain particulier: l'homme sans qualité n'est pas une certaine qualité d'homme, mais au contraire l'homme en tant qu 'homme. Le défaut d'identité propre, l'abstraction de tout milieu substantiel, l'absence de détermination «naturelle», loin de l'assigner à une quelconque particularité, le désignent comme la réalisation de l'essence humaine générique, qui est précisément privation d'essence, pure exposition et pure disponibilité. Sujet sans subjectivité, personne sans personnalité, individu sans individualité, le Bloom fait exploser à son simple contact toutes les vieilles chimères de la métaphysique traditionnelle, toute la quincaillerie figée du moi transcendantal et de l'unité synthétique de l'aperception. Quoi que l'on dise de cet hôte étrange qui nous habite et que nous sommes fatalement, on atteint à l'Etre. Là, tout s'évanouit." 
visualização evanescente e impalpável, é a atmosfera do estar em comum, com as interrogações que decorrem deste estado.

Se, por outro lado, chamamos Comum o ponto de indiferença entre o próprio e o impróprio, isto é, qualquer coisa que não pode jamais ser apreendida em termos de apropriação ou expropriação, mas somente como uso, então o problema político essencial torna-se: "como fazer uso do comum"[...] (AGAMBEN, 2002b, p.130).

Desafiamo-nos neste fluxo a pensar por ajuntamentos, a escrever de uma clínica de modo a extirpar a lógica das individualidades em favor das singularidades. É por isto que são adotados estes deslocamentos que permitem abordagens não mais a partir de indivíduos o que, no campo clínico tem sido pensado sob muitas perspectivas. Destas, destacamos a teoria dos processos de individuação, de Gilbert Simondon, que sustenta uma condição contínua da processualidade, e não visa ao indivíduo constituído, final. Esta abordagem dialoga com certa vertente de escritos e pesquisas em filosofia e ciências humanas, bem como em biologia e neurociências que têm fomentado modos de pensar atuais. Dar destaque a esta concepção importa aqui a fim de retomar a necessidade de pautar o trabalho com grupos humanos sob o regime de multiplicidade, abolindo a referência à unidade e ao múltiplo. Assim entendida, a operação de individuar-se a que todos estaríamos submetidos introduz uma perspectiva que impede estabelecimentos, no sentido de corroborar para a desmontagem do pensamento pautado no surgimento de um eu fechado numa identidade permanente ou essencial, enquanto finalidade existencial. Isto embaralha noções tais como as de completude, de preenchimento e de totalidade, hegemônicas no campo psicológico. Grosso modo, neste outro regime de pensamento, a 
própria noção de heterogeneidade se vê interrogada e com ela o par dicotômico inclusão-exclusão.

Uma vez que, por exemplo, uma configuração é definida apenas em função da presença de uma pessoa que se reconheça como da raça negra, uma pessoa com uma deficiência e uma pessoa que se declare homossexual, temos um conjunto de universais, que nos deixa, provavelmente, impedidos de nos ver diante de uma multiplicidade. A diferença diferençante, como vimos afirmando, não se reconhece na multiplicação de marcas identitárias pois, vistas assim, elas sempre fariam parte daquilo que foi instituído historicamente, sendo denominadas segundo critérios socialmente preponderantes, e portanto não expressando nenhuma exterioridade que as distinga, permanecendo homogêneas em relação a estas marcas evidentes. A radical heterogeneidade estaria em poder deixar vir, mesmo dentro de um conjunto de elementos aparentemente idênticos do ponto de vista dos códigos vigentes, as sutis diferenças, posições singulares provisórias e ligações consigo e com outrem, que sejam marcas da resistência aos enquadramentos identitários das formas de poder universalizantes. Busca-se menos por indivíduos, mais por processos vitais sempre em vias de produzir um si mesmo singular, qualquer e não específico, genérico e não universal.

As ações e intervenções da clínica e, em extensão, a de alguns territórios afins - como o da educação -, ficam assim convocadas a efetivarem relações de multiplicidade contemplando a efemeridade da vida, em seu percurso metaestável de formas que se compõem, se justapõem e estabilizam-se temporariamente, até que se submetam a novos atravessamentos e sejam forçadas a adquirir outras configurações. Este pensamento está bastante investigado por Simondon, em seu trabalho L'individu et sa genèse physicobiologique, cuja proposta se compõe a partir de uma inversão: "conhecer o indivíduo pela individuação muito mais do que a 
individuação a partir do indivíduo" (SIMONDON, 2003, p. 100). A relevância desta reviravolta está na possibilidade de não supor o indivíduo como resultado, finalidade de um processo, mas como atravessamento deste, produção derivada, em meio a outras produções concomitantes e incompossíveis.

[...] o indivíduo seria apresentado como uma realidade relativa, uma determinada fase do ser que supõe uma realidade pré-individual anterior a ela, e que não existe completamente só, mesmo depois da individuação, pois a individuação não esgota de uma única vez os potenciais da realidade pré-individual; por outro lado, o que a individuação faz aparecer é não só o indivíduo mas também o par indivíduo-meio". (SIMONDON, 2003, p.100-1)

É preciso ressaltar que esse par indivíduo-meio deve ser tomado como um dualismo proposto a fim de afirmar uma relação de agenciamento, de articulação entre dimensões, em lugar de pensar numa relação de oposição. Mais ainda, interessa nesta concepção de Simondon perceber que o processo de individuação não culmina no aparecimento de um indivíduo exclusivo e isolado, mas, no mínimo, numa espécie de composição com o entorno, que prossegue oferecendo potenciais de realidade para sua individuação, que é também seu processo de alteridade: ser outro em relação àquilo que afeta para ser um. Devir por intermédio de outrem (não só sujeitos mas também dispositivos, percepções e objetos materiais) e fazer outrem devir por intermédio de mim.

Uma outra concepção fortalecedora desta visada que deserta a totalidade do eu, encontra-se nos estudos de Deleuze feitos a partir da obra de Foucault, em que se enunciam processos de subjetivação, a constituição das relações de si para consigo, para o cuidado de si, para uma "existência estética". Como fórmula geral, são elencadas "quatro dobras", variáveis e constituintes de "modos irredutíveis de subjetivação".

A primeira concerne à parte material de nós mesmos que vai ser cercada, presa na dobra: para os gregos, era o corpo e seus prazeres, os aphrodisia; mas para os cristãos, será a 
carne e seus desejos, o desejo, uma modalidade substancial completamente diferente. A segunda dobra é a relação de forças, no seu sentido mais exato; pois é sempre segundo uma regra singular que a relação de forças é vergada para tornar-se relação consigo; certamente não é a mesma coisa quando a regra eficiente é natural, ou divina, ou racional, ou estética... A terceira dobra é a do saber, ou a dobra da verdade, por constituir uma ligação do verdadeiro com o nosso ser, e de nosso ser com a verdade, que servirá de condição formal para todo saber, para todo conhecimento: subjetivação do saber que não se faz da mesma maneira entre os gregos e entre os cristãos, em Platão, Descartes ou Kant. A quarta dobra é o próprio lado de fora, a última: é ela que constitui o que Blanchot chamava uma "interioridade de espera", é dela que o sujeito espera, de diversos modos, a imortalidade, ou a eternidade, a salvação, a liberdade, a morte, o desprendimento... (DELEUZE,1988, p.111-2.)

Destas plissagens, a última, a dobra que é “o próprio lado de fora", converge ainda mais para a noção do qualquer na medida em que se pode pensar que, num processo de subjetivação, a dimensão de interioridade não se aloja num dentro fechado, mas no próprio exterior. Este parece ser um elemento de força dessa impessoalidade que tentamos abordar neste estudo, pois estando do lado de fora é possível resistir à sujeição - seja ela a da individualização controladora e geradora de dependências que é instaurada pelo poder hegemônico na vida cotidiana, seja a do apego a uma identidade fixada e codificada pelas técnicas da ciência e seu consequente saber sobre o sujeito. Nesta "interioridade de espera", o sujeito está aberto ao acaso, com os deslocamentos e as fissuras que um acontecimento pode comportar.

A ideia de uma unidade sujeito, assim como a de uma unidade indivíduo, - com Simondon, Deleuze, Foucault e Blanchot -, são postas em movimento, em mutação. Impedido de operar por estas unidades, o pensamento se instaura em outras relações, e passa a ser convocado a experimentar, a problematizar sem constituir saberes estanques e previstos, modulando-se ao limite, ao acaso. 
Neville, Rhoda, Bernard, Susan, Jinny, Louis são singularidades experimentadas por Virgínia Woolf que se propõe a acompanhá-las em movimentos de fluxos e refluxos, misturas e distinções de onde surge As Ondas, um livro sem história, com muitas pequenas histórias, com várias histórias todas que não formam uma... Quase não há um livro.

Como são raramente visitados nossos amigos, pouco conhecidos - é verdade; e ainda assim, quando encontro um desconhecido, e tento expor, aqui nesta mesa, o que chamo de "minha vida", não é para uma vida que olho, ao recordar; não sou uma pessoa; sou muitas; não sei bem quem sou Jinny, Susan, Neville, Rhoda ou Louis - nem como distinguir minha vida das suas. (WOOLF, 2004, p.207)

Esse modo de narrar através de fluxos e singularidades, radicaliza a experiência de uma existência comum. As figuras se destacam em ondas, literalmente, em frases e parágrafos que se misturam e que se diferenciam sutilmente. Ao escrever assim, considera Blanchot, a escritora é lançada numa espécie de zona de perigo, num lugar de risco que serviria como elemento para responder à indagação sobre a contraditória necessidade de uma outra escrita, concomitante na vida desta autora, a escrita dos diários.

Sábado, 7 de fevereiro [de 1931]

Aqui nos poucos minutos que restam, devo registrar, com a graça divina, o fim de As Ondas. Escrevi as palavras Oh Morte há quinze minutos, após ter recitado de enfiada as últimas dez páginas com alguns momentos de tamanha intensidade \& arrebatamento que eu parecia perseguir hesitante minha própria voz, ou quase, perseguir algum orador (como quando estive louca). Quase tive medo, lembrando-me das vozes que costumavam se precipitar à minha frente. Em todo caso, está acabado; \& passei estes 15 minutos em um estado de glória, \& calma, \& algumas lágrimas, pensando em Thoby \& se pudesse escrever Julian Thoby Stephen 1881-1906 na primeira página. Presumo que não. Quão física a sensação de triunfo \& alívio! Se bom ou ruim, está acabado; \& como decerto senti no fim, não somente terminado, mas consumado, inteiro, a coisa formulada - quão apressadamente, quão fragmentariamente eu sei; mas quero dizer que apanhei na rede aquela barbatana na imensidão das águas que me surgiu sobre os pântanos a minha janela [...] (WOOLF, 1989, p.186) 
Diários íntimos, símbolo de um eu erigido, imperativo. Blanchot questiona a necessidade concomitante destas duas escritas: a dos diários sob a figura do eu unitário e a da obra fragmentária com figuras de impessoalidade. Isto é exemplar e poético na corrente deste estudo, no sentido de que esta aproximação com o comum, e por conseguinte com o qualquer tal qual estamos trabalhando, prescindindo da noção de $e u$ nas operações do pensar e do agir, podem ter efeitos reversos, de recrudescimento diante do desespero do aniquilamento, resultando num forte apego às representações mais estereotipadas desta suposta interioridade totalizada.

Mas que um escritor tão puro quanto Virgínia Woolf, que uma artista tão empenhada em criar uma obra que retivesse somente a transparência, a auréola luminosa e os leves contornos das coisas, tenha se sentido de certa maneira obrigada a voltar-se para junto de si, num diário tagarela em que o Eu se derrama e se consola, isso é significativo e perturbador. O diário aparece aqui como uma proteção contra a loucura, contra o perigo da escrita. Lá, em As Ondas, ruge o risco de uma obra em que é preciso desaparecer. Lá no espaço da obra, tudo se perde e talvez a própria obra se perca. O diário é a âncora que raspa o fundo do cotidiano e se agarra às asperezas da vaidade. (BLANCHOT, 2005, p. 273)

Talvez, os experimentos em narrativas deste escrito, guardem relação com este território de risco. De início, as situações vivenciadas são mote para uma produção que quer perceber a importância de um comum efêmero, bem como, posteriormente, a proposição de um desobramento como política potencial deste comum. Entretanto, concomitantemente à necessidade de transformar estas vivências num escrito, pode haver uma operação intrínseca de exibição de um suposto eu que esteve ali, erigindo uma terapeuta ideal, ou uma escritora monumental. Difícil sair desta posição de arrogar-se escrever e simultaneamente retirar-se da escrita, deixar que nela se potencialize o impessoal e as singularidades, num processo de despersonalização. Saída provisória é pensar que se o escritor se faz na busca, conforme o denomina Blanchot, do mesmo modo 
pode-se pensar o terapeuta, e o terapeuta-autor, como aquele que só existe no instante em que quer tornar obra, o outro, sua obra interminável, sempre por vir, impossível obra...

As obras deveriam pois ser o mais importante. Mas será assim? De modo algum. O que atrai o escritor, o que impulsiona o artista não é diretamente a obra, é sua busca, o movimento que conduz a ela, a aproximação que torna a obra possível: a arte, a literatura e o que essas duas palavras dissimulam. Por isto um pintor, a um quadro, prefere os diversos estados deste quadro. E o escritor, frequentemente, não deseja acabar quase nada, deixando em estado de fragmentos cem narrativas que tiveram a função de conduzilo a determinado ponto, e que ele deve abandonar para tentar ir além desse ponto. Daí, por uma coincidência novamente espantosa, Valéry e Kafka, separados por quase tudo, próximos apenas pelo cuidado de escrever rigorosamente, juntam-se para afirmar: "Toda a minha obra é apenas um exercício.” (BLANCHOT, 2005, p. 291)

Aparentemente irresolúvel, este exercício de dar a conhecer modos de funcionar no comum, e de simultaneamente fazer o esforço por não destacar-se nesta exposição, permite insistir na migração da noção de indivíduo à de singularidades, operando não mais por identidades, mas por exterioridades, na tentativa de transformar a própria concepção do pensar, deslocando-se de uma atitude de elencar princípios para movimentos de diferenciação e afirmação da vida em suas conexões singulares. ${ }^{8}$

8 INFORSATO, Erika Alvarez. Clínica Barroca - exercícios de simpatia e feitiçaria. (Dissertação). Mestrado em Psicologia Clínica. São Paulo, PUC-SP, março de 2005. Este estudo consistiu num exercício crítico na clínica com alguns operadores conceituais da filosofia, a partir da leitura da obra de Leibniz feita por Deleuze. A noção de 'barroco,' enquanto 'dobra que vai ao infinito', foi transversalizada em alguns acontecimentos-situações clínicas - relatados a partir de experiências com pacientes graves que prosseguiram, e são ainda matéria desta pesquisa (uma companhia de teatro; um serviço de terapia ocupacional e suas parcerias com projetos na fronteira entre as artes e a clínica; e trabalhos de acompanhamento terapêutico). No decurso da dissertação, busquei tornar este conceito heteróclito do "barroco", aportado por Deleuze, como um dispositivo de problematização de temas como a inclusão, a monstruosidade, a adaptação, a caridade e a crueldade. As noções de simpatia e feitiçaria advindas da literatura apareceram como intercessores nestas relações ao apontar saídas para uma experimentação da clínica desinvestida de suas configurações convencionadas. Foram usados, para tanto, estudos do campo das artes, mas, principalmente, conceitos da filosofia de Deleuze e Guattari para composição de um território crítico que teria por função reativar o compromisso da clínica com a criação, interessada não na proliferação de princípios do barroco, mas na multiplicidade 
E é isto o lado de fora: a linha que não pára de reencadear as extrações, feitas ao acaso, em mistos de aleatório e de dependência. Pensar assume aqui, então, novas figuras: obter singularidades; reencadear as extrações, os sorteios; e inventar, a cada vez, as séries que vão da vizinhança de uma singularidade à vizinhança de outra. (DELEUZE, 1988, p.125.)

Este deslocamento do pensar pode pautar-se sobre a noção de dobra, enquanto aquilo que varia infinitamente em decorrência de elementos e universos infinitos, conforme as aproximações, ultrapassamentos e digressões de Gilles Deleuze ao pensamento de Leibniz. Por intermédio das singularidades, e para desertar as prescrições, os métodos, os princípios e os regramentos, bem como a jurisprudência que, supostamente, seriam os parâmetros orientadores do decorrer da vida, adota-se a ideia de uma afirmação diferencial da vida, extraída dos escritos de Deleuze, como uma proposição que permita que a simples experiência do viver (do estar-se vivo) seja a referência soberana para a própria vida. Na esteira de uma dessubjetivação, conforme vimos afirmando, associada à proposição do qualquer, verifica-se que além de estar vivo não é preciso mais nada, não são necessárias nenhuma qualificação, e todas as particularidades são prescindíveis. O que não torna nada nem ninguém desinteressantes. Ao contrário, o conhecimento deste outrem singular qualquer torna-se mais instigante na medida em que são seus movimentos, seus modos de agir e de fazer gestos no mundo, que agregam e desagregam conjuntos, o que passa a motivar a curiosidade por conhecê-lo.

A noção de simpatia, encontrada em Deleuze, em apontamentos ao texto de D.H. Lawrence - Whitman -, enquanto um conceito a compor uma orientação geral deste deslocamento reinveste-se para intensificar sua potência para relações de vida e de conhecimento.

Simpatia seria, inicialmente, uma região de sensações e entendimentos que, para efeito da pragmática do cotidiano, 
desdobra-se numa prática, num modo de fazer, através de projetos que pressupõem, no âmbito mais específico da clínica, cuidar de alguém que está em situação de sofrimento intenso, com riscos de engessamento, anestesia e/ou paralisia. A simpatia, trazida à técnica de uma certa clínica, seria então um modo de convocar o pathos, a construção de um procedimento crítico e contemplativo de aproximação e conhecimento de outrem. Com isso, supõem-se uma prontidão aos encontros que constituem o cotidiano da clínica e de outras matérias que lidem com encontros humanos, em busca de uma convivialidade, um estar com, um querer estar com aquilo que pode provocar uma desterritorialização recíproca. Simpatia para alcançar forças que deslocam a todos em direção ao enriquecimento dos espíritos, não como espíritos elevados, mas mais mundanos - que cuidam e compõem com o mundo -, quase o humano essencial, fora das formatações restritivas do humano universal. Num dos trechos de Whitman, D.H Lawrence propõe a "estrada larga":

Estrada Larga. A grande casa da Alma é a estrada larga. Nem céu, nem paraíso. Nem "acima", nem mesmo "dentro". A alma não está "acima" nem "dentro". É um viandante a caminhar pela estrada larga.

Não pela meditação. Nem pelo jejum. Nem explorando céu após céu, interiormente, à maneira dos grandes místicos. Nem pela exaltação. Nem pelo êxtase. Não é por nenhum destes caminhos que a alma se preenche.

Mas só fazendo-se à estrada larga.

Não através da caridade, nem do sacrifício. Nem mesmo do amor. Não através das boas obras. Não é assim que a alma se realiza.

Mas só através da viagem pela estrada larga. Da viagem em si mesma, pela estrada larga. Exposta a todos os contatos. Em dois lentos pés. Cruzando-se com tudo o que venha pela estrada larga. Na companhia dos que vogam ao mesmo compasso, pelo mesmo caminho. Para nenhum destino. Sempre a estrada larga.

Não tendo sequer direção conhecida. Permanecendo a alma apenas fiel no trajeto a si mesma.

Cruzando-se na estrada com todos os outros viandantes. E como? Como cruzar-se com eles, e como passar adiante? Com simpatia. Simpatia. Não diz amor. Diz simpatia. Sentir com, sentir em consonância com eles. (LAWRENCE, 1994, p. 25-6.) 
Para avançar sobre a ideia da simpatia, David Lapoujade relacionou esta noção à de conhecimento. Ele tomou a simpatia como uma experiência distinta de conhecimento, e com isto redefiniu a própria noção de conhecimento, questionando-a em sua forma convencional de conhecimento adquirido, ou seja, conhecimento daquilo que podemos prever, confirmação de um saber prévio, conhecimento que pré-existe e que aplicamos sobre a experiência, conhecimento que possuímos. (LAPOUJADE, 2009).

Para ele, um outro modo do conhecimento seria migratório ou deambulatório, um conhecimento que seria inalcançável, e que operaria pela simpatia, pelo exercício de acompanhar outrem nos movimentos que ele produz, e que nos interessam na medida em que são neles que se encontram os pequenos sinais secretos que fazem devir quem com eles simpatiza. Em sua proposição, ele acentua que não se trata de imitar outrem, mas de devir por intermédio de outrem, situar-se portanto no mesmo plano, encontrar-se no mesmo ritmo, afinarse na mesma tonalidade e, poderíamos acrescentar: estar em comum, para poder escutar, perceber e experimentar de qual lugar o outro fala, por qual perspectiva ele age e enuncia. É uma tentativa de sincronizar, um "acordo rítmico" que busca colocarse na mesma tonalidade afetiva, como "uma atividade espiritual, por excelência", e não menos pragmática por isto. Pois, esta afinação tonal resulta na constituição do que ele chama uma "linha deambulatória" que, mesmo que ziguezagueante, orienta por pequenos traçados, e "permite aos sinais discretos e aos segredos instaurar, fazer vir novas realidades.” (LAPOUJADE, 2009) A simpatia precisa, para tanto, livrar-se da imposição da forma homem, dessa humanidade que, segundo Lapoujade, projetamos por toda parte, e que faz com que a própria simpatia se confunda à compaixão. Apenas quando liberada dessa antropomorfização e deste antropocentrismo é que a simpatia pode ser associada ao conhecimento. 
Comprometer-se com esta simpatia que focaliza a questão de um outro modo de conhecer, transportável às questões da aprendizagem e às experiências advindas das intervenções clínicas, releva a experimentação ao status de uma tecnologia de exercício sobre si.

Para efeito deste estudo, a pauta que orienta seu pensamento, como já referido, são vivências em projetos que têm como ponto de partida a prática profissional em terapia ocupacional (TO), deles vem os "sinais secretos", índices estranhos que movem a vontade de saber, a necessidade de pensar. Se este marco inicial é a TO, a questão das atividades humanas fica relacionada aos processos de cura, tornando ainda mais relevante a abordagem dos temas da experimentação e da aprendizagem na chave deste outro conhecimento.

É habitual no campo da TO que a atividade seja colocada no centro da clínica de modo a estimular o terapeuta a observarse num papel de empreitar a vida alheia. Mesmo nas perspectivas humanistas (talvez, sobretudo nelas) as avaliações e abordagens dirigem-se a um investimento numa suposta subjetividade a ser constituída que, em geral, guarda marcas dos modelos hegemônicos. Dia-a-dia as demandas preestabelecidas para o profissional incluem questões complexas que vão desde o treinamento de tarefas cotidianas objetivas (comer, pegar ônibus, vestir-se, limpar a casa, que acabam por determinar e prescrever necessidades), bem como a comercialização das chamadas 'obras' (pinturas, desenhos, gravuras etc) - trabalhos feitos em ateliês e grupos de TO com intuito de inclusão social e geração de renda; além das questões de cidadania e direitos do homem que geram lutas massivas, com a marca inevitável da moral da boa vontade, da responsabilidade com o outro, do enfrentamento social, da criação de acessibilidade que, com 
intenções socialitárias ou comunitárias, acabam sob uma vigência autoritária para ambos: cuidador e cuidado.

Alguém coleciona papéis. Por onde passa pega um panfleto, uma revista, um encarte... Empilha todos no quarto, alguns com elementos mais evidentes de interesse: mulheres bonitas, brinquedos, fotos, letras coloridas... Outros sem nada aparentemente atrativo. Sua mãe chantageia, barganha com esta coleção: “- Não quer sair? Então vou jogar todos os seus papéis..." E os papéis vão mofando. E cada vez que a mãe tenta fazer uma seleção vem uma angústia, uma aflição imensa, são partes de si ameaçadas de serem separadas, jogadas ao lixo. Como fazer? Qual saúde está em risco?

Interrogado sobre quantos anos tem, um outro rapaz, cuja data de nascimento em seu registro acusa 24 anos, se diz com 6. “- Você precisa fazer coisas de gente grande!” No momento de contratar o acompanhamento terapêutico a proposta é de caminhar com ele em direção a uma atividade de trabalho, colocá-lo em relação com isto... A mãe nos conta que se ele trabalhar perde o benefício de invalidez. E ele, diz que quer brincar. Para onde vamos? Ao parque, jogar futebol, à oficina, ao computador, o que importa inserir nesta história?

O livro escolhido para emprestar a ela, outra figura atendida, é A hora da estrela, de Clarice Lispector. Ela lê e o devolve, cuidadosamente embrulhado num saquinho, no dia que não choveu. Ela interroga sobre por quê alguém precisa sofrer tanto numa história. Ela mesma tem uma vida de muito sofrimento, e imediatamente associa que o livro era para ela 'ver a vida dela'. Que foi isso? Vontade de oferecer a suposta boa literatura a alguém que não tem acesso fácil a isto? Imposição de gosto e de pensamento na vida de outrem? Intervenção especular? 
Trouxe um outro homem a foto de quando não tinha sofrido ainda o acidente vascular cerebral que o deixara hemiplégico. Estava no terraço da casa. Quis mostrar a todos. No momento do exercício corporal apavorou-se, fez que ia chorar, ficou rígido de pânico. A simples exigência de que ficasse em pé era demais para seus músculos fracos, acostumados a passar toda a semana entre a cama e o sofá. Não deixá-lo sentar, ele pedia até mesmo para deitar. Não deixar, para melhorá-lo? Melhor pra quê? De onde se sabe o que é melhor para si? E para outrem? A foto era de ontem ou era pra hoje já um seu modo de viver melhor?

Impasses: cada ponto de uma vida se compõe de outros tantos pontos - de interrogação -, que não podem emergir sempre, para não atravancá-la, e que no entanto também não podem submergir totalmente, para não automatizá-la. Aprendizagens e ensinamentos devem se dar, mas por onde e como? Provavelmente um estar-junto deve oferecer outras pistas. Mas quais experiências legitimam as intervenções considerando que a multiplicidade é o ponto de interesse e que não se trata de fortalecer os eus? $\mathrm{E}$ as empreitadas, essas alavancas vorazes que muitas vezes nos autorizamos acionar em relação à vida alheia, está referida em quê valores? Talvez haja uma briga com a ambivalência de não fazer nada e de nada fazer, entre o desejo de melhorar outrem e a percepção e a vontade de acompanhar sua estranheza... Vemo-nos diante da difícil disposição de sermos todos um qualquer e experimentar algo que pode passar-se nesta impessoalidade. Não é uma proposta de intervenção leviana, frouxa, mas uma tentativa de resistir às intervenções espetaculares, representativas, vistosas, prescritivas, que valem pontos nas rodas acadêmicas e governamentais. Para poder questionar as formas dadas sem vida e a vida genérica sem forma, além de outros elementos 
neste campo de tensões em relação à impossibilidade ou à possibilidade - e qual - da experiência, a Teoria do Bloom é evocada novamente.

O traço dominante do ethos espetacular metropolitano é a perda da experiência, da qual a formação da própria categoria da experiência, no sentido restrito em que se "têm experiências" (sexuais, esportivas, profissionais, artísticas, sentimentais, lúdicas etc) é certamente o sintoma mais eloquente. [...] No seio do Espetáculo, como da metrópole, os homens jamais têm a experiência dos acontecimentos concretos, mas somente das convenções, das regras, de uma segunda natureza inteiramente simbolizada, inteiramente construída. Reina aí uma cisão radical entre a insignificância da vida cotidiana, dita "privada", onde nada acontece, e a transcendência de uma história congelada numa esfera dita "pública", à qual ninguém tem acesso. Em outros termos, o que é representado jamais é vivido, enquanto que o que é vivido jamais é representado. Aí onde reina a alienação da Publicidade, onde os homens não podem mais se reconhecer uns aos outros como participantes da edificação de um mundo comum, aí reina também o Bloom. Nele, as profundezas do desastre manifestam a que ponto a perda da experiência e a perda da comunidade são uma única coisa, vista sob ângulos diferentes. Mas tudo isto pertence cada vez mais nitidamente à história passada. A separação entre as formas sem vida do Espetáculo e a "vida sem forma" do Bloom, com seu tédio monocromático e sua silenciosa sede de nada, cede, em numerosos pontos, lugar à indistinção. A perda da experiência alcançou enfim o grau de generalidade em que ela pode, por sua vez, ser interpretada como experiência fundamental, como experiência da experiência enquanto tal [...]. ${ }^{9}$ (TIQQUN 1, 2001, p. 27)

9 Trad. livre do trecho: "Le trait dominant de l'ethos spectaculaire-métropolitain est la perte de l'expérience, dont la formation de la catégorie même de l'«expérience» au sens restreint où l'on «a des expériences» (sexuelles, sportives, professionnelles, artistiques, sentimentales, ludiques, etc.), est certainement le symptôme le plus éloquent. Tout, dans le Bloom, découle de cette perte, ou en est synonyme. Au sein du Spectacle, comme de la métropole, les hommes ne font jamais l'expérience des événements concrets, mais seulement des conventions, des règles, d'une seconde nature entièrement symbolisée, entièrement construite. Il règne là une scission radicale entre 1 ' insignifiance de la vie quotidienne, dite «privée», où il ne se passe rien, et la transcendance d'une histoire congelée dans une sphère dite «publique», à laquelle nul n'a accès. En d'autres termes, ce qui est représenté n'est jamais vécu, tandis que ce qui est vécu n'est jamais représenté. Là où règne l'aliénation de la Publicité, là où les hommes ne peuvent plus se reconnaître les uns les autres comme participant à l'édification d'un monde commun, là règne aussi le Bloom. En lui, les profondeurs du désastre manifestent à quel point la perte de l'expérience et la perte de la communauté sont une seule chose, vue sous des angles différents. Mais tout cela relève de plus en plus nettement de l'histoire passée. La séparation entre les formes sans vie du Spectacle et la «vie sans forme» du Bloom, avec son ennui monochrome et sa silencieuse soif de néant, cède en de nombreux points la place à l' indistinction. La perte de l'expérience a enfin atteint le degré de généralité où elle peut à son tour être interprétée comme expérience fondamentale, comme expérience de l'expérience en tant que telle [...]." 
No ensejo de compor para o quadro crítico da experiência na contemporaneidade, outras vias de consideração podem incrementar o plano de conhecimento que interessa instaurar com este estudo. De modo pontual, vale elencar algumas destas direções a fim de legitimar a tessitura que dá consistência a este deslocamento do pensar e do conhecer às regiões de imprevisibilidade e de abertura.

A partir da apresentação de um conceito ampliado de cognição, a pesquisadora Virgínia Kastrup, em seu livro $A$ invenção de si e do mundo propõe uma política da invenção no lugar daquela da recognição, em que a importância do coletivo e da invenção de problemas são potencializadas, e mudanças no entendimento da eficácia nestes processos são propostas.

O melhor desempenho não é assegurado pelo domínio de uma técnica. A performance não é repetição mecânica, ela implica um agenciamento com fluxos, a aprendizagem sempre envolve devires aparalelos. A aprendizagem exige destreza no trato com o devir. Aprender é, antes de tudo, ser capaz de problematizar, ser sensível às variações materiais que têm lugar em nossa cognição presente. (KASTRUP, 1999, p. 151-2.)

Distinguir entre um processo de aprendizagem inventivo e outro pautado na recognição é, segundo Kastrup, um modo de resistir ao regime totalitário da subjetividade, apegado ao senso comum que interrompe a processualidade e triunfa eventualmente sobre as forças de criação.(KASTRUP, 1999, p. 158.) O que está em questão no trabalho de Kastrup é o achatamento que as separações postuladas pelas ciências modernas - entre sujeito e objeto, natureza e artifício, indivíduo e sociedade -, exerce sobre os modos de conhecer, excluindo toda a gama de conexões heterogêneas e os possíveis hibridismos.

Ao supor, de saída, que o agenciamento se faz no nível coletivo das multiplicidades, abre-se a possibilidade efetiva de pensar uma cognição híbrida [...] Sem ser individual ou social, humano ou técnico, mas uma zona de fronteira e 
mediação comunicante, o domínio dos agenciamentos faz um trabalho de hibridação, que responde pela invenção e reinvenção das formas cognitivas existentes. Falamos então em contato, passagem e transformação recíproca entre elementos heterogêneos, mecânicos, cognitivos, informacionais, políticos e sociais. Só assim se torna clara a ideia de uma cognição ao mesmo tempo heterogênea e heterogenética, híbrido de natureza e artifício, de indivíduo e sociedade. (KASTRUP, 1999, 189)

Associada a estes estudos de Kastrup em relação à importância da dimensão de invenção de problemas relacionada à cognição e, considerando a proposição apontada anteriormente, de David Lapoujade, de que, ao propor a simpatia em estreita relação com o conhecimento, a noção de conhecimento adquirido e possuído fica em xeque, faz-se necessário apontar uma outra referência, que dá substrato a estas ideias e consistência ao universo onde toda nossa pesquisa se engendra. Trata-se da abordagem da multiplicidade apresentada por Deleuze em sua obra Diferença e Repetição (1988) Neste estudo, as ideias são multiplicidades, são partes que colocam-se ao lado, sem constituir um todo ou algo supostamente inteiro. Uma vez tomado o próprio acaso como a dimensão de onde emergem as ideias, não seria a "essência", determinada por oposição entre o que é e o que não é, aquilo que caraterizaria um problema mas, ao contrário, seriam as condições adjacentes, o entorno do problema o que definiria sua importância - aquilo que Deleuze, a partir de Leibniz, chama de vicedicção.

\footnotetext{
Eis porque o procedimento da vicediç̧ão, próprio para percorrer e descrever as multiplicidades e os temas, é mais importante que o da contradição, que pretende determinar a essência e preservar sua simplicidade. [...] O problema do pensamento não está ligado à essência, mas à avaliação do que tem importância e do que não tem; está ligado à repartição do singular e do regular, do notável e do ordinário, repartição que se faz inteiramente no inessencial ou na descrição de uma multiplicidade, em relação aos acontecimentos ideais que constituem as condições de um "problema". (DELEUZE, 2006, p. 269)
}

Neste sentido, a aprendizagem é apresentada por Deleuze alinhando aprender com uma operação com a urgência dos 
problemas e saber com uma posse de regras para aplicação em forma de soluções.

Aprender é o nome que convém aos atos subjetivos operados em face da objetividade do problema (Ideia), ao passo que saber designa apenas a generalidade do conceito ou a calma posse de uma regra das soluções. (DELEUZE, 2006, p. 236.)

Torna-se importante, neste ponto, adensar o entendimento da noção de aprendizagem tal qual apareceu até aqui, como decorrência da possibilidade da experiência. Assim, sob uma outra perspectiva, que converge para aquelas abordadas até aqui, Walter Benjamin em seu texto Experiência e Pobreza (BENJAMIN, 1994, p. 114.) apresenta um quadro crítico da modernidade, de modo a demonstrar que a experiência não faz mais parte das aspirações do homem. Segundo o autor, aspira-se, sim, a prescindir qualquer nova experiência e, paradoxalmente, na maioria das vezes, esta aspiração é alcançada não através da abstinência ou da negação, mas através da saciedade e da exaustão: devora-se tudo, consome-se a cultura. $\mathrm{O}$ argumento de Benjamin evidencia uma pobreza nos fluxos sociais que não se corporificam, não se adensam o suficiente para que algo possa engendrar-se, e uma experiência possa se dar. O que resta são conclusões, encerramentos, assepsias, impermeabilidade e evitação total ao contágio ou às contaminações. Ou seja, toda experiência possível fica capturada e encerrada. Nada de aberturas, de problemas, de questões e percursos, as experiências estão determinadas, circunscrevem-se a um universo de finitude de combinações analógicas e empobrecidas. Não se trata de uma posição de ignorância, a pobreza em relação à experiência se dá pelo excesso, pelo bloqueio que a técnica e as truculências que ela permitira provocaram, obstruindo o fluxo, inviabilizando transmissões e passagens. 
Em Ensaio sobre a destruição da experiência, Giorgio Agamben acusa essa expropriação da experiência ao homem contemporâneo, ele a refere como aquilo que não mais se pode fazer.

[...] é esta incapacidade de traduzir-se em experiência que torna hoje insuportável - como em momento algum no passado - a existência cotidiana, e não uma pretensa má qualidade ou insignificância da vida contemporânea confrontada com a do passado (aliás, talvez jamais como hoje a existência cotidiana tenha sido tão rica de eventos significativos). (AGAMBEN, 2005, p. 21-2.)

Agamben pontua uma alteração fundamental da experiência, ela deixou de ser simples transmissão do cotidiano, do ordinário e passou a ser a exigência do extraordinário que, paradoxalmente, acaba não podendo nunca ser traduzido em experiência.

Porque a experiência tem o seu necessário correlato não no conhecimento, mas na autoridade, ou seja, na palavra e no conto, e hoje ninguém mais parece dispor de autoridade suficiente para garantir uma experiência, e se dela dispõe, nem ao menos o aflora a ideia de fundamentar em uma experiência a própria autoridade. Ao contrário, o que caracteriza o tempo presente é que toda autoridade tem seu fundamento no "inexperienciável", e ninguém admitiria aceitar como válida uma autoridade cujo único título de legitimação fosse uma experiência. (AGAMBEN, 2005, p. 23.)

Ainda sob este ponto de vista da experimentação pode-se dizer que ela deriva da expropriação da experiência implícita no projeto da ciência moderna, conforme Agamben aborda neste ensaio. Retomando uma frase do filósofo Francis Bacon, ele aponta como, tradicionalmente, a experiência espontânea seria correspondente ao acaso e aquela que é buscada propositadamente seria denominada experimento, donde advém a noção de experimentação que aqui se busca tratar. Experimentação enquanto operação para achar estas experiências, sintonizada a uma série de pensamentos e autores que dela dispõe para afirmar uma relação com o campo do vivido que pressuponha a alteridade. 
$\mathrm{O}$

alinhamento

das

noções

de

experiência/experimentação, aos nichos de engendramento e invenção aos poucos apresentados neste estudo, aproximam-se ainda dos traços que Foucault refere numa entrevista, corroborando para uma afirmação do qualquer, dessubjetivado, ponto de convergência e complexidade do pensamento por multiplicidade, importante para a clínica e para a vida.

A experiência, é tentar alcançar um certo ponto da vida que seja o mais próximo possível do invivível. O que se requer é o máximo de intensidade e, ao mesmo tempo, de impossibilidade. [...] A experiência tem por função retirar o sujeito de si mesmo, fazer com que ele não seja ele mesmo ou que ele seja levado a sua negação ou a sua dissolução. É uma empreitada de dessubjetivação. ${ }^{10}$ (FOUCAULT, 1984.)

Assim disparada, a escrita aqui supõe então, nas questões que se acrescentam, focos que direcionam para certas experimentações, que ao serem abordadas na forma de texto podem transmitir-se. Fragmentos sob a forma de narrativas, descrições e mapeamentos que estejam em afinidade com a necessidade de bem-escrever algo que pertence à vida, no que tange sua experiência-limite, suas dobras, suas fissuras.

10 Trad. livre do trecho: “[...] l'expérience, c'est essayer de parvenir à un certain point de la vie qui soit le plus près possible de l'invivable. Ce qui est requis est le maximum d'intensité et, en même temps, d'impossibilité. [...] l'expérience a pour fonction d'arracher le sujet à lui-même, de faire en sorte qu'il ne soit plus lui-même ou qu'il soit porté à son anéantissement ou à sa dissolution. C'est une entreprise de dé-subjectivation.’] 
Invenção. Da classificação taxonômica, modelo para a ciência moderna que delimita e determina projetos e obras. Dispositio, considerar o plano como sua própria ordenação. Não há ordens precedentes. A ordem como parte da invenção do plano. Digressão da categorização estereotipada, grade de estruturas fixas. $\mathrm{O}$ que não se encaixa: desvio, deformação. A cada texto exigem-se novas classes. E sempre há os fora das classes. 'Comunidade dos sem comunidade', escreveu Bataille. Elementos para uma categorização que não se sustenta diante de inevitáveis mutações e efemeridades. "Abandonamos as listas mas não a vontade de colocar problemas, de expor exigências" (RIERA, 2004, p.10). Cada conjunto de marcas pode ser visto como paisagem, o que comporta e deseja mudanças súbitas, imprevisíveis: anomalias e fissuras. Desclassificados para funcionar uma outra ordenação.

Fazer comunidade: escrever?

Toda boa escrita é nadar embaixo da água e prender a respiração.

FITZGERALD, F.S.

Uma película que já anunciava sua saída do lugar de obra, em pouco tempo não seria mais um filme, talvez continuaria a ser caracterizado deste modo em função dos materiais e equipamentos empregados, mas o modo já não suportaria esta designação... Poucas frases, muitos olhares $e$ cabelos nos rostos, e peles se encostando e se contaminando sem que hajam sentimentos. As emoções são dispensadas. Por vezes são mencionadas em algumas falas, mas não correspondem aos corpos... OSSOS, assim se chama o filme de Pedro Costa, realizador português. Sem que haja uma combinação, muito mais por amontoamento - resultado provável da falta de moradia -, alguns movimentos comuns vão se delineando, deslocamentos sem finalidade aparente, embora haja um bebê que alinhave fragilmente estas transposições... Não se trata de uma obra aberta, trata-se de uma ausência de obra, da constatação da impossibilidade de fazer obra. Uma espécie de adesão ao aberto, ao fora, como lugar de algum acontecimento não sabido, nem esperado, talvez confiado. Não 
é nem o fechado que encontra frestas, é o próprio aberto, aquilo que responde à multiplicidade de modo mais radical, na medida em que não se unifica, no máximo se amarra em feixes: de forças, de órgãos, de pensamentos, de matérias, de seres, criando ordenações temporárias.

O arranjo possível de um texto - sua ordenação, seu suposto sistema - constitui sua disposição, que pode conceber-se operacionalmente, durante sua feitura, ou vincular-se a ordens predeterminadas. $\mathrm{O}$ esfacelamento da obra, diferente de configurar uma destruição, suspende enquadramentos reificados o que favorece a invenção de uma estruturação própria, no entanto, ela nunca vai cumprir-se completamente, uma vez que em se tratando de uma proposta de ordenação, ela também indica a produção de uma obra, e portanto está, neste circuito, fadada a ser desmanchada, a não concluir-se como obra. Deste modo, as disposições deste texto colocam-se em comum para a constituição de um plano, ainda que se saiba que, com isto, elas nem farão parte de uma comunidade paradigmática preexistente ou em formação, nem fundarão um novo paradigma ou uma outra comunidade. Um texto que não pertence e não pertencerá, nem é e não será proprietário de nenhum elemento deste comum que o constitui e é constituído por ele. Os sentidos aqui não podem traçar-se como objetivos e metas, nem por efeitos e resultados; podem apenas constelar-se numa disposição. Nesse interregno entre obra e nada, nessa proposição que não se completa, estranhamente, uma existência é possível e, seja como for, é a esta ausência de obra que este texto se dispõe.

Um dos tópicos de Blanchot no livro La communauté inavouable, refere o "princípio de incompletude" e ecoa as indagações de Bataille:

Por que "comunidade"? A resposta é dada [por Bataille] muito claramente: "Na base de cada ser, existe um princípio de insuficiência..." (princípio de incompletude). É um princípio, notemos bem, aquilo que comanda e ordena a 
possibilidade de um ser. Daí resulta que esta falta, por princípio, não é acompanhada por uma necessidade de completude. O ser, insuficiente, não busca associar-se a um outro para formar uma substância de integridade. A consciência da insuficiência vem de seu próprio questionamento, o qual tem necessidade do outro ou de um outro para ser efetuado. Só, o ser se fecha, adormece e se tranquiliza. ${ }^{11}$ (BLANCHOT, 1983, p.15-6)

Ao redizer Blanchot, o que sucede a este texto é que o desejo de escrevê-lo encontra-se pautado sobre algo inconfessável. Inconfessável, primeiramente, pela aparente trivialidade e fácil depreciação em sua afecção mais imediata: o desejo de falar da experiência de comunidade. Esse constrangimento relaciona-se ao fato de que esta ideia seja, em geral, empregada abusivamente, sob a nomeação comunismo, tendo seus sentidos banalizados, cultivados na forma de exigências comunitárias, prescritas, em sua maioria, numa chave humanista que facilmente recai em orientações autoritárias, palavras de ordem comunitaristas e/ou socialitaristas, idílios e pesadelos da história mundial. Entretanto, o inconfessável de Blanchot refere-se a outro entendimento, que talvez coexista com este embaraço, a saber, o da ousadia de um pensamento que não se completa, um pensamento sem obra, pensamento que precisa revelar-se e entretanto não pode, porque seu traço se desvanece antes de se adensar. Persistir neste pensamento, desejar sua experiência inexperienciável é a linha de risco em que se inscreve este texto, atraída pela abertura que isto pode comportar, abertura essa sempre na iminência de desviar-se, de transtornar sua direção e de tornar-se a sublinha de destaque de alguma forma pronta.

11 Tradução livre do trecho: "Pourquoi $<<$ communauté $>>$ ? La réponse est donnée assez clairement: $<<\mathrm{A}$ la base de chaque être, il existe un principe $\mathrm{d}^{\prime}$ insuffisance... $>>$ (principe d'incomplétude). C'est un principe, notonsle bien, cela qui commande et ordonne la possibilité d'un être. D'où il résulte que ce manque par principe ne va par de pair avec une nécessité de complétude. L'être, insuffisant, ne cherche pas à s'associer à un autre pour former une substance d'intégrité. La conscience de l'insuffisance vient de sa propre mise en question, laquelle a besoin de l'autre ou d'un autre pour être effectuée. Seul, l'être se ferme, s'endort et se tranquilise." 
Em nota ao prefácio para a edição em espanhol de seu livro "A comunidade inoperante" Jean-Luc Nancy refere este desalinhamento.

Contudo, tampouco se pode deixar de sublinhar a dissimetria entre, por um lado, os fascismos que procedem de uma afirmação sobre a essência da comunidade, e por outro os comunismos, que pronunciam a comunidade como práxis e não como substância: isto marca uma diferença que nenhuma má fé pode suprimir. (NANCY, 2000, p. 8)

O viver junto, a coexistência num conjunto de acontecimentos e encontros, a constituição de experiências ainda que efêmeras, descontínuas e mutantes são indícios de uma comunidade por fazer-se, cuja razão não é outra senão a de pensar, como em Blanchot, sobre aquilo que

\begin{abstract}
interroga nosso mundo - o mundo que é nosso para não ser de ninguém - a partir do esquecimento, não das comunidades que nele subsistem (ou melhor, se multiplicam), mas da exigência "comunitária", que as obceca talvez, e à qual, nele, quase certamente, se deve renunciar. ${ }^{12}$ (BLANCHOT, 1983, p.51)
\end{abstract}

Linhas de abolição. Junto ao desejo pela vida coletiva estão seus microfascismos, suas direções compulsórias que imantam e enredam a todos. Compelidos às redes, os comportamentos se prescrevem como condição para não se estar nunca só, como se comunidade e solidão fossem termos opositivos. Cada vez menos a solidão é suportada, menos ainda desejada, ainda que ela seja inevitável. Para a leitura e crítica dessas coerções travestidas de acolhimento e inclusão a que se está imerso no âmbito da política e de suas implicações cotidianas, inclusive na clínica, que confundem, na relação com o comum, o "poder fazer" (potência ética) e o "ter que fazer" (dever moral), Deleuze e Guattari efetuam uma distinção:

12 Tradução livre do trecho: “[...] interroge notre monde - le monde que est nôtre pour n'être a personne - à partir de l'oubli, non pas des communautés qui y subsistent (elles se multiplient plutôt), mais de 1 'exigence $<<$ communautaire $>>$ qui les hante peut-être, mais s'y renonce presque sûrement." 
Não é todo mundo que se torna como todo mundo, que faz de todo mundo um devir. É preciso para isto muita ascese, sobriedade: eliminar o percebido demais, o excessivo-paraperceber. [...] Pois, todo mundo é o conjunto molar, mas devir todo mundo é outro caso, que põe em jogo o cosmo com seus componentes moleculares. Devir todo mundo é fazer mundo, fazer um mundo. (DELEUZE; GUATTARI, 1997a, p. 73)

$\mathrm{Na}$ experiência clínica, o problema da inclusão/inserção social, cultural, ou qualquer que seja, inscreve-se nessas direções compulsórias. Direitos que compelem, ditadura do para todos, cujos representantes e defensores encaram desafios e lutas importantes para o acesso a direitos considerados básicos e fundamentais, ao mesmo tempo, que se armam para aplicá-los a todos, sempre que possível, recaindo em fórmulas coercitivas, que reiteram as identidades como condição de pertencimento a alguma "comunidade" do mundo. Um ser qualquer não tem direitos a serem defendidos ou reivindicados, ele não se representa e não pode ser representado.

Um ser que fosse radicalmente privado de toda a identidade representável seria para o Estado absolutamente irrelevante. É o que, na nossa cultura, o dogma hipócrita do caráter sagrado da vida e as vazias declarações sobre os direitos do homem têm o objetivo de esconder. (AGAMBEN, 1993, p. 67-8)

(In)Humano. Não há nenhuma destinação biológica, histórica ou espiritual que determinaria as prescrições para a vida humana, atributos para atingir uma suposta essência do homem, que definiriam necessidades a priori. $\mathrm{O}$ que o homem pode ser encontra-se sempre numa zona de indeterminação que se justifica apenas em sua própria potência ou possibilidade de ser algo que não se sabe o que é.

o ser humano precisa de não estar sempre no quotidiano, precisa de sair do quotidiano e entrar noutros níveis, noutra sensação do mundo, precisa de fazer coisas não produtivas, sair da lógica da produção, ter objetivos diferentes desses, precisa de voltar a saber que não há só um caminho entorpecedor e mecânico, que a vida é mais subtil do que 
isso, mais rica em redes e nós de sentidos e sensações, de linhas que se cruzam, se baralham e iluminam. (MANTERO, 1998, p. 03-4)

A vida humana não pode manter-se vinculada a destinos e vocações; a condição de débito em relação a sua existência é inconveniente para o pensamento do homem, se este protocolo humano essencial tivesse que se cumprir, "não existiria nenhuma experiência ética possível - haveria apenas deveres a realizar." (AGAMBEN, 1993, p. 38). O que se está dispondo aqui atravessa entendimentos sutis, pois à primeira vista, prescindir de uma qualificação que represente o homem, sua essência particular e individual, parece ser uma proposta de indiferenciação. Entretanto, nesse esfacelamento da identidade homem, na explosão de sua unidade indivisível estaria, segundo a noção de comum que estamos perseguindo neste texto, a própria emergência da humanidade, das singularidades impessoais, da vida. "Comunidade como compartilhamento de uma separação dada pela singularidade.” (PELBART, 2003, p.33). Estranha formulação, mas é disso que se trata: a comunidade humana, no limite, dispensa o homem.

Não há nada de paradoxal na constatação de que o homem, no qual toda a comunidade se perdeu, é também aquele que funda a possibilidade da comunidade verdadeira, neste caso da comunidade simplesmente. [...] Porque é exatamente na medida em que ele não é um indivíduo, que o Bloom está em condições de estabelecer relações com seus semelhantes. Enquanto o in-divíduo traz em si, de modo atávico, a ilusão funesta de uma imanência fechada do homem nele mesmo, o Bloom deixa entrever o princípio da incompletude que se encontra no fundamento de toda existência humana. Ao mesmo tempo que para o Bloom, este Eu que é um Nós impessoal (On), este Nós impessoal (On) que é um Eu, a consciência de si é imediatamente consciência de si como outro, e do outro como si, ele sente a si mesmo como o nada. Isto é, o puro ser-para-a-morte, diante do qual estão colocadas suas determinações, suas qualidades, sua aparência, isto é, seu ser, que ele descobre como idêntico ao seu ser-em-comum, ao seu ser-exposto, ao ser-fora-de-si. O Bloom não faz, portanto, a experiência de uma finitude particular ou de uma separação determinada, mas $d a$ finitude e $d a$ separação ontológicas comuns a todos os homens. Do mesmo modo que o Bloom só está só em aparência, porque 
ele não é o único a estar só, todos os homens tem esta solidão em comum. Ele vive como um estrangeiro em seu próprio país, à margem de tudo e sem Publicidade, mas todos os Bloom habitam juntos a pátria do Exílio. Todos os Bloom pertencem indistintamente a um mesmo mundo que é o esquecimento do mundo. ${ }^{13}$ (TIQQUN 1, p. 36)

Outra saúde. De que são feitas as comunidades deste texto? Pistas: marcas que na clínica podem inscrever-se sobre a superfície de percursos molares, de sofrimento instituído e institucionalizado; encontros com a gravidade da vida: situações de urgência e emergência, linhas que fazem oscilar entre o mais vital e o mais fascista. Trajetórias de contato singulares entre os campos das artes e da clínica a partir da experiência profissional como terapeuta ocupacional, sobretudo os projetos que tomam as artes como instrumentos de proposição e crítica para ações com populações em processos que pode-se chamar de desfiliação, anormalidade, desvantagem ou vulnerabilidade social, de exclusão ou marginalidade - conforme o referencial teórico e/ou ético-político que se adote seus processos são designados em função de seu sofrimento mental (loucos), de sua deficiência (física, sensorial - cegos ou surdos, e mental) e/ou de sua situação de risco social (drogaditos, crianças na rua, moradores de favelas, moradores de rua, idosos etc).

13 Tradução livre do trecho: "Il n'y a rien de paradoxal dans le constat que l'homme en qui toute communauté s'est perdue est aussi celui qui fonde la possibilité de la communauté véritable, et à ce titre de la communauté tout court. [...] Car c'est exactement dans la mesure où il n'est pas un individu que le Bloom est à même de nouer des relations avec ses semblables. Tandis que l'in-dividu porte en lui de façon atavique l'illusion funeste d'une immanence close de l'homme à lui-même, le Bloom laisse entrevoir le principe d'incomplétude qui se trouve au fondement de toute existence humaine. En même temps que pour le Bloom, ce Je qui est un On, ce On qui est un Je, la conscience de soi est immédiatement conscience de soi comme autre et conscience de l'autre comme soi, il s'éprouve lui-même comme le rien. c'est-à-dire le pur être-pour-la-mort, en face duquel sont posées ses déterminations, ses qualités, son apparence, c'est-à-dire son être, qu'il découvre comme identique à son être-en-commun, à son être-exposé, à son être-hors-desoi. Le Bloom ne fait donc pas l'expérience d'une finitude particulière ou d'une séparation déterminée, mais de la finitude et de la séparation ontologiques communes à tous les hommes. Aussi bien, le Bloom n'est seul qu'en apparence, car il n'est pas seul à être seul, tous les hommes ont cette solitude en commun. Il vit comme un étranger dans son propre pays, en marge de tout et sans Publicité, mais tous les Bloom habitent ensemble la patrie de l'Exil. Tous les Bloom appartiennent indistinctement à un même monde qui est l'oubli du monde." 
Como expandir uma sensibilidade e construir um estofo para acolher estes encontros constituindo com eles modos heterogêneos de trabalhar com conjuntos heterogêneos? Um procedimento cirúrgico seria então efetuado. Enfrentamento um: o modo generalizado chamado inclusão. Primeiro corte: suprimir a separação de grupos que, em geral são chamados de público especial, dos demais grupos populacionais. Esta opção está inserida num conjunto maior de questionamento ético e político que relaciona-se aos processos de inclusão social e toda problemática que este termo e suas práticas implicam. Não se trata de suprimir as diferenças e desvantagens que certos estados de impedimento físico, dificuldade cognitiva e/ou fragilidade mental produzem, mas de inscrever seus entendimentos num espectro mais ampliado que proponha dispositivos de vida em conexão, onde as singularidades se entrevêem, mas não se destacam.

Para efeito de rápida demarcação das circunstâncias em que estes processos se iniciam, referindo-se aos movimentos relacionados à questão da inclusão social, tem-se, no Brasil, nas décadas de 70 e 80 :

1) Movimentos de Luta Antimanicomial e de Reforma Psiquiátrica (referidos aos movimentos italianos liderados por Franco Basaglia a partir de uma legislação que institui o fim dos manicômios) que efetivaram desmontagens de instituições psiquiátricas e construção de redes de serviços substitutivos (CAPs, NAPs, hospitais-dia, centros de convivência, residências terapêuticas, cooperativas de trabalho, escritórios de advocacia, projetos artísticos e culturais, etc), além de lutas pela consolidação de leis que viabilizassem e fortalecessem esses processos.

2) Movimentos de Defesa dos Direitos da Pessoa com Deficiência, disparados sobretudo pelos organismos internacionais (ONU e OMS) e efetuado por organismos e associações de pessoas com deficiência, familiares e técnicos. 
Com reivindicações relacionadas a elementos de acessibilidade (arquitetônica e relacional) e de cidadania (participação social moradia, inclusão escolar, trabalho e geração de renda, transporte etc).

Equívoco do corte: diante deste cenário de movimentos e lutas indiscutivelmente valiosas, que, com variações persistem até hoje, faz-se necessária uma redobrada atenção, ao risco que uma ideia de inclusão social pode arrastar consigo, a saber, o risco de neutralização da alteridade, da estranheza, risco paradoxal mas absolutamente presente.

Trata-se de saber, primeiramente, se faremos com os loucos aquilo que já se fez com homossexuais, índios, crianças ou outras minorias - ou seja, definir-lhes uma identidade, atribuir-lhes um lugar, direitos, reconhecimento, até mesmo privilégios - mas ao mesmo tempo torná-los inofensivos, esvaziando seu potencial de desterritorialização entenda-se esse poder secreto e admirável de embaralhar os códigos, subverter as regras do jogo e transpor ou deslocar os limites, sempre de outro modo, seja através de um devir-bicha, de um devir-negro, de um devir-nômade ou de um devir-louco, e ora assumindo um rosto estranho, ora ameaçador, sacrílego, herege, criminoso ou delirante. (PELBART, 1990, p.104.)

Ponto duro, essa inclusão salvacionista toma, muitas vezes de forma obstinada e fundamental, o funcionamento social hegemônico e central como sendo aquele ao qual deve-se fazer acessar todos os que gravitam a sua margem ou os que não estão a ele aderidos ou filiados, e por que não dizer, submetidos. Desprezada a oportunidade de se tomar a própria gravitação, ou não-adesão, ou desfiliação também como motivação para uma crítica, no sentido daquilo que coloca em crise a própria ordem social. Crise nos encontros, a desterritorialização da figura do técnico de saúde, educador e/ou assistente social provoca vertigem das posições de ajuda e de saber, e portanto de poder.

No traço "marginalidade", dos seminários Como viver Junto, Barthes fala positivamente de uma "experiência de marginalidade [...] direito de certos indivíduos (ou de pequenos grupos 
de indivíduos) de viver à parte, no seio da comunidade" (BARTHES, 2003, p.175). Na seqüência ele escreve sobre como a sociedade suporta esta experiência somente na medida de sua vigilância e controle, através de seus próprios mandados de obediência e estabilidade que configuram-se sintomaticamente como valores de integração. "A margem é entretanto tolerada, como abscesso de fixação [...] - mas com a condição de ser controlada pela sociedade, isto é, codificada por ela." (BARTHES, 2003, p.180)

A resistência possível a este mandado, qual será? Resistir não inventando a roda mas fazendo-a rodar em outras direções, menos reconhecíveis. Isto implicaria uma abertura a universos de sensibilidade outros, a adoção de um posição de vínculo com o vital, o que pode muito apropriadamente ser pensado em conexão com as artes na contemporaneidade, supondo aquelas inscritas na experimentação.

aquela [arte] que reata certos fios do experimental não mais como tática para vôos futuros, mas como reflexão sobre ideias e procedimentos próprios do processo de elaboração das relações entre um presente e um passado, na imanência dos trabalhos sempre singularizados. Não se acredita, então, que os trabalhos visem à atualização das potencialidades modernas, como que redimindo uma origem traída - as promessas do novo como suporte de uma outra unidade, a uma outra totalização da experiência. Ao contrário, esses trabalhos apontam para as dificuldades da percepção contemporânea, uma vez que ela não pode unificar o campo e nem se referir a uma estética determinada. Cada trabalho remete ao campo aberto da arte, solicita e inclui outros trabalhos, postula a multiplicidade de sujeitos. Esta arte se mantém pela aguda consciência de sua materialidade e pela tentativa de se afirmar como fato da cultura: desidealizada, vive dos efeitos advindos da evanescência do simbólico. (FAVARETTO, 2006, p.251-7)

Essa resistência implica também numa oportunidade de reinvenção das relações entre o estranho e as ações coletivas das quais ele venha a participar - nas quais incluem-se as clínicas, educativas, e as artísticas. Permitir que cada um se 'enganche' ao seu próprio modo na proposição, a tarefa do acompanhante (monitor, terapeuta, professor) seria a de propiciar encontros 
sem os impor, numa delicadeza que nesse passeio com estranhos deixe sua voz emergir, suas experiências culturais com os elementos de diferença do mundo constituídos a partir de vivências de extrema singularidade (com uma visão turva ou escurecida, com silêncios e sonoridades distorcidas, com imobilidades físicas, deslocamentos comprometidos, aparências fortemente distintas do modelo hegemônico, com agitações ininterruptas, com relações temporais discrepantes, com conexões de sentido interrompidas, lentidões, defeitos, baba, caminhares errantes, delírios, fracionamentos, etc).

Este movimento de descentramento é reconhecível na mesma ideia de "partição" - que remete ao mesmo tempo a "compartilhar" e a "partida" -: a comunidade não é nunca um lugar de chegada mas sempre de partida. É assim a própria partida até o que não nos pertence e que não poderá nunca pertencer-nos. Por isso a communitas está muito longe de produzir efeitos de agrupamento, de associação, de comunhão. Não acalenta e não protege. Ao contrário expõe o sujeito ao risco mais extremo: o de perder, com sua própria individualidade os limites que garantem sua intangilibilidade por parte do outro. De resvalar repentinamente no nada da coisa. (ESPOSITO, 2008, p. 39-40)

Páthos das distâncias. Uma proposta de negociar distâncias. Pensar que o contato com estes sujeitos pode proporcionar uma espécie de vitalização, na medida em que pode convocar o pensamento a questionar os automatizados modos de aproximação e contato, que provavelmente só têm rastros pulverizados de disponibilidade à alteridade. "Seria, sem dúvida, o problema mais importante do Viver-Junto: encontrar e regular a distância crítica, para além e para aquém da qual se produz uma crise.(A crítica visa colocar em crise) [...]. o que é desejado é uma distância que não quebre o afeto.” (BARTHES, 2003, p.258.) Em geral, no encontro, acionam-se estratégias de neutralização do que no outro possa haver de estranho, estratégias que têm a ver sobretudo com o arsenal de explicações e ilustrações, representações que entopem cada um, e que são aplicadas sobre o outro, numa imposição comunicativa. Curiosamente, essas 
estratégias costumam não dar certo com estas populações, elas resistem, possuem alguma estranha força de esquivar-se dos aplainamentos, destas tentativas de achatar suas geologias singulares, suas existências não-lineares e rugosas... E esta resistência, que em alguns momentos se configura até mesmo como recusa, não deve ser lamentada em sua incapacidade de corresponder às expectativas previamente traçadas, devem sim ser tomadas afirmativamente, como uma oportunidade de fazer surgir algo inesperado, de irromper uma comunidade subtraída as imagens e gestos prontos.

[...] que a comunidade esteja ligada não a um mais, mas a um menos, de subjetividade quer dizer que seus membros já não são idênticos a si mesmos, senão constitutivamente expostos a uma tendência que os leva a forçar seus próprios confins individuais para abismar-se em seu "fora". Desde este ponto de vista - que rompe toda a continuidade do "comum" com o "próprio", ligando-o mais ao impróprio retorna ao primeiro plano a figura do outro. Se o sujeito da comunidade não é mais o "mesmo", será necessariamente um "outro". Não outro sujeito, mas uma cadeia de alterações que não se fixa nunca em uma nova identidade. (ESPOSITO, 2008, p.38)

Que nenhum dos elementos torne-se elemento de destaque, mas que todos possam compor paisagens, preservando as distâncias como um modo de não soterrar nenhum deles. Propõe-se com isto uma sensibilidade de cenário, uma experiência estética que valha em suas pequenas sensações e percepções. Delicadeza.

Delicadeza seria: distância e cuidado, ausência de peso na relação, e, entretanto, calor intenso dessa relação. O princípio seria: lidar com o outro, os outros, não manipulálos, renunciar ativamente às imagens(de uns, de outros), evitar tudo o que pode alimentar o imaginário da relação. (BARTHES, 2003, p. 260.)

Sob a égide desta delicadeza é que uma outra saúde - no sentido de um esboço descontínuo, incompleto e efêmero -, se faz. Gestos de apego à vida, não para fazer sua manutenção, mas como desejo de existir transitoriamente em comunidades: estarem-comum, e perceber-se como elemento que define a existência de algo mais que um conjunto de eus individuais. 
Uma outra saúde que possa articular-se à doença e emergir na escrita como uma fenda.

Não se escreve com as próprias neuroses. A neurose, a psicose não são passagens de vida, mas estados em que se cai quando o processo é interrompido, impedido, colmatado. A doença não é processo, mas parada do processo [...]. Por isso, o escritor enquanto tal, não é doente, mas antes médico, médico de si próprio e do mundo. O mundo é o conjunto dos sintomas cuja doença se confunde com o homem. A literatura aparece, então como um empreendimento de saúde: não que o escritor tenha forçosamente uma saúde de ferro, mas ele goza de uma frágil saúde irresistível, que provém do fato de ter visto e ouvido coisas demasiado grandes para ele, fortes demais, irrespiráveis, cuja passagem o esgota, dando-lhe contudo devires que uma gorda saúde dominante tornaria impossíveis. [...] Qual saúde bastaria para libertar a vida em toda parte onde esteja aprisionada pelo homem e no homem, pelos organismos e gêneros e no interior deles? [...] A saúde como literatura, como escrita, consiste em inventar um povo que falta. Compete à função fabuladora inventar um povo. (DELEUZE, 1997, p. 13-4).

Comunidade de escritura. Nas possíveis ordenações deste texto, a pretensão de narrar experiências clínicas e mencionar com elas certas configurações do comum, é uma possibilidade que só pontualmente deixa entrever alguma comunidade. Ela só existe no momentos em que não é possível distinguir seu simples registro de seu esquecimento. Em meio às experimentações com o comum, o envolvimento com o curso das experiências, bem como com os acrescentamentos e contribuições que a sua transmissão impossível poderia legar, arrisca esta escrita que pode tomar as direções de fuga pretendidas, mas também, sem o saber, pode decair em formulações dogmáticas comunitárias. De todo modo, com as precauções possíveis, uma vez tornado narrativa, o invivível do vivido quer aqui alçar-se ao estatuto de uma outra comunidade, que seria uma maneira de desviar-se de uma concepção transcendental, que sacralizaria a experiência e usurparia dela seu poder sobre a vida cotidiana.

[...] De nada nos serve a tentativa patética ou fanática de apontar no enigmático o seu lado enigmático; só devassamos 
o mistério na medida em que o encontramos no cotidiano, graças a uma ótica dialética que vê o cotidiano como impenetrável e o impenetrável como cotidiano. (BENJAMIN, 1994, p.33).

Esta comunidade, feita de escritos vivos que dizem o indizível da vida, seria um modo delicado de resistência às totalizações comunitaristas. Uma comunidade da escritura, tal qual a proposta de La communauté désouvrée, de Jean-Luc Nancy (2001), uma escritura da comunidade por vir, que coloca em comum o político, traço singular de nosso ser-em comum.

Político seria o traçado da singularidade, de sua comunicação, de seu êxtase. "Político" quer dizer uma comunidade que se orienta ao desobramento de sua comunicação, ou enquanto destinada ao dito desobramento: uma comunidade que faz conscientemente a experiência de sua partição. Alcançar tal significação do "político" não depende, ou não simplesmente em todo caso, do que se chama uma "vontade política". Isso implica já estar comprometido na comunidade, quer dizer, fazer da maneira que seja, a experiência da comunidade enquanto comunicação: isso implica escrever. Não se pode deixar de escrever, não se pode deixar de expor o traçado singular de nosso ser-em-comum. (NANCY, 2001, p. 77)

Escrever: estratégia para alcançar o acontecimento por vir. Escrever pela premente necessidade de reportar um acontecimento que já foi, sem por isto ter sido. Narrar o que não pode ser narrado.

Essa é uma das estranhezas, ou melhor, das pretensões da narrativa. Ela só "narra" a si mesma, e essa relação, ao mesmo tempo que se faz, produz o que conta, só é possível como relação se realiza o que nessa relação acontece, pois ela detém então o ponto ou o plano em que a realidade que a narrativa "descreve" pode continuamente unir-se à sua realidade como narrativa, garanti-la e aí encontrar sua fiança. (BLANCHOT, 2005, p. 9)

A disposição deste texto apura-se na direção do desobramento tal qual proposta por Blanchot (apud NANCY, 2005, p.61-2), que toma a comunidade aquém e além da obra, como aquilo que se retira da obra. Assim, este escrito retira-se da chave da produção, do consumo, e avança na interrupção, na fragmentação, e nas suspensões. As comunidades advindas 
dele e nele esmaecidas serão formadas pelas lacunas das singularidades que dele emergem, e por sua vírgula. Comunidade para a arte de não fazer obra. 


\section{[EXPERIMENTOS]}

Lâminas. Justaposição e diafaneidade. Imagina um livro impresso em transparências, reunidas as histórias de alguém, sua leitura é a visualização de um escrito ilegível, amontoados de letras justapostas e contrastadas pela passagem da luz. Estabelece escritos numa relação experimental, de diferenciação sutil. Deseja trabalhar numa exterioridade, sem operar para espessuras internas. A vida, tubo de ensaio prestes a explodir misturas. Prioriza superfícies, movimentos sobre e sob o plano. Aforismos não se estabelecem por seqüências contínuas. A lâmina é "qualquer coisa muito fina e chata, lasca, fatia, faixa, tira"; ou "parte cortante de arma branca ou de instrumento destinado a cortar, furar, talhar, raspar etc.”. Delgada e por vezes capaz de tornar-se imperceptível, matéria consistente e invisível. De um paciente: "- Só admito ser eu mesmo, se eu tiver uma ou mais destas coisas, coisas que eu vou dizer, pejorativas: ou ser paciente psiquiátrico, ou ser negro, ou ser mulher ou ser velho." Nada que se possa subestimar: preenchimentos que se ligam para delimitar o buraco. Completude do halo, circunscrição do vazio. "Observem que, em toda parte e em tudo, o que é sutil sustenta o que é compacto, e o que é leve mantém suspenso tudo o que é pesado." (JOUBERT apud BLANCHOT, p. 83.)

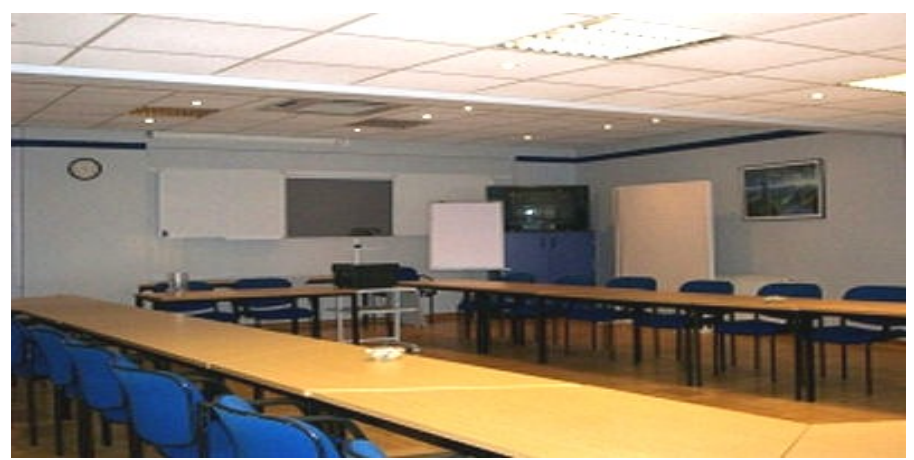

... alguns dias sentavam naquela sala de conferências, num pequeno hotel do estrangeiro, e divagavam sobre o que não sabiam estar acontecendo naquilo que viviam... 


\section{narrativas: experiências em abismo}

Narração é a exposição das coisas
como ocorreram ou como
poderiam ter ocorrido.

[CÍCERO]

Eu tenho experiência e não estou brincando quando digo que essa experiência é uma espécie de enjôo em terra firme",

Franz Kafka

apud Walter Benjamin

Daquilo que está ou esteve vivo numa experiência, nenhuma transposição pode fazer-se, nenhuma língua pode alcançar. Numa sequência arbitrária, conveniente somente para o fluxo deste texto, sucedem duas noções de experiência, que dialogam entre si e intensificam a ideia de uma experiência em abismo, nos termos que se propõe neste escrito.

A experiência interior de Bataille,

Quis que a experiência conduzisse para onde ela quisesse, não quis levá-la para algum fim predeterminado. E digo logo que ela não leva a refúgio algum (mas a um lugar de extravio, de contra-senso). Quis que o não-saber fosse o seu princípio. [...] Mas essa experiência, nascida do não-saber, aí permanece, decididamente. Ela não é inefável, não a traímos se falamos dela, mas nas questões do saber, ela furta até mesmo ao espírito as respostas que este ainda tinha. A experiência não revela nada e não pode fundar a crença, nem partir dela. ${ }^{14}(2008$, p. $15-16)$

A experiência limite de Blanchot,

A experiência limite é aquela que espera esse homem último, capaz uma última vez de não se deter nessa suficiência que atinge; ela é o desejo do homem sem desejo, a insatisfação daquele que está satisfeito "em tudo", a pura falta, ali onde no entanto há consumação do ser. A experiência limite é a experiência daquilo que existe fora de

14 Trad. livre do trecho: "J'ai voulu que l'expérience conduise où elle menait, non la mener à quelque fin donnée d'avance. Et je dis aussitôt qu'lle ne mène à aucun havre (mais en un lieu d'égarement, de non-sens). J'ai voulu que le nonsavoir en soit le principe [...] Mais cette expérience née du non-savoir y demeure décidément. Elle n'est pas ineffable, on ne la trahit pas si l'on en parle, mais aux questions du savoir, elle dérobe même à l'esprit les réponses qu'il avait encore. L'expérience ne révèle rien et ne peut fonder la croyance ni en partir." 
tudo, quando o tudo exclui todo exterior, daquilo que falta alcançar, quando tudo está alcançado, e que falta conhecer, quando tudo é conhecido: o próprio inacessível, o próprio desconhecido. [...] Não se trata de extorquir uma última recusa a partir do descontentamento vago que nos acompanha até o fim; não se trata tampouco desse poder de dizer não, pelo qual tudo se faz no mundo, cada valor, cada autoridade sendo derrubada por outra, cada vez mais extensa. O que está implícito em nossa proposição é absolutamente outra coisa, exatamente isso: que ao homem, tal como é, tal como será, pertence uma falta essencial de onde lhe vem esse direito de se colocar a si próprio sempre em questão. E reencontramos nossa observação precedente: o homem é esse ser que não esgota sua negatividade na ação, de modo que, quando tudo está acabado, quando o "fazer" (por meio do qual o homem também se faz) se consuma, quando portanto o homem nada mais tem a fazer, é necessário que exista - como o exprime Georges Bataille com a mais simples profundidade - em estado de "negatividade sem emprego", e a experiência interior é a maneira pela qual se afirma essa negação radical que não tem mais nada a negar. (BLANCHOT, 2007b, p.187-8)

A justaposição destas noções dão espessura ao pensamento da experiência tal qual se quer que ela seja aqui entendida: experiência insuficiente, que erige apenas questões e que não constela saberes, experiência que, longe de ser irracional ou absurda, em seu caráter disruptivo, afirma o nada, contrastado ao essencial e absoluto do racionalismo científico.

No desenho deste quadro de noções, em Benjamin a experiência é tomada numa diferenciação importante realizada a partir dos vocábulos alemão Erlebnis - que ele relaciona à experiência vivida ou vivência que é privada e particular e, Erfahrung - referente à experiência coletiva fundadora da narrativa tradicional antiga (GAGNEBIN, 1994, p.15). Esta distinção é ao mesmo tempo o manejo de uma viragem que se dá na modernidade, uma vez que nela a experiência coletiva teria se perdido, se esfacelado, o que não é tomado por ele como signo de melancolia, mas como de mudança que permite, paradoxalmente, que a experiência possa ser narrada em sua própria impossibilidade - nisto suas acepções justapõem-se as de Bataille e Blanchot. 
Experiências em abismo são a própria negação da experiência, na medida em que elas só experimentam da experiência sua possibilidade que não se cumpre, e que se esquece, com o que elas se inventam. Uma vez invivível, menos ainda narrável. E nisso está a persistência vacante deste texto.

Alguns elementos se alistam como se fosse possível organizar com eles uma porção compacta de mundo e exibi-la numa imagem luminosa que servisse a um esclarecimento universal. Conforme a tessitura vai se fazendo, os desencaixes sobressaem-se e nem o emprego de muita força poderia obrigálos a se cravarem - mas, principalmente, não é isto que se quer. Enfim, tudo se disjunta e sobrenada numa mistura em que os elementos não se fundem, apenas entrevêem-se num habitat de convivências casuais, que não tomam a forma de unidades nem de ideais. Uma experiência que parecia acabada, considerando ter se passado num tempo ido, quando acionada sua lembrança, deixa perceptível sua atualidade. Ela recomeça de um ponto que já não corresponde ao que poderiam ser seus fatos, e embaralha a memória que só pode então saber do seu esquecimento, perdendo o controle que julgava ter sobre esta experiência e ficando à merce de sua mais recente duração, que jamais formulará respostas e, se o for, só será capaz de achar suas perguntas.

- Agora, a srta. Hudson fechou o livro - disse Rhoda. Agora, o terror está começando. Agora, pegando o pedaço de giz, ela desenha números, seis, sete, oito, depois uma cruz e uma linha no quadro-negro. Qual a resposta? Os outros olham; olham compreendendo. Louis escreve; Susan escreve; Neville escreve; Jinny escreve; até Bernard começou a escrever agora. Mas não sei escrever. Vejo apenas números. Os outros estão entregando suas respostas, uma a uma. Agora, é minha vez. Não tenho resposta. Os outros recebem licença para sair. Batem a porta. A srta. Hudson sai. Fico sozinha para encontrar a resposta. Agora os números não significam coisa alguma. $\mathrm{O}$ sentido se foi. $\mathrm{O}$ relógio tiquetaqueia. Os ponteiros são comboios marchando por um deserto. As listras negras na cara do relógio são oásis verdes. O ponteiro comprido marchou para encontrar água. $\mathrm{O}$ outro cambaleia penosamente entre pedras ardentes no deserto. A porta da cozinha bate. Cães selvagens latem e 
contém em si o mundo. Começo a desenhar um algarismo e o mundo está contido na sua curvatura, e eu própria estou fora dela; agora, fecho essa curva - assim - e a cerro e torno-a inteiriça. O mundo está ali inteiro e eu fora dele chorando: "Ah, não me deixem ficar para sempre fora da curva do tempo!"'(WOOLF, 2004, p. 15)

Pensar o que não pode ser pensado, pensar com o esquecimento. Apresentar uma certa clínica enredando invenções é uma aposta duplamente cara - importante e custosa -, na medida em que engendra uma escrita que é sua própria interrogação, eventualmente, até mesmo sua negação. A complexidade de empreender estas narrativas encontra-se na pretensão de dizer o que não pode ser dito, de contar a nãoexperiência de uma experiência, sua dimensão impalpável, e que, todavia, não se pode deixar de testemunhar. E o testemunho é seu esquecimento, única lembrança que da experiência se pode reter.

Assim, a lei do esquecimento se exercia também no interior da obra. Pois um acontecimento vivido é finito, ou pelo menos encerrado na esfera do vivido, ao passo que o acontecimento lembrado é sem limites, porque é apenas uma chave para tudo o que veio antes e depois. Num outro sentido, é a reminiscência que prescreve, com rigor, o modo de textura. Ou seja, a unidade do texto está apenas no da própria recordação, e não na pessoa do autor, e muito menos na ação. (BENJAMIN, 1994, p. 37)

$\mathrm{O}$ acesso à própria experiência ocorre na mesma medida em que se percebe sua inacessibilidade. Tal constatação dispara ansiedades que, neste caso, somam-se aos pontos de contágio dessa clínica com uma arte, mencionada aqui através dos projetos da cia. teatral Ueinzz e do Ateliê Experimental (РАCTO - USP), cujos grupos são formados por aqueles que têm trajetórias marcadas pela loucura, pela deficiência e/ou pela vulnerabilidade social. Num cotidiano profissional, que tem a terapia ocupacional como circunstância inicial, acentua-se a dificuldade em preservar um poder de interrogação, uma vez que impõem-se, frequentemente, situações-limite das quais não se 
pode esquivar e cujas respostas exigem posições de resistência na indeterminação, para não recorrer a voluntarismos nem a suas coerções correspondentes.

Fora de domínio, a experiência é uma exigência que nunca se consuma, pois não pode ser confirmada por nenhuma rememoração, ela ultrapassa toda memória e "somente o esquecimento acha-se a sua medida, o imenso esquecimento que leva à palavra" (BLANCHOT, 2007b, p.195). É a partir desse esquecimento da experiência que se propõem aqui narrativas clínicas, que tentam contar acontecimentos da clínica mas que também, ao fazê-lo, emprega seu próprio modo, ou seja, o faz clinicamente. Com isto, coleciona-se um quantum de forças em imagens e paisagens que dão consistência à própria afirmação da clínica, e que dispõem sua sensibilidade e suas sensações para a escuta dos mundos, os mais próximos e os distantes. As narrativas, em sua invenção, não são tomadas por referência ou ilustração, elas têm a função de engendrar uma posição de discurso para esses acontecimentos supostamente significativos e pungentes, e esta posição será o exercício do seu próprio pensamento, operando por deslocamento da clínica para a cultura (em sua publicidade, enquanto lugar da experiência coletiva), e da cultura para a clínica como um modo de restabelecer traços do comum à vida.

$\mathrm{Na}$ dimensão vivencial das experiências, tomadas como ponto de partida para narrativas, a incidência da experimentação e da aprendizagem em processos clínicos mais convencionais e outros que guardem relações diretas com as artes (através do ensino do ofício de algumas delas, da exploração do território em que obras e ateliês se alojam e da proposição de novos formatos de experimentação estética, com populações muitas vezes exiladas em serviços de tratamento à saúde) são critérios que favorecem uma mínima materialidade, visualizável em conjuntos de cenas que, a seguir, ver-se-ão dissolvidos, na medida em que as narrativas se produzem. Com essa dimensão 
tangível, as narrativas pretendem guardar, no plano das sensações, apenas uma relação de verossimilhança e de ressonância, aludindo aos elementos que na experiência questionam e deflagram a própria impossibilidade de serem contados. A partir de revivescências - memórias e esquecimentos que envolvem sensações -, as narrativas emergem.

A sensação é o contrário do fácil e do lugar-comum, do clichê, mas também do "sensacional", do espontâneo etc. [...] a sensação é o que se transmite diretamente, evitando o desvio ou o tédio de uma história a ser contada. (DELEUZE, 2007, p. $42-3$ )

O caráter direto da sensação, proposto nessas significações e relacionado àquilo que evita um encadeamento previsível e ilustrativo - na tal "história a ser contada" -, desvela, provavelmente uma outra maneira de contar, que configure um plano de sensações. Tal qual a montagem de um elemento de trânsito no interior do dispositivo de escrita, por justaposição de sensações, aos poucos, prepara-se uma canoa, frágil, mas que conduz e se enreda na consistência do texto, "o plano não é princípio de organização, mas meio de transporte" (DELEUZE; GUATTARI, 1997a, p. 57-8).

Paradoxal, esta relação entre narração e sensação faz com que o relato vivencial deixe de ser espelho da narrativa, e restrinja-se à emergência dos trajetos da experiência que se entrevêem eventualmente na narrativa. Salvaguarda-se, desse modo, à narrativa, a potência de fazer-se em invenções.

A narrativa não é o relato do acontecimento, mas o próprio acontecimento, o acesso a esse acontecimento, o lugar aonde ele é chamado para acontecer, acontecimento ainda por vir e cujo poder de atração permite que a narrativa possa esperar, também ela, realizar-se.

Essa é uma relação muito delicada, sem dúvida uma espécie de extravagância, mas é a lei secreta da narrativa. A narrativa é movimento em direção a um ponto, não apenas desconhecido, ignorado, estranho, mas tal que é só dele que a narrativa extrai sua atração, de modo que ela não pode nem mesmo "começar" antes de o haver alcançado; e, no entanto é somente a narrativa e seu movimento imprevisível que 
fornecem o espaço onde o ponto se torna real, poderoso e atraente. (BLANCHOT, 2005, p. 08)

$\mathrm{Na}$ medida em que se narra, a própria narrativa se interroga. Esta é sua posição de discurso, e a perspectiva na qual aí se enuncia fabula o acontecimento. "Não há literatura sem fabulação" (DELEUZE, 1997, p. 13). A estratégia de fabulação é reticente no âmbito da clínica. Fabular a clínica implica, na escrita, fabricar experimentos com uma narração heteróclita, que é invenção e ao mesmo tempo alusão de um vivencial desejado e não realizado na experiência. Supondo uma "faculdade especial de alucinação voluntária" Bergson (1998, p. 161) nomeou por "função fabuladora" aquilo que pode alinhar-se à ficção e que, entretanto, não pode circunscrever-se a ser pensado como apenas uma variedade da imaginação. A fabulação guarda relação com as sensações e percepções da memória, entretanto ela funciona como uma espécie de resistência à dimensão factual (da ciência, sobretudo) que tende a acachapar toda experiência. Neste sentido, ela teria a capacidade de suscitar

"imaginários" que resistirão à representação do real e que conseguirão, por meio da própria inteligência, contrapor-se ao trabalho intelectual. Assim se explicaria a função fabuladora. Se, ademais, ela desempenha um papel social, deve servir também ao indivíduo, que a sociedade tem o mais das vezes interesse em controlar. Pode-se presumir que, sob sua forma elementar e original, ela traz ao próprio indivíduo um acréscimo de força. (BERGSON, 1998, p. 99.)

$\mathrm{Na}$ tentativa de apresentar experiências clínicas desertando os modos hegemônicos e estereotipados, este procedimento pretende atingir um lugar diferente daquele que a alçaria ao estatuto de ciência, e que, provavelmente, a obstinaria em busca de uma suposta verdade, postulando modelos e transformando-a numa enunciação coorporativa ou pedagógica. Alternativa a este destino à ciência, a escritura assume suas implicações discursivas e engenha-se pautada em uma posição declarada, sem nada intencionar para além do texto. A escritura 
seria um lugar discursivo em que uma certa fabulação da clínica funcionaria como um mecanismo de sua narrativa, engendrando uma outra experiência, sempre descontínua, com áreas de interrogação e silêncio a serem preservadas.

Escrever é um ato intransitivo. Assim sendo, a escritura "inaugura uma ambiguidade", pois mesmo quando ela afirma, não faz mais do que interrogar. Sua "verdade" não é uma adequação a um referente exterior, mas o fruto de sua própria organização, resposta provisória da linguagem a uma pergunta sempre aberta. (PERRONE-MOISÉS, 2005, p. 33)

Narrativas engendram-se então, em experimentos vinculados àquilo que as interroga. Simultaneamente elas pretendem contar o invivido da experiência e duvidar da possibilidade de sua própria subsistência. Elas empregam elementos que compõem as enunciações e determinam os modos discursivos, revelando suas operações, coerências, subversões, e clausuras subjugadoras, e seus modos de construírem-se a esgotam, as desfaz, não atingindo o caráter de um feito, de uma obra.

Este esgotamento da obra instiga na escrita um procedimento por diferenciações, que impede que a narrativa seja tomada como uma descrição positiva, estritamente factual ou empírica. Ao migrar do procedimento descritivo, factual, a escrita adentra uma zona de indeterminação que pode tender a algumas direções, a saber, o ornamental e o literário, para destacar duas. Quando uma escritura não se destina à verificação de verdade, ou ainda, de estabelecimento de uma verdade, é grande a chance de que seja tomada como ornamento, numa sentença que estabelece séries em hierarquia: uma enaltecida que relaciona o factível com o necessário e importante; e uma outra desqualificada - em que se localiza o ficcional (ornamental) como desnecessário e irrelevante. Assim, se a narrativa aqui é uma invenção, uma fabulação, ela estaria fadada a tornar-se dispensável e nula. Com efeito, tramadas, as narrativas deste texto em nada pretendem tornar-se 
indispensáveis ou valiosas, e no entanto, não se trata também de tomá-las como ornamentos, e enclausurá-las em categorizações pejorativas condenando-as ao terreno dos enfeites ou do decorativo, numa escala cujo parâmetro seriam as verdades factuais. Isso interessa a uma abordagem dos discursos e escrituras possíveis de se produzir no terreno da clínica, uma vez que, por tratar-se de matéria passível de aplicações e entendimentos pragmáticos, a força do discurso científico se impõe na clínica sobre outros modos de enunciação, que privilegiam zonas de sensibilidade e indiscernibilidade. Com isto, condenam-se as experiências clínicas ao âmbito da técnica e aquilo que não se enquadra neste discurso técnico-científico termina por ser menosprezado ou excluído do campo acadêmico e, mais grave, da própria formação de terapeutas. Ensinamentos históricos, metodológicos, políticos, procedimentais etc, é isto que predomina ou até mesmo domina os currículos de formação de terapeutas. E tão prontos estão todos, que quando algo da ordem da escritura ou da literatura, sobrevém em alguma disciplina, pouco valor recebe no conjunto - surge minoritário e assim fica, esmagado entre receitas, técnicas, fórmulas, projetos, testes, raciocínios, avaliações, protocolos e análises. Esse conjunto de aportes técnicos não precisa contrapor-se à possibilidade de outras pragmáticas para a clínica que podem comportar invenções e "preocupação com a delicadeza das verdades" (BLANCHOT, 2007b, p. 184). Se as narrativas em forma de pergunta podem encetar-se nestas regiões da clínica, com elas pode-se ensaiar saídas das lógicas de inclusão-exclusão, e de determinação hierárquica de relevâncias, de falsos e verdadeiros.

Sem eximir-se das complicações que isto dispara, este texto abre-se nessa direção em que uma multiplicidade de escrituras, leituras e ensinamentos podem coexistir e acrescentar-se por justaposição ou por contraste. Conhecer os textos antigos, nesse sentido, com seus gêneros de discurso inscritos na Retórica - que guardam fortes relações com a 
experiência comum, e com a alteridade -, ensina a interrogar e a suspeitar de certos funcionamentos tomados como se sempre estivessem ali ou como se tivessem se formado a partir de uma pungência natural. Aprende-se a pensar, com elementos que interrogam as categorias às quais, automaticamente, se costuma submeter o conhecimento.

Considerar os gêneros de discurso e os elementos deles indissociáveis é uma perspectiva importante para a clínica neste contato com as artes, e na produção de suas narrativas, na medida em que neles apresenta-se um raciocínio que difere do raciocínio empírico (que quer encontrar um ponto único de onde tudo deve irradiar e para onde tudo deve convergir) tal qual se maneja nos experimentos de narrativas deste texto. Se as narrativas só podem ser tomadas como um experimento efêmero e em perspectiva, a comprovação factual de seus elementos e de seus arranjos não é essencial - além dos apresentados sempre haverão outros que não puderam ser elencados, além de outras combinações que não foram feitas.

[a narrativa] trata daquilo que não pode ser verificado, daquilo que não pode ser objeto de uma constatação ou de um relato. A narrativa é o lugar da imantação, que atrai a figura real para os pontos em que ela deve se colocar, respondendo ao fascínio de sua sombra. (BLANCHOT, 2005, p. 271).

A força de justaposição dos elementos da narrativa está na decisão por uma direção, na escolha pautada num princípio eletivo o mais impessoal, e não num modelo único e irrefutável, o que caracteriza sua posição. Não se tratam de operações canônicas com os gêneros de discurso, nem de buscar neles uma verdade paradigmática, ou um modelo generalizável, mas de usar sua racionalidade e transpô-la aqui a fim de fazer coexistir as categorias do pensar, em múltiplas direções, as mais contraditórias e lacerantes. Um exercício de leitura da clínica que considere o discurso em seus gêneros, os lugares de onde se enuncia, exige uma mudança nos regimes de sensibilidade, 
convocando a deambulações, impedindo a fixação em uma perspectiva exclusiva.

A necessidade de afirmar relações de superfície, no geral, e na clínica de um modo especial, concorre para um conjunto de estratégias de deserção do processo de interiorização (e profundidade), produzido a partir do séc. XVI e muito fortalecido em fins do XVIII e início do XIX, que marca toda nossa tradição romântica. Esta tradição, plena de interioridade, de grandes investimentos no $\mathrm{eu}$, na crença de que o que temos em comum é o que está dentro de cada um em particular, supõe uma individualidade que legitima e institucionaliza, atribuindo poder à clínica, em suas diversas disciplinas e profissões, tal qual a conhecemos hoje. Com a valorização do que está nas superfícies, retoma-se um certo pathos da antiguidade que opera nos textos latinos, em que nada vem de dentro, tudo se dá num espaço de intervalo, se dá fora, na fricção das superfícies, sem lamentar ou almejar a profundidade, nem supor que ela exista por trás ou abaixo das superfícies. O que vem, os acontecimentos, são agenciamentos de muitos elementos e interferências que não são da ordem do $e u^{15}$.

A fala da voz não pode mesmo ser expressão de um "quem" subjetivado ou individualizado como unidade imaginária atestada por um nome próprio num registro civil e numa história de vida. É ficção arqueológica feita de enunciados fósseis de vozes que não são apenas vozes do sujeito que fala, evidenciando que eu é legião e que sempre faltará. (HANSEN, 2009, p. 24)

Seguir esta direção e insistir na importância de um procedimento narrativo que opere pelas superfícies implica

15 Embora este tema não seja abordado diretamente neste texto, é necessário ressaltar que esta questão da deserção do $e u$, que constitui dispositivos de práticas e enunciações heterogêneas para a clínica, complica-se à medida em que, simultânea ou alternativamente sua potência de impessoalidade é enclausurada em relações burocráticas (pautada em protocolos e evidências), apresentando também sua vertente "tecnocrática" de gestão das diferenças (RABINOW, 2002, p. 145) e postulando verdades absolutas. $\mathrm{O}$ que exige que a complexidade deste desenho de forças não seja tratada sob a restrita operação de dissolução do $e u$, como se esta fosse uma saída, em si mesma, revolucionária. 
afirmar o acontecimento em sua verossimilhança e impessoalidade, validada além e aquém de qualquer explicação ou relação causal que se lhe queira atribuir. A defecção completa do impulso a esses esclarecimentos fundamentais é árdua, uma vez que são hegemônicas nos modos de pensar da cultura ocidental. Não se pode subestimar a condição servil, marcada pelos ideais românticos e humanistas, a que todos se submetem. No mínimo, o que se pode adotar são posições que evitem aderir a conclusões forjadas, e desconfiem delas enquanto totalidades ou absolutos.

Cada manhã recebemos notícias de todo o mundo. E, no entanto, somos pobre em histórias surpreendentes. A razão é que os fatos já nos chegam acompanhados de explicações. Em outras palavras: quase nada do que acontece está a serviço da narrativa, e quase tudo está a serviço da informação. Metade da arte narrativa está em evitar explicações. (BENJAMIN, 1994, p. 203).

Deslizar narrativas por sobre as superfícies dos acontecimentos, ao contrário do que se pode pensar automaticamente, dá concretude ao pensamento. Concreto, o pensamento se libera dos funcionamentos abstracionais - forte herança que nos assalta e nos faz sair por aí sobrepondo sentidos, distribuindo generalizações, associando exclusivamente a partir de teorias e ignorando a matéria. A abstração nesta perspectiva é aquilo que opera por isolamentos, por movimentos que forçam os signos a tornarem-se emblemas, símbolos e modelos que passam a predeterminar a experiência, impedem o estranhamento e o devir, condenam tudo a ser sempre o mesmo. Por outro lado, o concreto seria aquilo que funciona por agregação, por agenciamentos da matéria, numa relação empírica, sensitiva e, quiçá, analítica, operando por decomposição.

Nesta abordagem concreta - que talvez pudesse também caracterizar-se como instantânea e/ou imediata -, as categorias empregadas para a operação dos elementos por vezes são 
reduzidas a relações de causa e efeito, de origem e finalidade, em práticas voluntariosas, que restringem a experiência ao universo do eu, recrudescendo as possibilidades de sua enunciação e arrogando-se indicar respostas, afirmar o tal conhecimento adquirido.

Essa pretensão do Eu é o signo de sua impostura. O eu nunca foi o sujeito da experiência; o "eu" jamais o consegue, nem o indivíduo que sou, essa partícula de pó, nem o eu de todos que supostamente representa a consciência absoluta de si: mas só a ignorância que encarnaria o Eu-que-morre ao aceder a esse espaço em que, morrendo, ele não morre nunca como "Eu", em primeira pessoa. É preciso portanto indicar pela última vez o traço mais estranho - o mais pesado dessa situação. Falamos dela como de uma experiência e, no entanto, jamais poderemos dizer tê-la experimentado. Experiência que não é um acontecimento vivido, muito menos um estado de nós mesmos: no máximo a experiêncialimite onde talvez os limites caem e que só nos alcança no limite, quando, tendo todo o futuro se tornado presente, pela resolução do Sim decisivo, afirma-se a ascendência sobre a qual não há mais domínio" (BLANCHOT, 2007b, p. 193).

Entradas súbitas, conjugação de inflexões que não permitem um encerramento, somente hipóteses, perguntas. Os experimentos apresentados aqui em narrativas clínicas exigem uma cautela para sua leitura que não suporta, assim como em sua escrita, qualquer fechamento apressado de sentido, eles resistem em não propor finalidades ou utilidades, nem generalizações, considerando que quanto mais se conjectura ou se tenta impetrar aprofundamentos, mais se distancia dos acontecimentos, sejam os do texto, sejam os da clínica. 
EXPERIMENTO I

Cozinhando gentes - heterogeneidade e antropofagia

- Quem traz o quê?

$1 / 2 \mathrm{~kg}$ de tomates

6 ou 8 beringelas

- Olha que berinjela rende muito!

- Acho que não?

- Então, quantas?

- Ah, traz seis.

2 cebolas grandes

- Pode trazer picada?

1 vidro de azeitonas

1 lata de molho de tomate

mais uma

mais duas

1 litro de refrigerante

200gr de muzzarela

mais

300 gr de muzzarela

- Deixa que eu trago o vinho!

- De jeito nenhum!

- Eu vou trazer!

- Não, quem vai trazer isto sou eu. (Já pensou o 'chabu'... eu trazendo já é problema...) 
- Eu trago o vinho, Erika.

- Não insista, acabou esta conversa.

2 pés de alface

- E ele que chegou agora?

- Traz uma margarina ou um refrigerante. A massa eu vou trazer.

Diálogo da Preparação. Conversa que acontece, mais ou menos uma vez por mês: todos sentados em volta da mesa grande. Há quem sente e levante todo o tempo. Há quem fique alheio. Há quem peça para ir embora. Há quem fale sem parar. Há quem repita tudo. Há quem sugira baixinho. E quem fale sobre outro assunto.

Assim, é só de vez em quando. Mas sempre acontece.

Segunda-feira, 16h00. Ficamos juntos até mais tarde. Quando não é horário de verão, escurece. Não dá pra ver a novela e o jantar atrasa. No hall de entrada, pelos corredores e na cozinha uma circulação pouco convencional. Alguns falam ininterruptamente, falam alto, falam com entidades invisíveis, outros andam de um lado ao outro incessantes, em silêncio, alguns olhos arregalados, algumas cabeças baixas, corpos em prontidão, uns inquietos, outros afundados nos assentos da sala de espera.

Em dias comuns, estudantes coordenam a preparação do café que será compartilhado em algum momento daquele encontro: escolhe-se o sabor do suco (às vezes em pó, às vezes líquido, sempre artificial e bem colorido), quando surgem algumas frutas elas são organizadas em potes, junto aos bolos ou biscoitos que são espalhados em bandejas - um tanto é fornecido pelo serviço, outro tanto é contribuição de cada um, conforme suas possibilidades e querências. 
Aos poucos, este arremedo de prédio, vai se esvaziando de seus outros habitantes - professores e estudantes de fisioterapia, fonoaudiologia e terapia ocupacional. E restam apenas estes poucos estranhos...

...um homem velho, com uma paralisia do lado esquerdo do corpo, resultado de um Acidente Vascular Encefálico. Um homem triste. Geme. Traz imagens de filmes, conta da sua semana em frases enigmáticas por causa de sua afasia. Ele quer falar da cunhada que mora em outro bairro, e diz a vizinha. Não lembra. Esqueceu. Pensa que seu problema é contagioso, quando fica sabendo de um homem de sua rua que também teve um A.V.E. Debocha do companheiro de grupo cujo time perdeu para o Corinthians...

...dois irmãos com deficiência mental e alguns comprometimentos psíquicos. Anomalias genéticas.

Um tagarela impertinente, interrompe as falas, fala muito alto, quer oferecer assuntos para manter as pessoas por perto. Repete a mesma história inventada. Fabula a ida ao campo de futebol, o lanche de pernil, os palavrões. Fabula a transa com uma namorada. Não consegue ficar quieto, quer amigos.

O outro é desconjuntado, cabisbaixo, se move de um modo rebolante e desengonçado e vai ecoando todos os finais de frase das conversas alheias, baixinho. Quer se perder um pouco. Algumas vezes toma o ônibus errado e atrasa para voltar para casa. Canta e dança a Rita Lee, o Abba e a Xuxa.

...presença marcante e assustadora, num corpo em bloco, musculoso. Rema na raia da universidade há muitos anos. Joga futebol num time misturado. Anda pela cidade. Olha os discos em sebos: Iron Maden, Mettálica. Um rapaz jovem, com comprometimentos psíquicos graves - ensimesmamentos e alucinações constantes. Síndrome do X frágil. Olha as moças e 
sorri envergonhado. Chega atrasado. Chega muito adiantado. Espera muito. Diz que já terminou o que foi proposto, mal os outros começaram. Tem pressa de vagar...

...o corpo prestes a cair de uma senhora velha com um cisto no lóbulo frontal - doença de PIC. Devagarinho ela chega. Uma mulher silenciosa e anestesiada, a vida guardada, mas persistente: quer fazer todos os movimentos. E escorrega da escada no final de semana e chega muito machucada. Começou a fazer as unhas e a andar mais arrumada. Ensinou uma receita ao grupo, de modo severo, na cozinha. Pede ajuda e chora pequenininho. Quando o neto aparece na porta da sala, dá um salto e o agarra com força. Cumprimenta e se despede de um a um...

...gordinho muito amigo e disponível, inventivo na designação das coisas. Olha o vídeo com a imagem do boneco que tinha moldado: "São gêmeos!". Desenha seres moles. Transpira muito. Um rapaz jovem com uma deficiência mental acentuada, associada a uma gagueira. Passa seus dias assistindo à TV. Frequenta um grupo de jovens na igreja. Tímido, ele está muito atento aos outros, quer que todos estejam presentes. Lamenta as faltas. Dá ideias simples, às vezes no desvio do assunto, conforme seu entendimento tão concreto que chega a ser poético.

...cheia de fragilidades afetivas e psíquicas, uma moça adulta, com sequelas de paralisia cerebral, transborda interesses e desejos tolhidos, numa coleção de médicos e tratamentos. Passa muito mal com qualquer aproximação, e ao mesmo tempo roga por elas de modo exigente e exclusivo. De repente vai embora porque o copo era de plástico e ela ia passar vergonha por não conseguir segurá-lo por causa das deformidades de suas mãos. Se enfeita e nos presenteia. Escreve cartas amorosas e 
dramáticas. Cozinha muito bem e nos traz complementos para o lanche. Fica atenta aos movimentos de cada participante e acena quando acha que há problemas com eles. Diz ter medo deles e os cuida. Sorri e diz que sou má porque em seus sonhos, eu insisto em mostrar-lhe um espelho...

...com gestos e comportamentos obsessivos, um rapaz que toca ininterruptamente por onde passa, uma fala apressada e muitas vezes ininteligível, precisa sair para beber água e tem dor de barriga. Falta. Depois vem. Coleciona papéis. O bolso da bermuda fica lotado, com uma protuberância de folhetos e jornais dobrados. Canta e batuca alegremente conforme consegue relaxar-se. Pinta o papel até antes da borda. Uma inquieta e hesitante presença que não ocupa.

...olhar assustado e de longo alcance sem alcançar nada. Esse menino adulto, de traços autísticos significativos: frases repetidas, gestos bruscos, alternâncias súbitas. Chega atrasado. Tira o sapato. Quer deitar. Põe o sapato. Quer ficar só com a meia. Tira a meia. Se vira de bruços e começa a esfregar-se. É interrompido. Vem para o grupo. Quer guardar o colchão. Não sabe se vai calçar o tênis agora. De repente ele grita: "Vagabundo! Vagabuuuuuuuundo!" Come tudo até acabar. Fala docemente. Conta de suas brigas. Diz que ficou com raiva mas que vai ficar "bonzinho" e "contente".

...procedimento correto, tudo direito: vai, faz o que tem que fazer, no horário certo. Um rapaz franzino que se apresenta assim. Uma substância apaziguada para suportar a pressão da vida: mortes de homens familiares, solidão e embotamento. Projeta uma grande unificação do hemisfério norte com o hemisfério sul e uma moeda forte africana que vai circular por todo o mundo. Suspeita das nossas pequenas transgressões 
(risos, brincadeiras, danças), não quer sair de perto. Desenha bandeiras de países imaginários...

...grunhidos altos, fortes e próximos a nossa boca. O mais jovem de todos, se destaca pela pele muito negra. Não articula nenhuma palavra, e está agudamente presente. Distúrbio global do desenvolvimento. Seu corpo oscila para frente e para trás e por vezes salta e bate palmas de um modo muito expressivo. Um pássaro de olhos arregalados. Quer devolver o material que colocamos em sua mão e anda atrás e nos toma pelos braços contundentemente. Guerreia pelos potes com biscoitos, soltando sons guturais em pulsos intermitentes. Guarda todos os bonecos em meio à atividade. Ajuda a por o queijo sobre a massa. Come as uvas como uma maçã.

Monstros, anômalos, loucos, anormais. "O ser que vem é o ser qualquer" (AGAMBEN, 1990. p. 9). A estranheza de tentar compor algo num conjunto tão heterogêneo sem homogeneizálo, sem destacar linhas, sem sucumbir a seus traços de mortificação, e somente fazê-lo digno do que vir a nos acontecer. "O ser qualquer entretém uma relação original com o desejo" (AGAMBEN, 1990. p. 9). Retrospectivamente, é possível pensar que é nesta moralidade de quereres dessubjetivados que nos pautamos, para sermos dignos do que nos acontece. Querer o acontecimento, considerando que "o acontecimento não é o que acontece (acidente), ele é no que acontece o puro expresso que nos dá sinal e nos espera." (DELEUZE, 2000, p.152), Estas singularidades todas reunidas num grupo de tratamento, dentro de uma instituição de ensino e pesquisa, num projeto de extensão universitária seriam elementos fadados a uma configuração triste, de adestramentos, ressentimentos, lamentos do que se passou, reparação, reabilitação. Entretanto as linhas que concorriam ali, tendiam a uma fuga vitalizadora, onde estariam então estes pontos de resistência que marcavam este encontro? 
Alguns familiares ficam na sala de espera, vigiando o passar das horas e o desaparecimento da luz solar. Muitos protestos e tentativas de mudança do horário de funcionamento ocorreram, cedemos pouco, a gestão institucional (horário das salas, dos profissionais e das disciplinas de estágio) se sobrepôs e permanecemos na passagem do claro para o escuro de cada dia.

Com o tempo, aprendemos a otimizar isto que parecia uma desvantagem, sair de um atendimento à noite, no escuro... $\mathrm{E}$ aos poucos este evento foi fazendo parte do cotidiano destas pessoas, algo que acontece num pulso temporal contínuo, muitos deles não têm outras referências de tempo, mas têm a deste horário, deste ponto...

Ateliê Experimental ${ }^{16}$ foi o nome que o projeto recebeu e neste experimental coube $\mathrm{o}$ fazer junto muitas $\operatorname{coisas}^{17}$. Entretanto, nos primeiros encontros, nossa alma se estreitara. A responsabilidade por este trabalho era desesperadora para a equipe de coordenação $^{18}$ : a lentidão, o desentendimento, a

16 Este projeto desenvolve-se junto ao Programa Permanente de Composições Artísticas e Terapia Ocupacional (PACTO-USP) - serviço de extensão do Laboratório de Estudos e Pesquisa Arte e Corpo em Terapia Ocupacional da FMUSP, coordenado pelas docentes Profa. Dra. Eliane Dias de Castro e Profa. Dra. Elizabeth Maria Freire de Araújo Lima, que funciona como espaço de extensão, pesquisa e ensino, sendo campo de estágio para alunos do $2^{\circ}, 3^{\circ}$ e $4^{\circ}$ ano do curso de graduação em terapia ocupacional da FMUSP. Alguns dos integrantes do grupo do Ateliê Experimental são atendidos também individualmente, pela Rede de Sustentação do PACTO, que realiza orientações de familiares e acompanhamentos terapêuticos para constituição de uma outra circulação cotidiana, efetuando encaminhamentos para outros espaços de atendimento clínico, bem como de atividades culturais da cidade de São Paulo e arredores.

17 Desde sua implantação em 2006, o projeto do Ateliê Experimental desenvolveu muitas pesquisas com atividades, tais como: - oficinas pontuais de sensibilização artística com pintura, desenho e modelagem; oficinas processuais com aprendizado técnico: escultura em pedra sabão, fotografia, vídeo; - oficinas de trabalho corporal: ginástica postural, improvisação e dança); e - eventos de convivência: cafés coletivos, passeios, lanches, jantares, festas.

18 A equipe de coordenação do projeto era composta inicialmente por mim terapeuta ocupacional, e pela artista e educadora Christiana Moraes. Desde o ano de 2008, a equipe passou a ser composta também pelas terapeutas ocupacionais Priscyla Mamy Okuyama e Renata Monteiro Buelau. Semestralmente estagiários e bolsistas do curso de terapia ocupacional da USP fazem parte desta equipe. 
dispersão, a sujeira, o silêncio, a prostração... As marcas mais mórbidas da deficiência mental e da loucura nos capturavam, e ficávamos totalmente desanimadas. Com uma persistência obstinada, depois de muitas semanas perdidos, com encontros esvaziados, os fios foram sendo achados e feixes de força se compuseram; as afinidades com as atividades, com os modos de dizer e de não dizer, com os movimentos do corpo, os deslocamentos singulares, as devorações, os gritos - todos os elementos de singularidade ganharam lugar e, ainda que quase sempre inesperados, puderam ser desejados.

Desde o início, traçaram-se linhas para a constituição de um dispositivo que, com a consistência ética de estabelecer relações em justaposição, eliminando o subjugamento e a dominação, conjugasse em outras combinatórias, aquilo que era comum nos projetos do mesmo programa (PACTO), a saber, as artes, o corpo e a convivência. Quando pensamos em dispositivo, pensamos no sentido de um misto de muitas linhas heterogêneas, cada uma de natureza diferente, que se mantêm singulares e diferentes sem dissolução e homogeneização que, como na proposição de Deleuze, "seguem direções, traçam processos que estão sempre em desequilíbrio, e que ora se aproximam, ora se afastam umas das outras" (1996, p.83).

O paradoxo neste projeto se dá, entre outras coisas, no fato de ser um projeto que propõe tratar, e que inventa seu tratamento na medida de sua evolução. Isto quer dizer, de uma práxis que não pré-existe à sua experiência, que aqueles que dela participam são os que a fazem existir. Não há como negligenciar que a medida da participação de cada um é distinta, no entanto, não é possível mensurar suas quantidades e intensidades, a não ser em cada acontecimento, retomando a proposição deleuziana de pensar "aquilo que acontece no que acontece". Terapeutas, artistas e estagiários estão engajados nos códigos vigentes e hegemônicos e portanto têm maior poder de circulação pelos 
elementos mais evidentes da experiência social. No entanto, esta facilidade de trânsito social pode banalizar a vida, e determinar uma distância de seus limites, de sua margem, sua "fissura", aquilo que dá potência e arruína a vida. Toda esta tecnologia para o viver, ao mesmo tempo favorece o alcance dos recursos mais pragmáticos para o funcionamento dos projetos, e simultaneamente impermeabiliza suas freqüências sutis e suas sensações mais agudas, fabricando profissionais blindados e engessados a certas experiências e proposições. Não estamos querendo com isto suprimir as assimetrias entre os postos de coordenação e os de participação, mas também não queremos fixar hierarquicamente estas ocupações, permitindo sempre que possível que elas se horizontalizem em sua diferença.

Quando um coordenador é obrigado a improvisar no decorrer de uma atividade, em geral, ele se fragiliza, pois vê-se interrogado em sua paralisia, apegada a uma programação que falhou e que não mais o sustenta naquela posição destacada, a composição desfunciona, impondo um arranjo outro dos elementos, não cabendo mais as sobreposições, obrigando combinações em justaposição. Esta fragilização deve ser bemvinda na medida em que ela desafia o terapeuta a achar outros modos, a mudar de posição e fluir no acontecimento. Desatar-se desta montagem hierárquica, que fixa o terapeuta na função de quem só pode acertar para ter comprovado seu saber maior e, por conseguinte, sua importância, é um gesto de fortalecimento. Uma vez aberto ao chamamento deste desafio, sua experiência intensifica-se e ganha evolução - efetua travessias, curso, fluência, não fica parada. Numa posição móvel, o terapeuta pode pensar, pode duvidar, pode acompanhar o outro sem sucumbir, nem subjugar.

Cada qual arriscava alguma coisa, foi o mais longe neste risco e tira daí um direito imprescritível. Que resta ao pensador abstrato quando dá conselhos de sabedoria e de distinção? Então, falar sempre do fermento de Bousquet, do alcoolismo de Fitzgerald e de Lowry, da loucura de Nietzsche e de Artaud, ficando à margem? Transformar-se 
no profissional destas conversações? Desejar apenas que aqueles que foram atingidos não se afundem demais? Fazer subscrições e números especiais? Ou então irmos nós mesmos provar um pouco, sermos um pouco alcoólatras, um pouco loucos, um pouco suicidas, um pouco guerrilheiros, apenas o bastante para aumentar a fissura, mas não para aprofundá-la irremediavelmente? Para onde quer que nos voltemos, tudo parece triste. Em verdade, como ficar na superfície sem permanecer à margem? Como salvar-se, salvando a superfície e toda a organização de superfície, inclusive a linguagem e a vida? Como atingir esta política, esta guerrilha completa? (DELEUZE, 2000, p.160-1)

A navegação neste território é estreita e seus alargamentos são efêmeros e importantes. Narrá-los parece ser uma tentativa de fortalecer suas extensões, intensificando-as ao inventá-las na língua. Este exercício torna-se parte do próprio dispositivo do Projeto. "Em suma, o dito e o não-dito, são elementos do dispositivo", é como Foucault o qualifica. "O dispositivo é a rede que se pode estabelecer entre estes elementos" (FOUCAULT, 1979, p. 244). Esta rede funciona, opera e maquina com estes elementos, ela os expõe e os ordena.

O dispositivo está sempre inscrito em um jogo de poder, estando sempre, no entanto, ligado a uma ou a configurações de saber que dele nascem, mas que igualmente o condicionam. É isto o dispositivo: estratégias de relações de força, sustentando tipos de saber, e sendo sustentadas por eles" (FOUCAULT, 1979, p. 246).

Neste jogo de poder, pensar as enunciações e os funcionamentos do coletivo deste projeto do Ateliê Experimental, os discursos e práticas que os sustentam, aponta para a difícil construção e invenção de arranjos, contanto que seus elementos misturem-se sem fundir-se e que possam preservar-se em relações de alteridade. $\mathrm{Na}$ medida em que estes "personagens" retratados acima passam a ser vistos de modo a minimizar os efeitos que a chave agente-paciente exerce nos espaços da clínica, sobrevém as singularidades, enquanto elementos desta mistura. Se estamos arrumando a mesa, alguém coloca a toalha, e outro deita a cabeça sobre ela até que lhe peçam para puxar a ponta, enquanto outro alguém circunda a 
mesa em pequenos saltos e um outro distribui os garfos e as facas usando uma só mão e sem se levantar da cadeira: é de uma espécie de paisagem que estamos falando. Dispositivo como paisagem.

A necessidade de acolher do ponto de vista cultural e social aqueles cujas marcas predominantes advém de vivências de sofrimento mental, deficiências e/ou outras situações de vulnerabilidade social, coloca a clínica numa encruzilhada: inventar um dispositivo que efetue este acolhimento responde simultaneamente a uma urgência social, que não é mais emergente, mas crônica, que afrouxa a tensão que eles poderiam exercer sobre os espaços de sociabilidade e cultura mais usuais que, em geral, não os comportam sem destacá-los, realçá-los.

Este destaque é decisivo na posição de projetos de mesma natureza que a do Ateliê Experimental, uma vez que ao pensar nestes realçamentos se quer questionar o que assistimos, sobretudo nas políticas públicas que são cada vez mais engendradas para estas populações: a constituição, sob o conceito tão aclamado da "inclusão", de ações que só serviriam para um impulso primeiro de alavancar o que está socialmente em grande desvantagem e que, no entanto, se mostram produzindo estratégias de tolerância e constrangimento social, que deixam estas populações paradoxalmente excluídas do lado de dentro dos espaços sociais, retirando delas, inclusive, a força de desestabilização que são a marca preponderante de resistência das posições marginais, instaurando um estado asséptico, aquilo que se chama o "politicamente correto". Seja uma criança com deficiência numa sala de aula convencional, um louco numa exposição de arte contemporânea, um menino de rua numa apresentação teatral, estas imagens apelam imediatamente ao encantamento misericordioso. Elas oferecem os valores da cultura e da sociabilidade hegemônicos para aqueles que há pouco nela não se enquadravam, por meio de adaptações e suportes espetaculares. Salvo algumas poucas iniciativas que 
constituem uma valoração transversal ao próprio território marginal, colocando seu fluxo resiliente para fazer funcionar uma crítica às diversas regiões segregadoras do sistema capitalístico, o que predomina é um cenário de relações identitárias que pouco interfere na experiência vital daqueles que estiveram invisíveis ou renegados e que passam a ficar evidentes e capitalizáveis para a boa fama de muitos artistas e empreendedores culturais e sociais, além de lançar fora a oportunidade de uma intervenção social no processo de fabricação de fragilidades e insuficiências que a sociedade de controle $^{19}$ exerce sobre todos, ressaltando a diversidade pela força das identificações e homogeneizações sucessivas.

No bojo desta complexidade, a constituição do dispositivo que forma o Ateliê Experimental - resultado também da elaboração que o PACTO pôde fazer a partir da experiência com grupos anteriores -, apresenta um outro ponto de sustentação do projeto: o trabalho em co-coordenação composto por profissionais de proveniências heterogêneas: uma terapeuta ocupacional e uma artista. Este assinalamento profissional só faz sentido se tomado como elemento de multiplicidade do dispositivo, quer dizer, num espaço destinado ao tratamento da saúde, a presença de uma artista, em seu aspecto identitário profissional, desloca de algum modo o imaginário social, para tanto, é importante que a artista não se torne terapeuta, que ela permaneça neste vórtice, nesta zona de indecidibilidade. No cotidiano do trabalho, não é a caracterização profissional o que determina a possibilidade de atravessamentos e misturas, ambas são referência no projeto, e sua heterogeneidade se define em dimensões mais sutis, menos visíveis, da ordem das delicadezas, que poderiam exercer-se por profissionais de mesma formação e ofício. Os papéis não são estabelecidos à priori, e, nesta contiguidade, o que marca as distâncias nas relações de poder é

19 A esse respeito ver DELEUZE, Gilles. Pós-scriptum para a sociedades de controle. In: DELEUZE, Gilles. Conversações. 1972-1990. Trad. Peter Pál Pelbart. Rio de Janeiro: Ed. 34, 1992, pp.219-26. 
menos o saber profissional, e mais os modos $\mathrm{e}$ as disponibilidades para esta relação, que incluem também os graus de contratualidade institucional. No cotidiano dos encontros essa coordenação mesclada funciona numa espécie de performance que se faz na medida da intimidade construída pelo grupo. Além da equipe de coordenação, até o ano de 2009, o grupo esteve composto pelos 11 adultos descritos acima neste texto, que foram encaminhados em diferentes momentos ao projeto, em função de suas histórias em serviços de saúde mental e/ou em instituições para pessoas com deficiências (física e mental). Cada um deles estabelece com a coordenação relações transferenciais distintas que não se fixam, são contatos flexíveis e em sua maioria impessoais, e parecem ocorrer num substrato invisível de confiança sem personalização. Evidentemente, o que caracteriza a heterogeneidade deste funcionamento não é a diversidade de situações diagnósticas, nem a formação profissional distinta, mas o próprio modo de proceder, de dispor estes elementos de maneira a intensificar sua heterogeneidade o dispositivo, em suma.

Talvez se possa afirmar, no caso deste Ateliê Experimental, que se trata de um dispositivo clínico que efetua aproximações: da equipe com o grupo; de cada um dos integrantes entre si e com os possíveis funcionamentos do trabalho; dos modos de ensinar, propor, acolher. Num dos encontros, contamos a história da 'Cortina da Tia Bá' de Virgínia Woolf, e cada um devia definir qual o personagem a fazer. Formaram-se grupos de elefantes, de macacos, de sapos e de anões. Alguém devia roncar três vezes e todos então se moviam. Outros três roncos e todos paralisavam novamente. Era uma cena de jogo, muitos risos aconteciam e os corpos se tocavam de modo casual, mas todos se estranhavam. Não era um teatrinho o que fazíamos. Talvez, um exercício de contato: entre peles, olhares, dos possíveis modos de se mover. Houve quem não 
pertencesse a nenhum grupo, permaneciam sentados e observavam atentamente, até um pouco assustados. Depois disso, em encontros subseqüentes outros exercícios propunham que desenhassem personagens desta e de outras histórias. Depois de recortar seus contornos, prendê-los em palitos, o convite era para inventar histórias. Uma delas foi "A guerra do leite": um rio de leite onde bichos e homens vão beber e onde começam a disputar terrenos da margem. A história não tem um desfecho, cada um com seu boneco tenta retrucar com frases cortadas, balanços do palito procurando um som, silêncios constrangidos por não encontrar o que dizer para enfrentar aquele proposto combate... A história acaba quando ocorre uma dispersão dos manipuladores dos palitos: de repente, já não temos mais ninguém à beira do colchonete que formava o rio de leite, a guerra não existe mais, e nem os sinais de que ela existiu ficam ali, cada um recolhe seu boneco, um vazio, o rio de leite é o deserto. O futuro destas experimentações desdobraram-se em pequenos filmes com bonecos e com os próprios participantes, em stop-motion - técnica de desenhos animados que monta os deslocamentos por sucessão de fotogramas, selecionando e eliminando o que faz o objeto-personagem se mover. "É mágica", explica um dos participantes.

Ao observar a adesão às atividades propostas com surpreendentes e precisos manejos dos materiais e ferramentas a partir de poucas instruções, e o empenho concentrado para concretização de objetos (a maioria sem planejamento) é possível reconhecer uma espécie de confiança no dispositivo, aquela ambiência insólita aparenta ser um mundo creditável. Ambiência insólita, considerando por exemplo que as designações verbais que anunciam as propostas de atividade têm pouca eficácia - uma vez que se trata de um grupo com comprometimentos nos aspectos da compreensão oral e escrita, isto exige da equipe de coordenação, um acompanhamento corpo a corpo para a maioria dos participantes durante todo o 
processo. Então, o que mais faz funcionar ali é o estar-junto de cada um com cada outro.

De um modo geral, ocorre a construção gradativa de uma disponibilidade tanto para os trabalhos no ateliê (momentos de silêncio e concentração para a apresentação das propostas, para escuta das histórias e dos comentários alheios, considerando até mesmo os grunhidos; quanto para os trabalhos com o corpo (tirar os sapatos, mudar de posição - em pé/sentado/deitado); a exigência de maior duração e poucas variações com necessidade de muitas instruções com toques, demonstrações e visualizações, além de algumas adaptações. E o caráter experimental retorna, ou coexiste nestes exercícios, através de gestos ousados, construções deformadas e momentos de contato privilegiado e inéditos: olhares, sorrisos, brincadeiras e toques que passam a ser percebidos e desejados como sinal de uma apropriação daquelas vivências coletivas.

Os aspectos da convivialidade perpassam todos os momentos, e apresentam-se como uma das linhas prioritárias. No entanto, há momentos dedicados exclusivamente a esta perspectiva, ao encontro dos elementos deste coletivo: a chegada e as refeições conjuntas, as esporádicas saídas grupais - seja para visitas a exposições ou execução de propostas do ateliê e dos trabalhos corporais em ambientes externos à sala. Aí ficam evidentes as conversas e o deslocamento corporal dissonante que desdobram-se e se somam às dificuldades de acesso e presença em determinados locais, bem como à necessidade de construir um olhar abrangente, em conexão. Quando, por exemplo, assistíamos ao vídeo de demonstração dos procedimentos de um artista, ficou flagrante a impossibilidade de acompanhar o encadeamento das cenas e formar qualquer entendimento, em função, principalmente da velocidade videoclíptica das imagens, o que era visto estava longe de ser o previsto. Mesmo com algumas estratégias de preparação e sensibilização (contar histórias sobre os lugares, mostrar livros, desenvolver oficinas 
com procedimentos próximos...) pensadas e implantadas, que estimulam o levantamento de questões possíveis e incentivam associações, ainda que esparsas, a saída é sempre intempestiva, na ida e na volta, não há compreensões que se fecham, e fica tudo aflitivamente aberto, sem nos devolver qualquer sinal explícito sobre a validade daquele deslocamento. Qualquer suposta preparação ou reflexão posterior parece constelar um universo à parte, nada contíguo ao que esteve ou está por vir. Depois, algumas redes frágeis se compõem, pistas de que valeu à pena, sinais sutis, quase invisíveis, perceptíveis no modo de seguir vivendo juntos, só aí as continuidades se esboçam. Sinais como os de quando alguém lembra uma marca surpreendente do local (portas que se abrem automaticamente); quando alguém sabe o nome de um monitor, ou de alguém do próprio grupo de quem esteve perto aquele dia, ou até mesmo quando alguém resolve perguntar o nome de algum outro; quando alguém se atrasa e consegue nos encontrar diretamente no local agendado sem que o tivéssemos preparado para isto; quando alguém entrevista um outro: 'Como chama teu pai? E tua mãe?; 'Teu pai tem cabelo? E tua mãe, tem cabelo?'; quando alguém traz uma comida que outro alguém gosta. Tudo muito pequeno, aparentemente, mas muito sensível e sutil, sobretudo porque não programado.

Os momentos de refeições coletivas são atividades cuidadas por todos em todos os seus passos. E, a cada vez, as etapas decididas coletivamente se acrescem: escolha do cardápio, distribuição dos ingredientes (ousadia, pois a falta de algum deles nos coloca em situações complicadas!), o envolvimento com a preparação da comida, da mesa, a espera para comer junto. Já foram feitos sopa, pizza, cuscuz, macarrão, farofa de carne seca, yakissoba, sorvete, lasanha. Cada um contribui com o que lhe é possível. Um dia, a mãe de um dos participantes trouxe uma lata de molho de tomate e queria entregar escondido dele, apostando que ele faria um escândalo, 
como de costume faz nos supermercados e em sua casa, impedindo o uso do alimento. Insistimos que ela the deixasse levar, e num gesto que denotava um entendimento sobre o motivo daquele alimento estar ali, ele o trouxe até a cozinha e o entregou ao grupo que preparava a refeição. Mais que qualquer treinamento ou adestramento para esperar o alimento ficar pronto, aguardar até que todos estejam à mesa, saber comer em porções pequenas para dividir com os demais e uma série de outras pequenas acomodações que foram necessárias ser feitas, o que se sobressai nesta experiência é o aprendizado da noção de festa. Festa como um lugar não compulsório, que em sua subitaneidade desajusta as posições habituais, desarranja as formas usuais admitidas ou esperadas socialmente. Um evento fora do ritmo de vida rotineiro, algo que se inscreve na dimensão do prazer, desconhecida para muitos deles, ou só conhecida de um modo primário em masturbações e empanturramentos. Paulatinamente, a festa destes jantares coletivos, ainda que inscrita no espaço institucional relacionado ao tratamento, apresenta momentos de alegria desejados e esperados por cada um de todos. Diferente dos outros dias, neste a circulação é muito mais livre: ora picar os ingredientes, ora dançar, ora lavar a louça, ora beber e beliscar lascas de algum petisco, ora exercitar pequenas transgressões (brindar um pouquinho de vinho ou de champanhe; pegar um pedaço do queijo ou das azeitonas do prato principal, jogar as panquecas para o alto, sacudir a travessa de lasanha, fingir que tudo queimou...), brincadeiras desconhecidas ou totalmente impedidas no universo de quem cresceu privado de experimentar-se, adestrados em mundos previsíveis e inócuos. Quando se apercebe que esta festa é possível, fica sinalizado que algo escapou à assepsia a que se está quase sempre condenado, e produziu este encontro ali, em meio ao ruído e à lambuzeira freqüente neste projeto. Do desespero inicial com a pasmaceira e a apatia, o projeto foi lançado numa devoração coletiva, apresentando por muitos 
lados uma ânsia pelos momentos de reunião, transformando-se num ponto de encontro.

Inevitável pensar que a invenção deste dispositivo é caudatária das experiências das artes, sobretudo das vanguardas modernas. Experiências que buscaram reaproximar arte e vida, no tocante aos comportamentos cotidianos, aos modos de cuidar da vida em comum. Quando um artista, como é o caso de Hélio Oiticica, procede com o objetivo de aproximar "manifestação criativa e coletividade" (FAVARETTO, 2000, p. 129) como no processo do Programa Ambiental ou Parangolé, cuja "tendência básica é transformar a arte em outra coisa; em 'exercícios para um comportamento', operados pela participação" (FAVARETTO, 2008, p. 21), ele inaugura a possibilidade deste procedimento, e inscreve com seu gesto, um modo de questionar aquilo que no social investe segregações sejam de ordem financeira, intelectual, social ou outras. Estes questionamentos são heranças relevantes para a clínica com estas populações de que trata, por exemplo, o projeto do Ateliê Experimental, o que justifica uma aproximação com os pontos fortes destas artes de ruptura.

[...] renovação de comportamentos, de critérios de juízo, etc., passa pelo modo de produção aliando conceitualismo, construtividade e vivência $[\ldots]$ originam conjuntos heteróclitos, em que processos artísticos e culturais diversos são justapostos e, como efeito da devoração, reduzidos a signos que agenciam ambivalência crítica e exploram a indeterminação do sentido, propondo-se, assim, como ações que exigem dos participantes a produção de significados. (FAVARETTO, 2008, p.21)

Em sua circunscrição no tempo (considerando que embora as pessoas fiquem muitos anos conosco, não é para sempre!), o entendimento daquilo que é oferecido por projetos como o do Ateliê Experimental, deve fazer-se no sentido de um lugar de vida, de experimentação. No dia-a-dia do projeto, a possibilidade de efetivar a potência desse desejo de estar junto é um sinal de alegria, bem como de preocupação. Semanalmente inventamos nossas atividades. Eventualmente temos a festa. Festa como um elemento raro, fora da rotina. Para alguns modos 
de viver, cabe tê-la em abundância, entretanto para outros ela é uma carência. Uma falta de que não se sente falta, por sequer conhecer o que falta. Insistir nesta direção ao engendrar sempre que possível estes momentos de festa nos coletivos, em meio a muitos encontros vivos e outros mais enfadonhos é uma maneira de achar lugares onde se possa desejar outras coisas, que efetivamente aumentem a sensação de existir e pertencer a algum ou alguns mundos, ainda que isto possa nos transportar ao risco de um procedimento idealizado da clínica, na tentação do transbordamento, no fascínio da loucura, na sedução da fragilidade marginal, numa viagem hedonista qualquer, numa hybris... Mais uma vez, é indispensável referir a aproximação, ainda que tímida, deste modo de proceder e pensar do projeto, com aquele abarcado por algumas experiências artísticas modernas.

Prática revolucionária, a transmutação da arte em comportamento se dá quando o cotiano é fecundado pela imaginação e é investido pelas forças do êxtase. Surrealizados, os comportamentos libertam as possibilidades reprimidas; afrouxam a individualidade, confundem as expectativas: manifestam poder de transgressão. (FAVARETTO, 2008, p. 21-2).

$\mathrm{Na}$ esteira dos riscos desta aproximação das chaves do pensamento das artes, outro perigo é o de que quando atribuímos à equipe a condução desta situação "micro revolucionária" é já um modo de pensar pragmático que se está elegendo, que muitas vezes os processos clínicos exigem, mas que não devem suprimir a dimensão soberana do acaso. É fato que a coordenação do projeto do Ateliê Experimental, bem como a do próprio serviço de extensão - PACTO - de modo ampliado, está debruçada em encontrar modos de fomentar estes eventos, de fazer dos encontros deste projeto algo potente aos participantes e aos estudantes, e que se desdobre em enunciações de referência para o campo da terapia ocupacional, para o da clínica e para o das artes também. Entretanto, o acaso que se faz de pequenos movimentos, mais pra lá, mais pra cá, de cada um dos elementos 
que justapõem-se para um acontecimento é o responsável pela abertura do trabalho, este é seu dispositivo. Elementos como aqueles que definem, por exemplo, que os atendimentos do grupo ocorreram no prédio capenga das salas de aulas dos estudantes da universidade e não nas salas do prédio instituído como sendo da clínica do curso, onde os movimentos são mais padronizados na relação com as pessoas atendidas. É tenso saber que um professor está em aula enquanto um dos participantes está gritando no corredor, no entanto é indubitável o quanto esta perturbação interfere positivamente na formação de um terapeuta, assim como aquela que faz com que hajam conversas coletivas entre os estudantes e os pacientes sobre futebol, novela, greve, na recepção do prédio, e que eventualmente alguém convide um dos pacientes para comer um pastel ou para jogar pebolim no centro acadêmico ao lado. São misturas estranhas, incômodas, mas constitutivas de uma matéria plural que não se desdobra em sucesso, nem em nenhuma totalização ou evento absoluto.

Há que se considerar a existência neste ajuntamento, e provavelmente, de outros modos, em outros de mesmo tipo, de uma constelação irrefutável de forças que favorecem em conjunto estes acontecimentos. E isto nos leva a indagar sobre qual saúde faz com que dentre tantos portadores de deficiências, loucos, velhos, terapeutas, artistas, estudantes, etc, justamente estes se encontrassem num determinado ponto, e fossem responsáveis por fazer acontecer num acontecimento corriqueiro como o de um serviço de saúde, algo desta natureza. Alguma coisa desandou no cozimento, algumas linhas escaparam às formatações pressupostas do receituário social, algo transbordou a fôrma, queimou um pouco, outro pouco cresceu...

Alguém quer repetir? 


\section{EXPERIMENTO II}

\section{Circunstância e improviso}

A vitalidade da cia. teatral Ueinzz ${ }^{20}$ advém substancialmente da importância que se dá aos seus traços culturais e artísticos. Ela é um grupo de teatro ${ }^{21}$ constituído por atores com passagens, maiores ou menores, em serviços de saúde mental, com vivências de sofrimento mental marcantes em suas trajetórias de vida. A prioridade dos aspectos artísticos e culturais deste projeto é sua ação política. Ela coincide com a relevância da clínica que o atravessa e sustenta e que está inteiramente dedicada e à serviço desta priorização. Em termos de visibilidade, as propriedades artísticas predominam, entretanto elas só adquirem este destaque pela capacidade da clínica que a afiança, cuja atuação é colateral, nos interstícios, e embora incessante e sempre à espreita, busca ser discreta, quando possível, invisível. No âmbito mais estrito, as extensões clínicas que o projeto alcança na vida dos atores da cia. são tomadas como decorrências, junto a tantas outras, algumas

20 O nome da cia., "Ueinzz" - cuja grafia se estabeleceu assim depois do ensaio de muitas outras possibilidades -, surgiu em meio a um exercício cênico em que os atores eram interrogados sobre as línguas que sabiam falar, ao que um deles surpreendeu a todos respondendo que sabia falar alemão "E que palavra você sabe em alemão? Ueinzz... E o que significa Ueinzz em alemão? Ueinzz. Todos riem - eis a língua que significa a si mesma, que se enrola sobre si, língua esotérica, misteriosa, glossolálica." (PELBART, Peter. Ueinzz - viagem a Babel. In: PELBART, Peter. A vertigem por um fio. São Paulo: Iluminuras, 2000, pp. 99-108.)

21 A cia. teatral Ueinzz existe desde 1997, e é coordenada por uma equipe de terapeutas de formações profissionais heterogêneas: Ana Carmen Del Collado (assistente social e psicanalista), Eduardo Lettiere (psicólogo e psicanalista), Erika Inforsato (terapeuta ocupacional), Paula Francisquetti (psiquiatra e psicanalista) e Peter Pál Pelbart (filósofo e professor de filosofia). A direção artística do grupo foi conduzida, inicialmente, por Renato Cohen e Sérgio Penna, e, desde o ano de 2007, está sob os cuidados de Cássio Santiago com a colaboração de Elisa Band e colaboração cenográfica de Simone Mina. Além deste núcleo permanente, muitos outros técnicos e artistas (músicos, atores, figurinistas, cenógrafos etc.) estão ou estiveram ligados ao trabalho da cia. teatral Ueinzz em função de cada projeto e/ou temporada, destes, cabe destacar a artista Alejandra Riera, que tem desenvolvido o projeto "Enquete sobre o/nosso entorno", em parceria com a cia., desde o ano de 2005. 
apreensíveis e outras mais impalpáveis, mas evidentemente efetivas.

Impossível de constelar em formas e menos ainda em metodologias, esse encontro das artes com a clínica, neste projeto e em outros de mesma linhagem, ficam numa zona indiscernível. A dimensão cultural da experiência da cia. teatral Ueinzz situa-se no empenho de sua escuta das forças e das diferenças, aquilo que força o pensamento a pensar, a violência que convoca o pensamento às convenções e do mesmo modo às direções insuspeitadas. "Aquilo que a lei atinge, proscreve ou perverte é a cultura, é o que se pensa da arte, são os hábitos históricos, é o curso do mundo, são os livros e os museus, por vezes os artistas, mas por que escapariam eles à violência?" (BLANCHOT, 2005, p. 39). Se a clínica é aquilo que se debruça em ver e fazer ver, em escutar e fazer escutar, em falar e em fazer falar o outro, essa concepção de cultura está conectada a ela, em seus protocolos e em suas invenções de mundos. É em função também dessa aliança com o campo das artes e da cultura que a cia. teatral Ueinzz existe e resiste, pois ela favorece, muitas vezes, uma convivialidade, que é o que mantém este coletivo há mais de 10 anos juntos. No escopo destas percepções a dimensão clínica deste dispositivo, configura-se pelo trabalho da equipe de terapeutas que acompanha este grupo. Para abordar esta clínica muitos viéses são possíveis: de sustentação na construção e na apresentação de cenas, de mediação das relações entre os atores, deles com a direção artística; de viabilização das experiências de apresentação pública, de mediação no contato com outros fazedores de arte, de manejo das medicações, de negociação com os familiares; de preparação para as distâncias concretas, para os deslocamentos das viagens - que acabaram por ser muitas, nesta trajetória (Curitiba, Porto Alegre, São Carlos, Campinas, Santo André, Fortaleza, Crato, Belo Horizonte e Rio de Janeiro - no Brasil; Les Mans - na França; Kassel - na Alemanha; e Helsinque - na Finlândia). 
Do lugar de terapeutas, o acompanhamento de um grupo com esta singularidade, ocorre uma convocação a um exercício clínico radical (de escuta, localização de questões relevantes, intervenção, interferência, abstinência, acolhimento e continência, de interdições de inevitável violência) para impedir que cada um responda num lugar exclusivo de doente, deficiente, invalidado. É necessário ser muito terapeutas para que aqueles possam ser outras coisas que não só pacientes, e possam deslocar-se da condenação a uma identidade única e absoluta, que os força a manterem-se sempre os mesmos, e nunca poderem ser outro, muitos outros, devir. Isto exige vizinhanças intensas, invoca a alteridade do próprio terapeuta para estar e fazer junto: um tanto atores, agenciadores, arremedo de produtores, preparadores corporais, assistentes de direção, aspirantes a performes.

Neste convívio muitos agenciamentos justapõem-se cotidianamente: risos, improvisos, pesquisas, brigas, deslocamentos, invenção, convites, interrogações, surpresas, decepções, excitação, estranhamento. Tanto as fecundidades quanto as complicações são acompanhadas pela equipe de terapeutas.

Conversas, passeios, brincadeiras, ensaios, viagens, recolhimentos, sono, sumiços, cenas, gritos, comidas. Alguém não toma o remédio por três dias, inverte a medicação da manhã com a da noite, oferece comprimidos uns aos outros, à equipe técnica que quer sentir uns "baratos" (numa das viagens eles cantavam o "melô do Akineton"); uns fazem xixi na calça, espalham cocô pelo banheiro do hotel, outros somem em meio à multidão, saem dar uma volta sem ter orientações concretas para retornar; fazem mímica com sons guturais para que a recepcionista alemã entenda que a descarga do banheiro do quarto quebrou; consomem toda a comida do frigobar sem dinheiro para pagá-la; ameaçam jogar cadeira no colega que 
passou a mão na sua bunda; jogam na loteria da França; saem correndo para tomar o barco para a cidade e nos deixa esperando por uma hora até chegar o próximo barco; invadem a cabine do piloto; se emocionam com um texto de Artaud lido em francês sem saber a língua...

Pela necessidade de pensar nesta clínica - este aspecto pouco discernível do projeto -, vale dar visibilidade a sua translucidez. Através de um amontoado de descrições, esboçamse figuras em imagens do que seriam os personagens desta clínica do teatro ou deste teatro da clínica, incrementando uma possível discussão desta experiência na cia. Ueinzz.

... um homem jovem - o pai está doente com um câncer avançado e ele atado a esta configuração familiar fragilizada com a madrasta e uma divisão de bens conflituosa, vive uma antecipação da morte do pai... anda às voltas com um processo de interdição movido por ele mesmo, na prática, e pela irmã, na burocracia... e a cada perícia ele se angustia... antigo na companhia ele tem acesso aos celulares de alguns dos terapeutas e faz telefonemas ininterruptos, numa espécie de arrastão pela equipe - liga para um diz que falou com o outro e que vai ligar para um terceiro, e que um outro não the atendeu... pede para que os ensaios sejam alternados, a cada quinze dias, porque ele sai dali "muito cheio de amor e a vida lá fora é dura..."; pede que visitemos uma exposição juntos - toda a companhia, no final de semana... diz estar apaixonado por uma das terapeutas, acusa os terapeutas de intelectuais e declara que sonha ser professor de história... tem um senso de humor muito agudo, nos indaga com força sobre como fazemos a nossa vida funcionar - trabalho, estudo, dinheiro, amores...; propõe fazer "satisfação corporal" que são exercícios de abraçar, toques, massagens vigorosas, rápidas!... manifesta desejos de estender a convivência e a proximidade. É um ator importantíssimo para a cia., pelo arrojo 
de suas improvisações, por sua intempestividade em cena... Rasga uma conversa com uma pergunta do tipo "Qual o sentido da vida?" Vai sempre ao mesmo cinema, no dia que é promoção, acompanha as críticas, lê com dificuldade "Nitz", Freud, Lacan, a Psicanálise é referida freqüentemente em associações com a religião. "Oremos irmãos!" - subitamente ele grita, e atravessa as cenas...

... uma mulher jovem - imatura. Foi apresentada como portadora de um problema "neurológico", com um comprimido para as supostas "convulsões", que aos poucos foi possível entender tratarem-se de 'convulsões do espírito' num corpo extremamente impedido e cheio de energia, de libido. Suas entradas em cena são etéreas, frases súbitas, ecos do que pode haver de mais clichê em relação aos sentimentos, gestos desajustados com trejeitos de uma delicadeza imitada e genuína. Ela pergunta todos os dias se o grupo vai acabar, e no início chorava, e então convulsionava depois de conversas sobre alguns problemas com o grupo tais como apresentações desmarcadas, financiamentos adiados, falta do diretor etc. Também se contorcia quando recebia toques no corpo dos homens do grupo, até numa pequena dança de par já aconteceu... Em viagens, passamos horas com ela pendurada em nossos ombros chorando e se contorcendo em silêncio. E mais ataques no hall do hotel, se jogando no chão, no meio da rua, pendurada nas pernas de um dos terapeutas, empurrando qualquer outra pessoa que se aproxime. No restaurante não pode ver ninguém tomar leite; tem medo de atravessar a rua sozinha, escreve bilhetes e histórias de uma cidade chamada Esperança (uma espécie de novela romântica misturada com conto de fadas - com princesa, pessoas boas e muita paz...). Numa das últimas crises , enquanto tentava conversar e ao mesmo tempo procurar o tal "remedinho" na bolsa dela, eis que um estojinho com balas de menta surge antes, perguntada se queria uma bala, ela conseguiu dizer que sim, 
chuparam a bala, ela e eu, para ficarmos iguais, e logo as contorções cessaram: mais calma, foi ao banheiro e voltou despedindo-se e agradecendo. A insistência da equipe é para que ela fale, em lugar de contorcer-se. Ela tenta. Em cena e fora da cena. É de uma tenacidade admirável, convicta nas palavras, sua fala é como uma leitura decorada improvisada, uma declamação ímpar.

... um outro rapaz jovem - tem um problema na visão, resultado de uma leptospirose na infância, se relaciona com a deficiência como uma experiência totalizadora, coleciona vivências de exclusão e expulsão, e reivindica esta chave todo o tempo, criando situações limite, com reações agressivas às brincadeiras, e diz que já sabe que não é mais para ele vir... Então pede para ser expulso o outro, seu suposto inimigo no conflito e é todo um exercício diário para esclarecer que o grupo não funciona assim, que tem que caber todo mundo e cada um que chega não ocupa nenhum outro lugar senão o seu próprio. Tem uma relação muito especial com o rádio, e muitas informações, dados sobre generalidades, que vai ditando a cada oportunidade, o que cria sensações insólitas, que ora aborrecem e ora fazem rir, passou a dançar e a cantar em cena, com trejeitos escandalosos, ávido por aplausos.

... um terceiro rapaz muito jovem - um garoto, viril, com uma corporeidade de leão enjaulado, pulsando energia... ele passa todo o tempo em rondas... participa de algumas atividades e se retira, roda, roda, roda, retorna, ou não retorna... escapa, foge e quando reaparece (ou capturado, ou fracassado na fuga que ele não sabe bem de quê), se domestica, espera castigos e represálias infantilizadoras e todo chamamento para atitudes mais amadurecidas, horizontais, são entendidas como espécies de humilhações... Depois de muitas situações deste tipo tem se aproximado do trabalho e experimentado coisas menores, com 
intensidades mais sutis, diferentes das que ele buscava com bebida e outras substâncias entorpecentes. Fica muito mobilizado com as possibilidades de trabalho com o teatro, e quer cumprir com uma função imaginária que parece muito o estereótipo do "alternativo" e com isto se coloca em situações de risco e muitas vezes não consegue participar dos momentos conjuntos. Seus deslocamentos são sensíveis, movem-se no sentido de um redimensionamento, de encontrar um tamanho e um jeito de estar e fazer teatro, e de viver, que não arrebente o entorno.

... uma mulher mais velha - e ser mais velha tem sido um grande problema. Muito inteligente e sagaz diz que "briga com o tempo que passou". De um talento sem precedentes, faz improvisos e cenas perturbadoras em intensidade e precisão artística. Algumas crises mais agressivas e intransigentes se disparam em função especialmente de alguma dificuldade na apreensão do que está acontecendo ou do que ela supõe estar acontecendo e que não está sendo dito a ela ou explicado suficientemente, ou que ela julga não ter capacidade para entender. É muito sensível ao movimento grupal, e tem muita dificuldade com a vizinhança borrada com a equipe de coordenação. Acusa: "vocês tem que cuidar disto porque estão do outro lado do balcão". Em outras ocasiões, aproxima-se de um modo delicado e exige reciprocidade, as situações complicadas que eclodem são recebidas como inadmissíveis e insuportáveis, não podem escapar e tem que ser evitadas. Em geral se retrata, e volta a crítica feroz a si mesma, explicando que com isso reconhece que espera que os terapeutas sejam "deuses".

... outra mulher mais velha - uma senhora inquieta, e que traz essa agitação para a cena, criando momentos de muita estranheza, movimentos quebrados, como em soluços. Insiste em dizer que suas coisas fugiram do lugar onde as pôs, inclusive 
o ensaio, é como se ela inscrevesse cada coisa num terreno extremamente restrito e qualquer extravasamento fosse entendido na desconfiança, alguém o faz para prejudicá-la, marca outros horários, propõe trabalhos diferentes, solicita desdobramentos, muda sua bolsa de lugar, esconde ou rouba suas coisas para provar que o teatro não é possível para ela... Vive um sonho frustrado, sabe como gostaria que fosse, tudo bastante idealizado e se relaciona com o fracasso disto, do que ela não pode mais aprender, não pode mais ter: boas transas, ser boa atriz, estar num grupo de normais, no máximo "depressivos".

Estes são alguns... Como mencionado antes, o trabalho clínico que se faz na companhia visa impedir que o tratamento se fixe como um lugar central em suas vidas, é uma espécie de catapulta, com os riscos que pode haver num alçamento deste tipo. Talvez a diferença seja que o terapeuta-lançador também se coloque na "baciazinha" de lançamento, e parta junto nesse vôo arriscado. A aposta é de que possa haver outros modos de relação e de sensibilidade na vida de cada um e na da companhia. Na experiência longa do grupo observa-se o quanto isto permite desvios da condição de paciente, tão presente em suas vidas, e para onde, sem esse empuxo, eles tendem a retornar a cada instante. Este é o combate instalado: inventar jeitos para que possam ser portadores de outras experiências em suas vidas.

Sempre que se junta, o grupo, não é a possibilidade de bastar-se, como um eu adaptado às circunstâncias sociais que define a presença neste conjunto, quem é capaz de ser um $e u$, exerce esta capacidade, e pode experimentar afrouxá-la, enquanto os que não têm esta capacidade, não a empregam, e podem apoiar-se num terreno firme, independente de estrutura de ego/eu/self ou outra nomeação que se possa propor. 
Somos juntos e só aí, ou assim, podemos dizer "eu": eu não diria "eu" se estivesse só (outra versão: nós não diríamos "eu" se nós estivéssemos só(s)...), pois se eu estivesse só não teria nada do que tivesse que distinguir-me. Se me distingo se nos distinguimos - é que somos vários [...] (NANCY, 2003, p. 17).

Surpreendentemente, ocorrem entendimentos afetivos, que prescindem de uma organização intelectual padrão. É indecidível a condição desta clínica, transversalizando este território Ueinzz pois, na medida em que ela se faz presente com grande intensidade, poderia-se pensar que ela motiva e até mesmo sustenta a existência do projeto, por outro lado, a existência de um tal projeto permite que esta clínica se presentifique com tal singularidade, constelando sua circunstância recíproca. Sem determinar as fontes originárias, com efeito, o que se vive é algo suficiente para marcar que se está vivo, algo que garante uma existência, ainda que não garanta continuidades, e cuja gestação se dá numa zona indeterminada. Dispõe-se de anteparos inomináveis, que desenvolvem capacidades mínimas, cascas que sejam, para conviver com circunstâncias violentas e opressoras, podendo não as assentir e sobreviver a elas, desviar-se delas, sem que isto dependa de sua supressão para resistir e existir de outro modo. 


\section{La Fonderie - Casamento de campanha ${ }^{22}$}

É evidente a quem trabalha com a loucura, no campo da saúde mental, que as repercussões que a participação num projeto como da cia. teatral Ueinzz produzem na vida de seus integrantes relaciona-se com sua efetividade clínica, embora sua proposição declarada seja artística. A presença e a disponibilidade dos terapeutas neste projeto faz com que pessoas com atravessamentos significativos da loucura - de dor, desorganização, ritmos transtornados, forças de desertificação possam produzir sentidos num coletivo, em função de uma arte, o teatro.

Este motivo, o teatro, enfatizado como elemento de reunião deste coletivo, paulatinamente coloca a cia. em situações em que esta temática se abre de tal forma que fica difícil reconhecê-la como um porto seguro: fazer teatro leva a experimentações insuspeitadas que muitas vezes, surpreendem a todos.

Em meio a esses espantos, em outubro de 2005, a cia. teatral Ueinzz recebeu um convite inédito: uma cia. de teatro da França, chamada Thêatre du Radeau (que traduzindo seria algo do tipo "teatro da jangada"), convidou a cia. Ueinzz para uma temporada de convivência, pesquisa e invenção num espaço cultural de gestão e coordenação deles, chamado La Fonderie. Infelizmente, não podiam convidar a todos do grupo, pois apenas tinham recursos para financiar a viagem de sete

22 A tradução "casamento de campanha" pareceu fazer jus à expressão francesa "mariage dans la campagne" adotada para designar em forma de brincadeira o acontecimento principal desta narrativa, ela refere-se ao modo tradicional de casar daqueles que residem no campo, nas regiões distantes dos centros urbanos na França. No Brasil, esta expressão é utilizada no mesmo sentido em alguns estados, principalmente da região sul, mas há outras designações de sentido aproximado em língua portuguesa, usadas em outras regiões do Brasil, tais como "campo", "zona rural", "interior" etc que preferimos não utilizar. 
integrantes. O número de integrantes da cia. Ueinzz gira em torno de 21 pessoas, sem contar a equipe técnica. E com esse convite restrito a sete, a distribuição mínima pensada foi de dois terapeutas, o diretor e mais quatro atores escolhidos pelo diretor em função da possibilidade de uma configuração artística que favorecesse a construção de cenas, fragmentos de um espetáculo, como havia sido proposto.

Muitas situações novas daí decorreram. Em primeiro lugar, nunca antes a cia. tinha sido convidada para uma viagem internacional, o que era motivo de grande excitação e interrogação sobre sua potência para fazer jus ao desafio. Em seguida restava ainda lidar com uma separação que, na prática, implicava que uns teriam a experiência diretamente e outros não a teriam, ou a teriam de forma indireta, pelos registros e narrativas que os outros conseguissem trazer e fazer. Além disso, a natureza do convite não pressupunha a apresentação de espetáculo, o que também provocava estranhamento. Todas estas complicações foram, como em outras tantas vezes, acompanhadas pela equipe de terapeutas.

A cada vez que o grupo recebe um convite para apresentação, é uma espécie de "ressurreição" o que se constela, pois, em geral, o grupo passa muitos meses arrastando-se em encontros para espera conjunta de algum convite. As entressafras são longas, o que intensifica a alegria e a excitação na recepção de cada convite. E então é uma correria absurda: remendar figurinos, fazer outros novos, comprar maquiagens, conferir documentos, lista para fazer as malas, medicações, telefonemas, contatos com familiares etc.

Bem, no caso da viagem para a França havia um elemento convergente dessas complicações: o passaporte. Ele aglutinava em si uma quantidade de signos da viagem que foram motivo de muito trabalho. $\mathrm{O}$ passaporte parecia marcar concretamente a distância, a extensão da viagem a ser feita. 
Dessa relação com o passaporte decorre uma narrativa, uma maneira de alinhar e ao mesmo tempo expandir os eventos desta experiência, de modo a contribuir com a pesquisa sobre o trabalho clínico realizado com este grupo e os deslocamentos esperados.

Os atores escolhidos para esta viagem para a França eram quatro, como já mencionado, duas mulheres e dois homens; dois mais novos (em torno dos 30 anos) e outros dois mais velhos (em torno dos 60), todos atores com um histórico de apresentações com a cia. que indicavam para o diretor, e reconhecidamente para a equipe de coordenação, capacidade de improvisação, exploração do espaço cênico, dramaticidade, presença intensiva em cena. Sem dúvida alguma, uma ótima amostragem do grupo de atores, o que não impediria outras, tão boas quanto esta.

Quando da comunicação deste recorte ao grupo, a equipe supôs que ele seria vivido de uma forma traumática, mas foi surpreendida com indícios de uma sobriedade criteriosa, uma confiança, advinda, provavelmente, da força da experiência comum que prevalecia sobre os milhares de narcisismos que aparecem muito e que são administrados o tempo todo, inclusive os da própria equipe de terapeutas.

Então, de volta aos atores selecionados e à história com os passaportes: desses quatro, o ator mais velho, só pegou seu passaporte três dias antes da viagem. Foi uma longa negociação acompanhada especialmente por um dos terapeutas da equipe, que implicou um extenso processo de convencimento nos encontros do grupo, em inúmeros e picotados telefonemas, até ir a sua casa, prepará-lo para sair, ajudá-lo a procurar seus documentos e oferecer continência a uma série de lembranças que iam sendo lançadas à mesa junto com os papéis guardados. Depois, levá-lo até uma loja para fazer fotos, preencher o formulário com dados que aparentemente são automáticos mas que para ele exigiam relacionar-se com memórias duras - por 
exemplo, ao preencher o item "estado civil", um deles conta que é viúvo e segue dizendo que fora casado e que sua esposa se matou e todo o drama da situação sobrevém ao que seria um mísero "xisinho" -, e aí então acompanhá-lo até a Polícia Federal e solicitar o passaporte. Em seguida, outra série de telefonemas diários onde anuncia todas as suas vivências corporais, escatológicas, memoriais, premonitórias de sua morte etc etc. E mais, depois, todo o caminho de volta para buscar o passaporte pronto e encaminhá-lo às pressas para o consulado que, muito generosamente (e em função de uma série de contatos telefônicos) concedeu o visto sem que tivessem que se apresentar pessoalmente e no prazo recorde de 1 dia.

A atriz mais nova, foi a primeira a fazer seu passaporte. Fez. Foi para casa e tomou uma quantidade de comprimidos que teve que ser hospitalizada. Sem tempo para uma lavagem gástrica, ficou dormindo e letificando com aqueles remédios até os primeiros dias da viagem, que ela ainda assim o fez, obviamente, em função de uma série de contornos oferecidos pela equipe: várias conversas telefônicas, tentativas de marcar alguns encontros, e como não comparecia, uma visita até sua casa para organizar os passos finais para que ela conseguisse participar da viagem, conversas sobre a relação com o filho adolescente que ficaria sozinho, o irmão que fora internado, as amigas do partido político que emprestaram roupas e a máquina fotográfica que na volta ofereceu importantes registros da viagem para serem compartilhados com todos.

Já a atriz mais velha, teve a sorte de ter duas irmãs que engataram totalmente na sua viagem e tomaram para si as tarefas de prepará-la como se estivessem preparando a si mesmas para viajar. Dias arrastando um corpo cansado, uma voz embargada, sempre chorosa ao telefone, enfim numa fina linha ela se sustentou, fez o passaporte, as malas. Esqueceu os óculos no dia da viagem, o que fez com que uma de suas irmãs fosse até o aeroporto, minutos antes do embarque. 
Enfim, o ator mais novo, cuja história será aqui mais detalhada. Um rapaz muito vivo. Autor da ideia de se fazer um grupo de "teatro de verdade" - como ele disse na ocasião. De certo modo, o principal fundador da cia. teatral Ueinzz.

Bem, ele esteve presente em todos os momentos da preparação da viagem. Vinha aos encontros, me telefonava todas as noites, deixava recados dizendo que não ia mais, depois retornava, voltava atrás, muitas vezes, dias a fio. Indagava a equipe com questões extremas. Algumas intrigavam, pois questionavam a própria oportunidade, o acontecimento, o convite, sua imprecisão e formato:

- Por que eles querem que a gente vá até lá?

- Eles pensam que a gente é índio?

- O que eles querem com a gente? Ver que a gente é louco?

- Por que eu? Leva ele (e apontava um outro ator) ele sabe falar melhor que eu. Eu não vou!

Outras questões faziam rir, ao mesmo tempo em que localizava suas fantasias em relação à viagem:

- É melhor a gente levar comida. Quem sabe a gente leva um macarrão, uns miojos, pomarola. Meu pai falou que lá a comida é muito cara. Meu pai não vai me dar dinheiro pra viajar.

- E água? Na Europa eles tem problema de falta de água. É melhor a gente levar umas garrafas com água mineral. Ou um galão...

Um dos terapeutas, numa das rajadas de perguntas lhe disse: "Escuta, a gente tá indo pra Europa, não é pra Marte." De fato, íamos de avião, não pegaríamos uma nave espacial, entretanto este modo de indagar, obrigava, menos do que a uma continência, a nomeações, principalmente para a equipe (e quem sabe isso ajudaria a oferecer uma continência efetiva), que faziam concluir que aquele ator estava sim indo pra Marte, e que 
talvez, na ousadia desta proposta, estávamos todos indo a um espaço extraterreno.

E mais questões, desta vez reproduzidas das levantadas por sua família:

- Minha tia falou pra eu arranjar uma namorada lá.

- Eu vou e não vou voltar com vocês, vou ficar viajando de mochila uns dois anos, vou arranjar um emprego. Meu pai falou pra eu arranjar um emprego e ficar por lá!

- A mulher do meu pai vai preencher o formulário pra mim. Ela não sabe preencher. Ela falou que não dá pra preencher. O que é que eles querem com tudo isso?

- Meu pai falou que não vai pagar o passaporte não. Disse que o teatro que tem que pagar. Eu não vou!

Ele ficava completamente perdido com as encomendas que a família lhe fazia: casamento, emprego, a solução de toda uma vida deveria caber nessa viagem. E ao mesmo tempo inviabilizavam um monte de coisas, atrapalhados com ele, não conseguiam preencher os formulários, não facilitavam $o$ dinheiro para o pagamento (davam-lhe cheques quando só se podia pagar em dinheiro). Chegaram a dizer, numa das poucas conversas diretas, que ele não poderia ir, que não tinha condições, já que não conseguia nem fazer o passaporte, que a equipe não devia levá-lo.

Muitas conversas foram feitas com ele. Muitas etapas de outra natureza se deram para se conseguir fazer o passaporte. Queria saber o endereço do local onde fazer. Mas não conseguia se organizar para ir. Um dia ofereci-me para acompanhá-lo. Fomos a um dos postos mas o prazo de entrega já não era mais possível. Procuramos então outro posto. No meio do caminho ele pediu para descer do carro. Disse, mais uma vez, que não 
viajaria. Convidei para um café numa padaria para uma conversa. Não quis. Saltou do carro no farol. Sozinha, parei na padaria logo à frente. Estava exausta. Frustrada. Quando estava saindo ele apareceu. Estava no ponto de ônibus, me viu sair da padaria e veio até mim. Conversamos e conseguimos combinar uma ida ao posto da Polícia Federal fazer seu passaporte no dia seguinte. Tinha que ser de ônibus, ele pedia. No dia seguinte fomos juntos fazer o passaporte. Tirou fotos. Tomamos o ônibus. Passaporte solicitado, dias depois, ele tentou buscá-lo sozinho mas não conseguiu. Fomos juntos novamente.

Sensível ao mundo, ele dizia no percurso do ônibus e na sala de espera, de um modo bastante confuso, que ele mudaria de "lado" com essa viagem, pois faria agora parte daquelas pessoas que já foram pra Europa. Ele perguntava, o que ele ia fazer quando encontrasse o "Robertinho? - um amigo que mora na rua. E assim as conversas eram desafiantes, procuravam um lugar pra aquela viagem, para que ela pudesse fazer parte da sua história; inventavam um jeito dele portar essa passagem na sua vida, suportar passá-la, vivê-la.

Com tudo isso, finalmente, os sete partiram.

Foi um encontro muito importante para todos. O grupo francês anfitrião propôs uma abertura que jamais a cia. Ueinzz experimentara. Logo na chegada este ator mais novo, perguntou para a atriz que os recebia. "Por que vocês nos trouxeram aqui?" E ela prontamente respondeu algo contundente: "Para que vocês sejam felizes!"

De fato, não era um convite num registro "produtivista" como seria mais provável, mesmo no campo das artes. Do tipo "Eu financio a viagem e vocês trabalham e oferecem uma apresentação em troca". Não. O que eles estavam propondo à cia. Ueinzz era que fossem encontrá-los; que convivessem com eles. Qualquer esforço para relatar o estatuto dos acontecimentos 
e das sensações vividas faz perceber o quanto se trata de uma experiência difícil de ser apresentada com os recursos de pensamento e linguagem de que se dispõe. O que a cia. Ueinzz vivenciou lá, foram dias de encontros sem obrigações, mas com grande compromisso. Desejo que comprometia uns aos outros estarem juntos naquelas circunstâncias, transitoriamente. Viver alguma coisa juntos, dos modos que fossem possíveis para cada um. Idiorritmia é o termo que Barthes refere a uma possível forma do viver-junto.

Nem dual, nem plural (coletivo). Algo como uma solidão interrompida de modo regrado [...] uma partilha das distâncias. [...] Aglomerados idiorrítmicos. Cada sujeito tem aí seu ritmo próprio. (2003, p.13).

[Idiorritmia] remete às formas sutis do gênero de vida: os humores, as configurações não estáveis, as passagens depressivas ou exaltadas. (2003, p.17)

Comunidades temporárias. Foi algo disso que se experimentou nesta viagem. Ritmos singulares convergindo para encontros comuns, com temporalidades a serem definidas pelas próprias singularidades. Muitas conversas, passeios, brincadeiras, danças, cantos, ensaios, sonos, apresentação de algumas cenas, observação de outras. Esses eram os lugares de acontecimento desta viagem. Numa grande mesa, para a qual todos que ali circulavam eram convidados a estar, ocorreram almoços e jantares coletivos, intensos em sua multiplicidade. Mais uma vez, cada viajante pode viver intensamente, como na maioria das viagens e temporadas de apresentação com esta cia. teatral Ueinzz, de modo intransitivo.

Nos primeiros dias, o jovem ator iniciou uma pesquisa. Queria saber sobre o estado civil da atriz principal do Thêatre du Radeau, que era também nossa anfitriã mais presente. Aos poucos, uma pergunta aqui, outra ali, ele foi tentando desenhar o tipo de relação dela com o diretor e, passados alguns dias, ele resolveu pedi-la em casamento. A partir daí, a cada encontro 
com ela, esta proposta ia ganhando forma. A cidade que estávamos tinha uma catedral medieval maravilhosa, e uma de suas propostas foi que eles se vestissem de noivos, fossem até lá e tirassem fotos, para ele mostrar a sua família que tinha casado na França. Ele dizia a ela como deveria vestir-se, com chapéu, vestido, e num outro dia, durante um passeio num brechó, comprou-lhe uma bolsa branca: presente para a noiva. E assim, sucessivamente, no passar dos dias ele foi envolvendo a todos e inventando uma das situações mais incríveis vividas nessa viagem.

Foi na véspera da partida do grupo que o casamento aconteceu.

Numa espécie de happening, uma performance, algo que ele aprendeu a sustentar e promover, favorecido em suas singularidades pelas motivações que os diretores ${ }^{23}$ sempre lhe dirigiram, e que de um modo contundente, nesta situação, ganhou uma forma extrema.

Em meio a uma festa, espécie de despedida de nossa estada por lá, um burburinho se iniciou e o casamento foi sendo montado. Vestes improvisadas na sala de figurinos, todos se preparavam, noivos, convidados... Signos iam se constelando e aos poucos um grande acontecimento se fez. $\mathrm{O}$ ator da cia. Ueinzz se casou na França., numa digressão brilhante da encomenda feita por sua família.

Ficou curado? Talvez. Certamente todos se curaram e enlouqueceram um tanto.

O teatro pode ajudar a curar-nos da crença generalizada, partilhada por muitos pacientes e também inúmeros profissionais de saúde mental, sobre sua suposta impotência ou ensimesmamento estéril, incomunicabilidade social, incapacidade criadora. Ou da ideia de que a clínica deve ficar de um lado e a cultura de outro, como se a arte não fosse ela mesma a um só tempo crítica e clínica, como se a

23 Sérgio Pena e especialmente Renato Cohen - que infelizmente faleceu, em 2005, mas deixou esse legado da performance teatral a todos da cia. teatral Ueinzz e a muitos outros artistas. 
arte não fosse já um dispositivo, como se o olhar de um diretor de teatro, a escuta de um músico, não fossem na sua exterioridade em relação ao campo clínico tradicional, e na possibilidade de assistirem a nascimentos que nosso olhar viciado abortaria, poderosamente clínica e no mais alto grau. (PELBART, 2000, p. 108).

Curado com a arte, com a clínica? Como reservar a uma ou a outra o privilégio da cura ou da loucura? Neste intervalo encontra-se a cia. Ueinzz. Casamento de desejos involuntários, instantâneos, afinidade com o que pode aproximar-se sem fusões nem vínculos prometéicos. Vizinhanças contíguas, prestes a desfazerem-se antes mesmo de concluir qualquer feito. Suspensão e ativação para viveres comuns. 
EXPERIMENTO IV

Enquete sobre o/nosso entorno (Interruptions) ${ }^{24}$

Fatos ou invenções? Em Retórica a Herênio, aparece a definição: "invenção é a descoberta de coisas verdadeiras ou verossímeis que tornem a causa provável" ([CÍCERO], 2005, p.55). Contar, não salva a experiência, não faz justiça a ela, quando muito inaugura uma outra. A narrativa não tem pretensão de retenção nem transmissão da experiência, mas de encetar outra, que se justaponha à vivida e forme com ela um heteróclito, figura privilegiada na verificação dos impasses de um tempo, de uma duração. Tomar algumas das experiências da cia. teatral Ueinzz e narrá-las é permite evidenciar matérias de risco que engessam o pensamento e/ou reificam formas asfixiantes, e que, contudo, são as mesmas que podem intensificar a crítica, afirmar a necessidade de produzir intervalos políticos - espécies de greve nas relações caducas em seus modos de fazer falar e fazer sentir -, pontos de sustentação e vitalidade fundamentais à clínica. Não obstante, este poder questionador aloja-se na própria experiência vivida, que seria inenarrável, mas que pode emergir numa fabulação decorrente de seu relato. Dizer uma experiência pressupõe poder inventá-la, descobrir nela aquilo que é passível de verossimilhança, não necessariamente factível, improvavelmente factível. Experimentar esta maquinação vertiginosa que percebe o vivo em sua incompletude e a necessidade de a todo momento engenhá-lo, reconcebê-lo.

A proximidade da artista Alejandra Riera com a cia. Ueinzz é decisiva para que esta história possa ser contada assim e não de outro modo. Assim, quer dizer, em conflito, sem

24 ÊNQUETE SÛR LE/NOTRE DEHORS (Interruptions) - título dado por Alejandra Riera às ações desenvolvidas em São Paulo, junto à cia. teatral Ueinzz, em fevereiro de 2005 e em janeiro de 2006. 
respostas, achando dúvidas. Sua estratégia agudiza nossa atenção quanto à recalcitrante necessidade de erigir verdades.

Desde 1995, [Alejandra] dedica-se a um fundo de arquivos imaginários. Trata-se do que ela chamou de Maquete-semqualidades. Nessa forma inédita de arquivo, misturam-se fotografias, legendas, textos, relatos, documentos filmados, à maneira de um 'livro em movimento', sem formato regular. São como o esboço, "o plano de uma evasão", e para todos aqueles que delas participaram, esse lugar "onde se pode contar, pensar o mundo e nós mesmos", onde se pode defrontar com "problemas não resolvidos". Por natureza leve ou precária, a maquete pode ser feita ou desfeita, e não pretende à posteridade. Pode adaptar-se ao presente, e é o presente que importa. Cada uma dessas maquetes-semqualidade abre um lugar onde muitas vozes se fazem ouvir, onde múltiplas cumplicidades se tecem e interrogam o estatuto da obra, do autor e do artista; "Mais do que nomes próprios, são lugares de que se necessita para liberar a palavra, compartilhar as responsabilidades, as vergonhas, as esperanças, as resistências". É assim que as maquetes-sem qualidade tornaram-se verdadeiros "espácios-refúgio", onde se desdobra um trabalho em curso, sempre coletivo. (CIA. TEATRAL UEINZZ, 2009.)

A escritura de cada um, a partir de uma experiência comum, é outra. Mas cada posição adotada contamina intensamente as outras, por isto a narrativa deste experimento precisa principiar neste lugar de contágio intenso. Diante destes atravessamentos, é necessário notar o ponto de partida proposto por Alejandra Riera: o de uma "situação dada: aquela que coloca em suspensão o trabalho artístico e coloca em andamento a enquete" ${ }^{25}$ (RIERA, 2006). É desde esta posição que a narrativa a seguir pretende se apresentar.

Conta de uma saída coletiva à rua. De quando estávamos, em frente ao portão de entrada do Parque da Luz. Em grupo, convidávamos pessoas para conversar conosco - parte da $2^{\mathrm{a}}$. etapa do trabalho Enquête sobre o/nosso entorno ("Enquête sur

25 Trad. livre do trecho: "pour une présentation il faille partir de cette situation donnée: celle de la mise en suspension du travail artistique et de la mise en marche de l'enquête". 
le/notre dehors" $)^{26}$ proposto por Alejandra Riera junto à cia. teatral Ueinzz.

Estávamos no portão, depois de mais uma vez termos sido expulsos de um espaço público por estarmos com uma câmera filmadora, sem autorização da prefeitura. O Parque da Luz é um lugar histórico da cidade de São Paulo, localizado em frente a uma grande estação de trem e de metrô e ao lado de um tradicional museu da cidade, de sua frequentação heteróclita sobressaem-se as imagens de precariedade: solidão, pobreza, prostituição. Junto a vendedores de pipoca, água de coco e salgadinhos, defronte ao portão, ali estávamos. Várias pessoas se disponibilizaram para nossas reportagens nas quais, sem pauta prévia, o que inicialmente se supunha era que os atores ditos loucos (em função de suas histórias de sofrimento mental) interrogariam pessoas de seu entorno, a respeito dos aspectos de suas vidas, ditos normais. Entre essas pessoas, naquele dia, uma mulher, miúda, pele negra lisíssima e brilhosa, magra, grávida, com um vestido rosa choque fosforescente, voz infantil, chamava o local de "parquinho", atendeu ao convite de um dos entrevistadores e parou para falar conosco. O ruído da rua era intenso e o grupo, exausto, parecia nervosamente excitado. Alguns rodeavam o lugar da reportagem, em círculos vertiginosos, pareciam buscar um modo de interrogar - que no limite daquela proposição era o próprio modo de relacionar-se e, ao mesmo tempo, demarcavam o espaço, como se aqueles passos nos rodeando pudessem perfurar o concreto da calçada e cravar uma linha circular que forçasse a constituição de um

26 ' $L$ ' «enquête sur le/notre dehors» a pour idée de se confronter avec une normalité inquiétante et de signifier collectivement et individuellement les espaces de friction avec elle d'un point de vue collectif et individuel. [...] Afin de décrire les éléments de l'enquête, il a été utile de la diviser en trois parties (Interruptions, Mutisme et Spéculation sur un crime) bien que le dessin général et le déploiement dans l'espace vont réunir et croiser ces différentes parties." Cf. RIERA, Alejandra. Notesdocumenta5. (Formulação provisória de escrito a ser publicado por ocasião da 12a. Documenta de Kassel), Paris, 2006. 
tablado, uma arena quem sabe, em que se pudesse adentrar, viver uma cena da vida, sob um artifício que desnaturalizasse seu horror. Afinal, somos um grupo de teatro, nos limiares da loucura, conhecemos os dois lados: o do horror e o do artifício, sem fronteiras claras... Naquela circunstância, o horror que parecia querer ser evitado, era o de uma aparentemente simples conversa, uma conversa sobre a vida normal. As perguntas iam surgindo, entrecortadas pelos barulhos do entorno e pela hesitação dos entrevistadores. "Você tem sonhos?" - alguém arriscou, repetindo uma pergunta que vinha sendo feita em várias das entrevistas. "Eu queria uma casa, um carro, um emprego, um salário..." - ela respondeu. Pronta, automática, com aquilo que parece óbvio: necessidades aprendidas por básicas, inquestionáveis para a dita "dignidade humana", mas que naquele momento soavam estranhas, não pareciam poder fazer parte do sonho daquela vida. (Talvez, àquela vida estivesse também interditado sonhar...) E a conversa foi seguindo com uma tensão evidente, sensível (à apreensão dos nervos) e seca nas palavras emitidas tanto por perguntadores quanto pela respondedora. Súbito, alguém resolve dar 1 real a ela. Um ponto alto daquela fricção em que nos encontrávamos, ponto para arrebente do encontro. Alguém de nosso grupo resolve restabelecer os lugares reconhecíveis de cada um naquela cena. Uma tentativa nobre que, mais do que a distinta caridade para com a puta, era complacente com o restante do grupo, encerrando a insuportabilidade daquela zona indiscernível em que nos encontrávamos com aquela mulher. Tudo piora. Ela pega o dinheiro e se vai, parque adentro. Após um primeiro momento de paralisia e mudez, alguém sai correndo em direção à mulher, na tentativa de encontrar uma saída diante daquele gesto que, ao mesmo tempo em que desmontara todo o esforço do dispositivo - em suspender modos pré-estabelecidos e viciados de olhar, sentir e se relacionar-, também confirmara suas preceptivas (as do dispositivo), exemplificando o estágio 
em que nos encontrávamos: impossibilitados de estar diante de alguém e não pré-supor sua vida, surdos a qualquer acrescentamento que a ela se pudesse fazer. As possibilidades de escuta encontravam-se encerradas, não havia, não há o que o outro possa dizer que não o mesmo, o já sabido por mim... Naquela cena, o conserto não foi possível. Tentativas frustradas foram desde entregar mais dinheiro à mulher, como uma paga pelo trabalho da entrevista, até um convite para um café, totalmente desconcertante, com o grupo. Só pudemos - o grupo e a própria mulher - desatarmo-nos da confusão quando, literalmente, soltamos a situação, quando a deixamos ir e pudemos ficar, separados, sem ter que salvá-la, nem ser salvos. Restou-nos essa linha de fuga: desistir do arremedo, e retomar a suspensão, pois toda forma parecia ali estar condenada e por isso, naquele momento ao menos, qualquer formatação não valia a pena. Silenciosos e cansados. Os movimentos no café prosseguiram lentos e embaraçados até nos retirarmos dali.

Foram sucessivos encontros desta natureza, encontros estranhos. Entrevistas no estacionamento do estádio do Pacaembu no momento em que terminava uma feira e homens com um caminhão-pipa lavavam a área, enquanto outros se preparavam para tomar conta dos carros estacionados, e a polícia a cavalo mantinha guarda na lateral, e uma mulher moradora de rua, com uma sacola de roupas, queria agendar uma entrevista para um dia em que estivesse mais arrumada. Num outro dia na esquina de uma rua, depois de entrevistas no ponto de ônibus em frente a praça Buenos Aires, entrevistamos três meninas no intervalo de lavar vidros dos carros e também um vendedor de guarda-chuvas. Na praça da Sé caiu um temporal e as entrevistas aconteceram embaixo de uma banca de revistas, sob um olhar de reprovação da dona, diante das profecias de um visionário. Numa outra ocasião, fizemos uma visita, guiada por um engenheiro, através das imensas obras de reforma e restauro do 
centro cultural Maria Antonia que, outrora, fora posto de triagem da polícia para suspeitos de oposição política à ditadura militar. E ainda estivemos em entrevistas na passarela do terminal rodoviário praça das Bandeiras; com dois jardineiros e com estudantes nos corredores do hospital Santa Casa de Misericórdia; num ponto de táxi, com um cego, técnico em radiologia; em frente a Assembléia Legislativa com o vendedor de doces e a policial que fazia a segurança; com a cozinheira e alguns terapeutas do hospital-dia A Casa; com poetas e escritores no parque Trianon que discutiam com ferocidade supostos subjugamentos de um ou outro a uma instituição de tratamento comum aos dois.

Cada uma destas saídas era decidida em reuniões com todo o grupo de atores-entrevistadores, cuja configuração flutuava dia-a-dia - um dia eram 15 , noutro 4 , noutro 9 - e as hipóteses para esta variação vão desde a organização individual cotidiana, o cansaço pelos medicamentos, a dificuldade de engajamento num compromisso diário e extenso, até a própria intensidade da proposta, e mesmo sua condução imprevisível e conflituosa. Nas reuniões, chamadas de ateliês, além de decidir os lugares do entorno onde ocorreriam as enquetes, o grupo tentava estabelecer estratégias para realizá-las. As entrevistas já feitas eram assistidas e discutidas, o que, em geral, criava muito mal-estar: ver-se no vídeo, numa situação aberta, sem contornos verbais (as perguntas eram todas improvisadas), nem mesmo de imagem (ora a câmera filmava diretamente a entrevista, ora filmava seu entorno deixando a voz em primeiro plano, mas a imagem dos entrevistados e entrevistadores fora de cena). Houve um momento em que alguém se vestiu com luvas de jornal; outro em que um poema foi lido para pessoas na calçada; outro ainda em que uma das atrizes improvisou um monólogo no ponto de ônibus. As perturbações e os incômodos eram matéria persistente e aos poucos elas passaram a ser suportáveis e a 
oferecer certos tons para o trabalho a seguir. O grupo de atores devotava-se generosamente às propostas, reclamavam entendimento, esperavam por ele e não o alcançavam propriamente, e ainda assim, lançavam-se à continuidade. Mais entrevistas, depoimentos individuais... Era incontestável que com a proposta da Enquete sobre o/nosso entorno buscava-se alguma coisa que o grupo não sabia o que era ao certo, mas que queria muito oferecer, experimentar, e sem saber o fez, uma vez que nenhum estrondo - a não ser os dos raios na praça - se apresentou. Apenas silêncio, dúvida, inquietação, esgotamento, talvez. Um projeto que não servia a nada, sem utilidade artística, social, cultural ou outra qualquer. Algo da ordem da política das relações, que insistia em suspender automatismos, sem propor nenhuma novidade espetacular, apenas travessias... Duras. Tão duras que é possível suspeitar que acabassem por se espetacularizar nesta dureza, nesta secura... Não que não houvesse um quantum relevante de afetos, mas sem saber sua rota, perdidos, eles pareciam saltar e cair. Queda. Diferente de apresentar-se num teatro da cidade, num festival, expor-se numa galeria, num museu: nestas situações, alguém vai com propósitos, alguém se apresenta sob propósitos... Mas aqui, quando o propósito é desmontar propósitos, resta o abismo. Abismados ficaram todos.

Menos do que uma demonstração representativa ou argumentativa, a narrativa das experiências com Enquete sobre o/nosso Entorno poderia ser tomada por uma alegoria, no sentido em que ela exprime, discorre realidades intensificando pontos de conflito, mapeando os signos que revelam sua sintomatologia, bem como sua vitalidade. Trata-se de um habitat que põe em questão sobretudo aquilo que se estabelece sobre suas principais rubricas - seja arte, seja obra - e quem sabe até desmanchá-las, numa operação que não requer novidades mas 
persistências e reincidências, e por isto pode inscrever-se no rastro daquilo que é nocionado como o contemporâneo.

[...] o termo 'contemporâneo' designa alguma coisa, um horizonte de modos de fazer e apresentar trabalhos que se inscrevem como elaboração interpretativa, como anamnese do moderno - o contrário portanto, da simples reatualização de formas, processos, temas e materiais. (FAVARETTO, 2006, p. 255).

Uma vez contemporânea, a proposição da Enquete tem, talvez, como uma de suas funções de relevância, pôr em evidência certas marcas desse tempo e impedir que sejam atravessadas como óbvias ou banais, ou que sejam atropeladas em seus sentidos, ou ainda neutralizadas ou espetacularizadas em seu horror. Faz sentido inscrever as ações de Enquete sobre o/nosso entorno no rol daquelas que se distanciam de outras tantas, no campo das artes - profusão de obras e discursos contemporâneos -, que estetizam as situações do mundo reiterando formas de associar a arte e a política a partir de clichês ambientais e ideias decalcadas e em plena vigência, que evitam o trabalho necessário de crítica aos efeitos de nosso regime político, e acabam os reforçando. Fazer diferença em relação a este panorama, devotaria às artes o papel de questionar-se sobre seus modos de produção e relação com as categorias preestabelecidas do mercado e dos lugares de apresentação e intervenção. Para tanto, viria em seu auxílio uma pauta de questões: "Como, hoje, produzir obras que não pressuponham suas condições/sistemas de recepção? Como preparar com cuidado momentos/espaços de latência, de disrupção da ordem e da velocidade esperados (indiferença, indecidibilidade?)" (DAVID, 2005). A mastigação (senão, ruminação) feita pela massa de produções contemporâneas em artes, pasteuriza grande parte dos elementos que efetua diferenças numa cultura. E o faz num procedimento ambíguo que, por um lado, destaca estes elementos em sua diversidade, e em seguida os decalca, aprontados para o consumo, na forma de 
imagens publicitárias, hipertextos, interatividade, etc. A exemplo disso, a exigência comunitarista, o coletivismo imposto pelas ditaduras da modernização restauradora, acaba por investir em vinculações compulsórias, que desdobram-se em regimes de tolerância evidente em slogans do tipo "respeitar as diferenças", "somos todos iguais", "o mundo é para todos" etc. Problematizar este circuito implicaria na questão contemporânea do desobramento, uma arte para não fazer obra.

Mais aquém ou mais além da obra, isto que se retira da obra isto que já não tem nada a ver com a produção, nem com o consumo, senão que tropeça com a interrupção, a fragmentação, a suspensão. A comunidade se faz da interrupção das singularidades, ou da suspensão que são os seres singulares. Ela não é sua obra, e não os tem como suas obras, assim como tampouco a comunicação é uma obra, nem sequer uma operação dos seres singulares: porque ela é simplesmente seu ser - seu ser suspenso sobre seu limite. ${ }^{27}$ (NANCY, 2001, p. 61-2)

Esse desfazimento da obra exige cautela nas possíveis constelações de seu exercício e conhecimento. Com efeito, a fabulação da experiência de Enquete sobre o/nosso entorno opera num registro de multiplicidades, circunstâncias distintas, não intercambiáveis que não podem imbricar-se numa argumentação compositiva num alinhamento direto de categorias das artes com outras da clínica. Neste domínio frágil, apenas algumas sutis migrações podem se fazer. No entanto, em função das distâncias e até mesmo da alocação destas instâncias em universos distintos, incidem algumas operações de contraste, na busca por aproximações que forjem sentidos que podem

27 Trad. livre do trecho: "La comunidad tiene lugar necesariamente en lo que Blanchot denominó el desobramiento. Más acá o más allá de la obra, eso que se retira de la obra, eso que ya no tiene nada que ver ni con la producción, ni con la consumación, sino que tropieza con la interrupción, la fraggmentación, el suspenso. La comunidad está hecha de la interrupción de las singularidades, o del suspenso que son los seres singulares. Ella no es su obra, y no los tiene como sus obras, así como tampoco la comunicación es uma obra, ni siquiera una operación de los seres singulares: porque ella es simplemente su ser - su ser suspendido sobre su límite. (NANCY, 2001, p.61-2) 
inicialmente incorrer em discrepâncias. De modo afirmativo, resta estabelecer alguns ecos e ressonâncias.

Tramar um pensamento comum é uma saída possível, um modo de pensar que seja avesso à teleologia facilmente reconhecível no voluntarismo que age como um veneno para as ações de nosso tempo, inclusive na clínica. Essa impetuosidade humanista e personalista advém da necessidade em reagir; a ideia de uma meta traçada antes de estar diante de alguém. A tentação em empreitar a vida do outro, em fazer dela um grande projeto faz o pensamento restringir-se às finalidades dos gestos depois de terem sido feitos, ignorando que quaisquer conclusões que levem a certos gestos em relação a outrem, mesmo diante dele, são provisórias e insuficientes, quando não equivocadas.

Não fazer nada. Simplesmente estar com alguém e estranhá-lo. É um grande desafio para os que trabalham na clínica: atuar no deslizamento das superfícies. Não se trata de revelar obscuridades, tampouco subtextos. O que acontece é o que acontece sem que fosse preciso acontecer. Nem opiniões, nem causas lógicas, Deus ou qualquer forma de absoluto que pretenda representar as coisas, impedindo-as que se apresentem por elas mesmas. Contrário a um enraizamento, o trabalho clínico estaria assim, a serviço de um alastramento.

Esse modus operandi - escolher o que parece melhor entre vários exemplos que se lhe apresentam -, que Cícero declara ter adotado ao escrever sua arte retórica, explicita-se ao fim do exórdio como atitude a ser adotada na vida, diante de qualquer matéria de conhecimento. A atitude mental sempre aberta à dúvida, bem ao gosto da filosofia acadêmica seguida por Cícero, faz com que pesem as vantagens e desvantagens de cada possibilidade, de modo que nada seja escolhido ou preterido sem a devida ponderação. Assim, servir-se de um único modelo de manual para em tudo imitálo seria agir irrefletida e obstinadamente, atitudes que ele rejeita como contrárias ao conhecimento.(FARIA; SEABRA, 2005, p. 26) 


\section{EXPERIMENTO V}

\section{Longe, quando a estranheza ameaça tornar-se familiar}

A possibilidade de "se passar por normal" é uma chance muito atraente para quem atravessa toda uma vida sob o estigma do louco, do deficiente, do anormal. Se há discursos que proclamam a inclusão, e arremedam situações de equidade, forjando homogeneizações quase sempre sustentadas pela tolerância e pela caridade, há outros que tentam afirmar esta condição marginal, acreditando nela como um signo de questionamento das formas hegemônicas, buscando alargar o mundo e fazer caber nele outras formas de existir - o que por um lado abandona a perspectiva normatizadora, por outro, empreende muitas vezes o anormal como estandarte, e ignora ou desqualifica um aspecto importante, concernente à dor daquele que não pode acessar os códigos vigentes, cujos protocolos, por mais estúpidos e fabricantes desta sua condição, são por ele desejados: "tive apenas a experiência de não ser contemporâneo de nenhuma experiência." (PESSANHA, 2009, p. 44). É um impasse para aqueles que se dispõe na posição de cuidado: o sofrimento precisa ser reconhecido como marca do vivo e possibilidade de travessia, entretanto ele precisa, por vezes, anestesiar-se, imiscuir-se naquilo que foi socialmente instituído e que predomina.

Foram duas viagens internacionais de toda a cia. teatral Ueinzz. Ir para a Europa: signo consagrado de reconhecimento social. Estultice. Todavia, elemento suficiente para o embarque numa glamorização deslumbrada, primeiro ponto de defecção a ser enfrentado.

Tudo o que arraiga os homens por meio de valores, sentimentos, em um tempo, uma história, uma linguagem, é o princípio de alienação que constitui o homem como 
privilegiado que é (francês, o precioso sangue francês), que o encerra no contentamento de sua realidade e que o conduz a propô-la como exemplo e a impô-la como afirmação conquistadora. Marx disse com sereno vigor: o fim da alienação só começa se o homem aceita sair de si mesmo (de tudo o que o institui como interioridade): sair da religião, da família, do Estado. O chamamento ao exterior - um exterior que não seja nem outro mundo, nem um mundo passado -, não há outro movimento para opor-se a todas as formas de patriotismo, quaisquer que sejam. (BLANCHOT, 2006, p.107)

Viagens de tal magnitude, nunca antes nos foram possíveis e, entretanto, nos últimos anos, elas surgiram em sucessão. Paradoxais já no convite: companhia teatral brasileira, de atores com histórias em serviços de psiquiatria e de saúde mental, convidada a participar, primeiro, numa cidade da Alemanha, num evento de arte contemporânea, conhecido como dos maiores da atualidade, a Documenta de Kassel; depois, num festival de teatro, Baltic Circle International Theatre Festival, célebre num território completamente desconhecido, a cidade de Helsinque, na Finlândia.

As distâncias numa viagem, favorecem sensações de medo e de euforia, às vezes simultaneamente, com isto, a preparação exige manejos de ansiedades e fantasias, que tocam em regiões de realização - algumas mais estereotipadas, outras mais vitais -, e de aniquilamento. Com a devoção de muitos cuidados, o deslocamento de uma quantidade de gentes, separadas de seus ninhos enclausuradores, ou de seus abandonos habituais, é uma empreitada de alto risco para o pequeno grupo de terapeutas que, na assimetria deste coletivo, tem o compromisso de cuidar para que a experiência possa vingar. Cuidar, nesta ambiência, inclui ações concretas e convivências fantasmáticas: ninguém pode morrer, ninguém pode sumir sem sinalizar, ninguém pode se matar, ninguém pode ser preso, ninguém pode ferir nem ferir-se, ninguém pode perder-se, ninguém pode ser esquecido... e entretanto, tudo isto já nos aconteceu, diretamente, e em nossos arredores. E aquilo que 
seriam signos de desestabilização mortífera para o conjunto é fagocitado, numa espécie de assimilação esquizóide, que engole pra fora. Sob o desejo de parecer normal, viajantes civilizados, preparados e adequados, somos sempre estranhos, uns aos outros, inclusive, e assim seguimos estas viagens, sob direções transitórias, no mais, errantes. Pra que mundos nos deram passagens?

Ent-Stopfung $^{28}$. Abria-se uma cartolina segurada nas pontas por uma das atrizes e, minutos afora, em silêncio, ela vai sendo filmada. A suspensão do tempo e do espaço aos poucos dispara incômodos nos que estão em volta: risos, impaciência, desistência. No estacionamento de uma fábrica de automóveis ou no jardim de entrada de uma comuna, cada um vai encontrando seu lugar de encostar, às vezes levantam-se, andam por perto e mudam de encosto.

Dos ateliês em vídeo que vínhamos realizando há 2 anos, sob a coordenação de Alejandra Riera com o dispositivo Enquete sobre o/nosso entorno ${ }^{29}$, desdobrou-se este convite, motivo de grande entusiasmo da cia. Ueinzz, para apresentá-lo numa mostra que reunia processos de artistas de todo o mundo, num evento alemão que, do ponto de vista da visibilidade e globalização de seus efeitos, tinha proporções econômicas, culturais e sociais vultuosas. Diante das dimensões e do alcance conhecidos desta mostra de arte contemporânea, o que se

28 UNTERSUCHUNG ÜBER DAS/UNSER AUßEN(Ent-Stopfung) "Enquete sobre o/nosso entorno (Desobstrução)", título usado no cartaz que abria cada uma das filmagens feitas em Kassel na Alemanha, em julho de 2007.

29 Experiência apresentada também no experimento IV, que "ativou com os atores da companhia um dispositivo de enquete e registro muito preciso, embora aberto. Consistia em uma saída coletiva por dia, para algum ponto da cidade sugerido pelos atores, onde cada um abordava alguém de sua escolha, pedestre, vendedor, estudante, policial, anônimo, morador de rua, e lhe lançava à queima roupa as perguntas que lhe viessem à mente. Numa situação insólita, onde o entrevistado ignorava tudo do entrevistador, mas por vezes percebia uma estranheza, as regras de uma entrevista jornalística eram reviradas, e tudo começava a girar em falso." (CIA. TEATRAL UEINZZ, 2009.) 
anunciava para esta viagem era simultaneamente uma estrutura material garantida e uma espécie de trituração das sensibilidades. Isto fez com que a decisão para aceitar o convite fosse atrelada a uma proposta de reativação do dispositivo da Enquete, dando continuidade ao processo realizado em São Paulo, desta vez, no entorno de Kassel. Ponto problemático: como chamar de o/nosso entorno, o estrangeiro? Qual a capacidade de não ser turista num terreno desconhecido em que não se sabe o ônibus a ser tomado, os modos de demandar as coisas cotidianas, a direção das ruas, o que comer, a temperatura, como vestir-se?

Assim aconteceu, assim devia acontecer: uma viagem que se foi e que estará sempre. No inverno de 2007, a cia. teatral Ueinzz fez uma viagem para um verão, uma viagem que significou um grande deslocamento, evidentemente, não pela distância geográfica percorrida, mas pelo que esta distância material pôde provocar de encurtamento, aproximação e intimidade.

Reunidos na sala de espera do aeroporto, uma pasta cinza de plástico poliondas chamava cada vez mais a atenção, um dos atores a carregava, levando nela uma única folha de papel canson A2 com uma pintura feita por ele: uma série de pinceladas que compunham, numa espécie de ondas em vibração, a imagem de um corpo musculoso com peitos salientes, (como os de uma púbere fêmea), e uma cabeça de felino humanizada, com uma espécie de juba esvoaçante. A pasta, assim ele determinou, tinha que ser carregada como bagagem de mão, e seu destino era mostrar esta pintura a uma tia que mora na Suíça e que, eventualmente, poderia passar pela cidade em que estaríamos. De um modo estranho, aquilo revelava um entendimento colonizado: a ideia de que ir à Europa supunha que todos os habitantes daquele continente passariam por nós. O continente distante tomado como signo absoluto, bloco único, território total, inimaginável em qualquer 
configuração geográfica que não a dos mapas de papel, onde ela está lá em cima, algo como um grande estádio poderoso e imponente, onde todos estão o tempo todo reunidos. A tia da suíça ia estar na cidade do interior da Alemanha para ver o papel pintado pelo ator: sua viagem. A cada pouco, na demora do embarque, alguém solicitava ver o que tinha dentro da pasta, como que pedindo uma explicação para aquele desajeitado volume que era carregado, encostado, esquecido, mas que aos poucos passou a ser cuidado coletivamente, como uma bagagem que pertencia a todos, de um modo estorvante. Cada pedido por abri-la vinha da presunção de que a pasta estava evidentemente indo para algum lugar longínquo e por isto devia conter algo que valia a pena ser levado com tanto zelo. Ao ser aberta, a surpresa não surpreendia, não era o conteúdo da pasta que valia tanto, era então o quê? A empreitada parecia ser extensa, lançaríamo-nos por uma vasta região do estrangeiro: Europa, França, Suíça, Alemanha, Europa, Documenta, Aeroporto de Frankfurt, Kassel...; tudo eram signos de distância, sinais de que estávamos partindo pra longe.

De saída, o grupo se compôs pela equipe de coordenação e os demais atores num total de 15 viajantes. Chegando lá, a recepção foi feita por 3 motoristas-cicerones-intérpretesprodutores de estadia, enviados pela Documenta. Em seguida, no hotel, somou-se ao grupo Alejandra Riera, responsável pelo processo exposto na Documenta, bem como pela montagem do dispositivo e pelo convite para a cia. teatral, e mais com a produtora deste trabalho coletivo, ambas vindas da França. Até aí, eram 20, mas conforme a companhia passava pelos eventos programados ou desprogramados com a sua presença, outras tantas pessoas juntavam-se a ela, por todo o percurso, por parte dele, em pontos dele: monitores e simpatizantes da Documenta, visitantes, conhecidos, desconhecidos, ilustres e perdidos. As travessias eram convites e rechaços: alguns se atraiam fortemente com as passagem do grupo, outros se esquivavam, 
esforçando-se pela indiferença. O que parecia predominante era uma espécie de anestesia, uma indiferença blindada que transparecia nos transeuntes, prováveis moradores daquela cidade que, a cada cinco anos, desde 1958, transforma-se numa espécie de disneyland da arte contemporânea. Disto resultava esta frieza que explicava de antemão toda estrangeridade na insígnia desta exposição-espetáculo, cuja ultrapassagem é datada resguardando o retorno à normalidade de suas rotinas.

Esta referência aos trânsitos da cia. teatral pela cidade de Kassel, de início, poderia convocar imagens de um bloco homogêneo de loucos em marcha pelas ruas e lugares designados por alguma instância soberana, entretanto, ela foi constituída por uma série de movimentos e deslocamentos bastante singulares e sutis, até mesmo imperceptíveis: um vai-evem de corpos e rostos estranhos, rondas sem propósitos, um conjunto pequeno que se adensava subitamente e imediatamente se desfazia, falas desconexas e intensas, sensações de esquecimento: de alguém, de alguma coisa, de algum lugar, e também barulhos, pequenos tumultos, gritos eventuais, choros, brigas na esquina, comidas sendo devoradas, corpos em torção. Elementos de presença singular, de uma presença estranhamente comum

Adentrar uma cidade estrangeira com o dispositivo da Enquete fez este conjunto de pessoas vagar e deslocar-se por muitos lugares, e a sensação que retornava era a de que nada acontecera e nada aconteceria. Uma comuna, o centro comercial da cidade, uma fábrica de automóveis, um antigo prédio utilizado pela Gestapo. E todos estavam exaustos, esgotados de tudo e de nada. Cada decisão era tomada depois de muitas fricções, atritos com todo o entorno daquela experiência. E as saídas eram hesitantes, idas e voltas: onde ir primeiro? quem quer ir no segundo lugar mas não no primeiro? quem não sabe se irá para algum? quem aparece sem saber se vai? quem vai sem saber se foi nem para onde? São relatos imateriais, sobre 
matérias que não têm palavras para serem ditas. As vivências pareciam fazer-se de alguma matéria, mas as palavras, ao não alcançá-las, coloca em questão sua existência. E esta impossibilidade de comunicar os acontecimentos desta comunidade dos sem comunidade (Bataille), ou seja, esta experiência que não pode ser enunciada, que não tem como ser dita e que portanto está em risco de não existir, é consonante com sua própria efemeridade, aquilo que impede que ela se institua, ou ainda, que ela se institucionalize. Estar fora da linguagem, fora da língua.

A linguagem não é informativa nem comunicativa, não é comunicação de informação, mas - o que é bastante diferente - transmissão de palavras de ordem, seja de um enunciado a um outro, seja no interior de cada enunciado, uma vez que um enunciado realiza um ato e que o ato se realiza no enunciado. (DELEUZE; GUATTARI, 1995b., p.17)

A língua, enquanto instrumento para a construção do discurso do poder, ditado das palavras de ordem que enunciam o que deve ser feito, esta língua foi um elemento de desterritorialização nesta viagem. Os primeiros deslocamentos dos amontoados da cia. teatral com aquele que foi designado para ser seu "tradutor" prenunciavam o desentendimento: cada fala era imediatamente adequada às circunstâncias, conforme a avaliação e previsão do tradutor, o que resultava ora em indiferença ao que se dizia, ora em arranjos estranhos e inconvenientes, ora em castrações explícitas. E isto era perceptível, e realizava parte da previsão de que as sensibilidades seriam trituradas. Silenciosamente alguma coisa emudecia em nós. Com o passar dos dias tivemos que afastar esta tradução despótica, e inventar novos dispositivos que funcionassem como espécies de transposições, tal qual a brincadeira do telefone sem fio: alguém que sabia alemão e francês, traduzia para alguém que soubesse francês e espanhol, que traduzia para alguém que soubesse espanhol e português que traduzia para todo mundo; alguém que soubesse alemão e inglês, 
traduzia para alguém que soubesse inglês e português de portugal que traduzia para todo mundo que adaptava ao português do Brasil. Paradoxalmente, esta caótica deixava a todos mais seguros, a palavra parecia circular as sensações imprescindíveis e, muito provavelmente, indizíveis daquela experiência estrangeira. Ainda assim, outros movimentos ocorriam: alguém que não soubesse alemão falava em português e em portunhol e em inglês, assim como que soltando todas as palavras estrangeiras, ou supostamente estrangeiras de que dispunha e conseguia permanecer em algo próximo de uma conversa, com alguém que só falava alemão.

Estes elementos, que parecem colaterais a uma eventual função que a viagem poderia ou deveria ter, explicitam de modo contundente as constelações atravessadas que constituíram a matéria enunciadora desta cidade inventada. A língua enrolada, a tradução ziguezagueante e, contudo, esta comunidade temporária e flutuante, circulando por aquela cidade dura, exerceu-lhe uma atração. A comunicação se fez pelo próprio contágio.

Sobrepõem-se aqui algumas questões, que indagam sobre qual fala e qual língua comunica e efetua encontros: o desajuste das falas dos atores ou o suprajuste do tradutor? Qual interpretação valida uma situação? Interdições recíprocas não constelam uma experiência comum, uma vez que cada um insiste em colocar o outro no lugar do mesmo. Aquele que quer falar em nome do outro, que se arroga o direito de consertar a sua voz, solícito em ajudá-lo, é também solícito em cerceá-lo. Qual é a melhor tradução: a de quem conhece bem a pragmática da língua, a de quem conhece bem o gênero do discurso, a de quem se afeta com a presença do gaguejante? E do mesmo modo, quem segura o microfone para as entrevistas: o técnico especialista ou o amador-disponível que pode tornar-se um afeto especializado para a situação? E com isto tudo, o que aconteceu? Nada. Entre o muito importante e o irrelevante, antes de poder 
discriminar-se o sentido suspendeu-se, e saltou para outras viagens, descontínuas e delas decorrentes.

Entre tantas línguas e tanta mudez, a pasta poliondas ficou no hotel, sozinha no quarto. A tia não veio, mas o dono do desenho sumiu. Por horas, madrugada adentro, foram revolvidas, sem êxito, todas as possibilidades para encontrá-lo. Passado um tempo, ele ressurgiu, abatido por uma incursão frustrada em seus anseios de vertigem e transgressão, triunfante, sem o saber, na exploração para nada de uma superfície, cuja dificuldade de encontrar suas razões, advinha do fato de que não as haviam: a viagem não tinha uma utilidade e isso era inquietantemente bom. Em meio a alguns frágeis acontecimentos, cujos gestos lutavam por renunciar a prescrições ideais, constituíam-se campos com pulsações heterogêneas, pontos vivos em ajuntamento, sem ordenações prévias, sem necessidades a serem satisfeitas, necessariamente passando pelo desejo de estar-junto que, liberando as decisões da vida de restringirem-se a um eu prometedor de inteirezas e completude, prescreve compromissos que não precisam ser cumpridos e que no entanto o são. Algo relacionado a uma imanentização que coloca todos à espreita para, conforme o comentário de alguém numa das rodas de conversa do dispositivo da Enquete, "estar à altura do espaço de adentramento oferecido".

Finn. Para os finlandeses, Finneganns Ueinzz rendeu muitos aplausos. Kiitös. Daquela estranha língua, era a única palavra que se conseguia pronunciar. Palavra de agradecimento. Obrigado.

Apreensiva, com pouco dinheiro, noção precária sobre como agasalhar-se, como comunicar-se, como locomover-se num outro país, que de tão estrangeiro podia facilmente 
confundir-se com outro planeta, entre várias intempéries, a trupe prosseguiu.

Desde 1997, a história da cia. teatral Ueinzz é assinalada por marcas acentuadas com a prática do teatro - seu mote principal -, entretanto, uma linha parece ter sido ultrapassada nesta viagem. Durante sua participação no Baltic Circle International Theatre Festival, menos que viajantes, os integrantes da cia. Ueinzz foram atores, o ofício teatral assumiu o centro da cena. Em terras longínquas, a matéria mais substanciosa do grupo foi ovacionada, signo de reconhecimento das apresentações, da pesquisa e da singularidade artística do projeto. Num jornal de Helsinque, a chamada: "O grupo brasileiro nos lembra como é importante acreditar no mundo.”, indiciava uma legitimação imprevista:

Finnegans Ueinzz é uma performance na qual a platéia se entrega. Quando você vai embora, você se sente faminto, e pronto para sonhar. No início, a expressão facial dos atores está virada por dentro, como se seus pensamentos estivessem parcialmente náufragos, travados, presos. Contudo, sua presença não está afinada de um modo aflitivo ou angustiado, mas com uma ternura notável e de um modo digno. Essa impressão faz você ficar mais atento: você vê expressões que não querem expressar algo pré-determinado, vê rostos que não querem ser vistos de modo usual, que não querem falar em uma linguagem pré-fabricada. [...] Finnegans Ueinzz traz para o palco cenas, sequências, visões, canções, suspiros e sonhos e toca o público finlandês como a uma harpa. Ela molda um rizoma de estilos teatrais, um organismo vivo em constante mudança mas ensaiado, onírico, mas em vigília. O grupo escava uma arqueologia da mente e da linguagem ao combinar com sua própria lógica o singular, cenas borbulhantes e não-conectáveis a citações de textos clássicos. De repente você está nadando nas profundezas do oceano onde um homen mergulha com uma sacola de papel em sua cabeça, tão rápido como você então começa a falar em uma língua disparatada, e então está pedindo sua última refeição antes de morrer, e então tentando impressionar de modo comicamente frenético. [...] $\mathrm{O}$ espaço muda de acordo com as posições e ângulos que as pessoas estabelecem umas com as outras, o mundo é criado nessas relações, e nessas relações morre. A massa sonora funciona como uma encenação densa. A performance não deslumbra, mas foca de um modo indistinto a medida em que ao público é permitido construir suas próprias histórias, para iluminar seus próprios pontos de vista. A cena mais 
impressionante é a final, que amarra todos os fios soltos. Uma senhora, de face pétrea, conta que foi proibida de falar. Ela falou e foi punida. Mesmo assim ela falou. A única dimensão social a ser seriamente considerada culmina na seguinte questão para o teatro atual: Quem pode repensar o palco, quem pode também fazer com que esse palco seja da platéia? A performance da Companhia Teatral Ueinzz talvez não seja a única resposta, mas certamente é uma de suas sementes mais significativas. Em Finnegans Ueinzz o mundo não dorme em um tempo passado. ${ }^{30}$ (SÄKÖ, 2009).

A exterioridade desta audiência parecia colocar a cia. Ueinzz numa condição favorável para professar seu ofício. Profissional. Nem mãe, nem tia, nem primo, nem vó. Os finlandeses eram os espectadores extra-familiares que desterritorializavam completamente as expectativas e instalavam o grupo num outro terreno, região disforme que se engendrava neste próprio deslocamento. Congratulados pela justa coisa a que se dedica fazer, aquilo que motiva o estar-junto da cia. e que reúne suas potências e possibilidades foi surpreendentemente admirado, efetuando uma validação inesperada, embora pertinente à atmosfera dos esforços há muito empenhados. Distante da ambiência doméstica, as apresentações - que foram duas - ocorreram de modo muito profissional e, espantosamente, conseguiram estabelecer uma conexão com um público numa língua com signos e origens radicalmente estrangeiros aos da trupe. Não há como negligenciar que tal eficácia deveu-se também a uma inteligência da direção artística da cia., na utilização de recursos de tradução (legendas e tradução simultânea) sintonizados com a temática do projeto "Finneganns Ueinzz", realizado com interferências sacadas da obra de James Joyce, com cenas relacionadas à invenção de línguas, a traduções que não se traduzem, a traduções da língua com a própria língua. Isto parece ter forjado uma espécie de comunicação do incomunicável.

30 Artigo traduzido para o inglês por Akseli Virtanen e para o português por Elisa Band, com revisão de John Laudenberger. 
Provavelmente, por tratar-se de um festival de teatro (em nada relacionado a equipamentos e serviços psiquiátricos e/ ou de saúde mental), a recepção da característica diferencial dos atores, a saber, suas vivências com o sofrimento mental grave, foi feita de maneira muito esquisita e ambígua. Isso ficou explícito, por exemplo, no modo como os responsáveis pelo evento organizaram o debate com o público ao final de uma das apresentações, para o qual, sintomaticamente, foram convidadas duas arte-terapeutas, propondo-se com isso uma moldura restritiva para o início da conversa, tendenciosa às experiências particulares e individuais dos integrantes do grupo, tentando tragar as relações ali nascentes para um lugar pré-fixado. No entanto, este enquadramento foi logo subvertido pelos atores, com comentários do tipo: “- vocês estão querendo saber da nossa esquizofrenia?”, “- não, não, vocês estão enganados... aqui a gente não é paciente, aqui a gente é ator!", ou ainda: "esse negócio de arte e loucura não existe, arte é arte e loucura é loucura, o que a gente tá fazendo aqui é teatro." Essa desmontagem foi acolhida de um modo interessado pelos que estavam ali presentes, e o que parecia prestes a ser engessado, revelou-se uma espécie de mau jeito, uma configuração desastrada aberta a tomar outro destino. Num outro momento, durante uma entrevista para a rádio finlandesa, esse desajuste se repetiu, e quando indagados sobre as origens do grupo - evidentemente buscando uma maneira de a relação com o hospital psiquiátrico ser mencionada -, um dos atores assim pronunciou-se: "nós estávamos numa praia pescando, aí veio o Peter e então a gente foi pegando umas pessoas que queriam virar pessoas... Depois, a gente entrou na nossa nave e veio parar aqui. E vocês? Vocês sabem pra onde tá indo a nave de vocês?"

No circuito dos fazeres teatrais, mais ou menos ajustadas as relações foram se realizando numa faixa de contentamento, contrastante a ela uma outra faixa se impunha: a do aporte cotidiano. No vento gelado, despidos os figurinos, o 
dia-a-dia da viagem da companhia recebeu um suporte técnico restrito às condições previstas por ambas as partes, pautadas em conhecimentos apenas presumidos. De fato, nos contatos travados através de redes virtuais e de telefonia, nenhum sabia efetivamente do outro, a ponto de poder melhor supor expectativas e necessidades, de um certo modo, reciprocamente, era um tiro no escuro que se dava, uma aposta baseada na imaginação. Tal é o descabimento de um cia. teatral Ueinzz: qualquer, atípica, singular, na relação com um país como a Finlândia: reto, limpo, certo. Funcionalismo finlandês: eis como eles mesmos denominam seu principal "ismo" artístico. Naquele país, todos tem telefones móveis e os telefones públicos foram suprimidos. Nessa bem sucedida sociedade tecnológica, para que haja encontro, o tédio da eficiência precisou ser deslocado, e para isto contou-se com a ajuda da loucura, rumo a um lugar que ainda inexistente, e que não se sabe se vai existir. "Enfastiado de ter razão, de fazer o que tem sucesso, da eficiência dos procedimentos, tentar outra coisa." (VALÉRY, 1997, p. 69)

As condições de estadia e de deslocamento ficaram, assim, absolutamente aquém do imprescindível. Aos integrantes - alguns mais debilitados pela idade, outros por comprometimentos neurológicos, ou ainda pelo uso de muitos medicamentos, ou por desorganizações espaço-temporais -, os recursos disponibilizados não correspondiam a suas necessidades: o alojamento era distante, não havia comida próxima, os deslocamentos eram em sua grande maioria a pé ou de transporte público, com muitas baldeações, e a agenda de compromissos era extensa. A equipe de coordenadores teve, com isso, muita dificuldade em oferecer ao grupo as condições necessárias para enfrentar as adversidades, e protegê-lo minimamente de uma desagregação - sempre iminente, dada a coexistência essencial de vitalidade e mortalidade, que determina a frágil linha em que o grupo se mantém. 
Por que a linha de fuga é uma guerra na qual há tanto risco de se sair desfeito, destruído depois de se ter destruído tudo o que se podia? Eis precisamente o perigo: que a linha de fuga atravesse o muro, que ela saia dos buracos negros, mas que, ao invés de se conectar com outras linhas e aumentar suas valências a cada vez, ela se transforme em destruição, abolição pura e simples, paixão de abolição.(DELEUZE; GUATARRI, 1996, p.112.)

Brigas, ferimentos, ameaças, pequenos sumiços, demandas autoritárias e desobediências arriscadas impediram revezamentos e vacúolos de distância e solidão que em outras logísticas foram mais possíveis. Fora dos palcos, toda essa viagem foi bastante tumultuada - um tanto mais que as outras com pequenas tragédias que ora pareciam tudo quebrar, sem chance de restauração, adentrando linhas de microfascismos nas relações, e ora eram motivo de risos, regozijo e alívio por vislumbrar a movência de coisas aparentemente imutáveis por meios insuspeitados. Esta foi sua força.

Mais uma vez, a tarefa de atravessar as máquinas detectoras de coisas escusas se impunha. O que se estaria escondendo? Todos os que passam são terroristas em potencial. Do grupo, algumas pessoas foram obrigadas a acompanhar os vigias para assistir a abertura de suas bolsas e ver revolvidos os seus pertences. Moça espevitada, esta veio para a viagem disposta a pôr em xeque todas as legislações. E assim o fez, todo o tempo, insuportando qualquer enquadramento: invadiu a cabine do avião, recusava-se a tomar seus remédios, espiava os garotos que faziam xixi na rua, adiantava-se em relação ao grupo ou obrigava todos a esperá-la - seu descompasso era impositivo. Naquele momento da revista aeroportuária, ela tentou negociar: jogou os palitos de fósforo no lixo e disse que queria apenas a caixinha, como suvenir. A guarda foi irredutível “- é proibido." Vasculhou toda a bolsa da moça, e retirou-se, com seu afeto glacial, levando a caixa e mais alguns frascos com líquidos. Ao recolher seus objetos espalhados na 
mesinha, a moça estava furiosa, e não teve dúvida: furtivamente recolheu, junto a seus pertences, uma das luvas da guardacontroladora-de-fronteira esquecida na mesa: suvenir! A guarda estava ao lado, distraida em sua suposta soberania. A moça saiu, batendo os pés corredor afora, carregada do objeto da transgressão, descarregada do objeto eleito do seu afeto. Ninguém a interditou. Atrás dela (depois de tê-la acompanhado e protegido de eventuais riscos de maior violência), assistir a tal cena levava a sorrir, satisfazia contemplar aquela perversão boba que demarcava a estúpida perversão daqueles regramentos ineficientes, descabidos e incompetentes. Alguma estranheza se mantinha no mundo, algo girava em falso, a partir daquela situação em que, entre o controle e a subversão, nada triunfava.

Distâncias. A experiência de passar vários dias juntos, em viagem, considerando a singularidade do grupo não é nada simples. A proximidade borrada, que inúmeras vezes resvala numa conjugalidade domesticada e domesticadora, é parte do grande risco de dizimação deste coletivo, enunciado de diferentes formas por cada um, no mesmo momento em que emergem suas potências: “- parecia que cada um ocupava o lugar do outro: eu ocupava o lugar dela, ela ocupava o lugar dele, ele ocupava o meu lugar... cada um ocupou um pouco o lugar do outro.", foi o comentário de um dos atores, que assim continuava: “ - lá ficou mais clara a diferença de cada um."

O final de uma viagem, de uma temporada, até mesmo de um ensaio, aciona despedidas derradeiras - não há certeza do próximo encontro. Ao contrário de uma mera evidência de insegurança ou falta de confiança, essa hesitação declara uma consistência, a textura impalpável desta constelação: um grupo, uma comunidade que só confirma sua existência na presença de outrem, ainda que esta presença designe a iminência de sua dissolução, a proximidade inextinguível da morte é o que 
comprova paradoxalmente essa vida em conjunto. Com isto, ao invés de uma utopia fusional, o que sobrevém é uma capacidade de estar só, solidão daqueles que "não revelam apenas a recusa de uma sociabilidade envenenada, porém são o chamamento para um tipo de solidariedade nova, o apelo por uma comunidade por vir." (PELBART, 2008b, p. 268).

A radicalidade da experiência do outro deflagra a incompletude do eu, no limite de sua desaparição: em mim, só resta o outro. A justa distância, distância que não iguala, que não prescinde das singularidades, diferençante, ela é um achado da solidão.

A "igualdade", um certo assemelhamento real que acha expressão apenas na teoria de "direitos iguais", é essencialmente própria do declínio: o fosso entre um ser humano e outro, entre uma classe e outra, a multiplicidade de tipos, a vontade de ser si próprio, de destacar-se, isso que denomino páthos da distância é característico de toda época forte. A tensão, a distância entre os extremos se apagam até atingir a semelhança... (NIETZSCHE, 2006, p. 87)

Uma viagem em comunidade, excursão de um grupo, delírio coletivo, qualquer que seja a designação que se atribua, trata-se de algo que desafia a possibilidade de colocar-se ao lado e encontrar a melhor distância - aquela que não sufoca, que não toma o lugar do outro, que não empreita seus trânsitos. Uma companhia simpática é o que se pretende, vizinhança que reconhece a proximidade mas também, e talvez principalmente, a lonjura, que não quer pautar os outros por si mesmo, que não pretende mudar nem transformar ninguém, e no entanto quer favorecer outros encontros, oferecer convites para a experimentação de outras coisas.

"Não-se-sentir-em-casa" ou "pobreza de experiência" esse é o incongruente do comum. Para Virno (2008) esta seria uma experiência baseada na falta, não fosse a força de seu lado convexo, no qual se aloja uma potência: "a superabundância de mundo". 
Esse conhecido-comum não é, porém, familiar: não se parece em nada com uma tradição ou um costume, a repetição emblemática da experiência pobre, não se limita, por outro lado, a separar o comum do habitual, mas afirma o primeiro em detrimento do segundo. A comunhão exibida pelo "mais uma vez" possui a singular prerrogativa de abolir qualquer familiaridade pegajosa. [...] A pobreza da experiência caracteriza-se, na realidade, pela superabundância de mundo que esvazia e atrofia os "lugares próprios", junto aos quais se encontravam papéis estáveis, identidades duradouras e costumes familiares. (VIRNO, 2008, p. 93-4)

Cheios de mundo, só transitoriamente se pode reconhecer algo que se põe em comum na justaposição de relações deste grupo, acentuada pela convivência nas viagens. Se se tratasse de uma comunidade constituída, fusional e familiar, ninguém poderia sentir-se estrangeiro, pois uma casinha nos acompanharia por onde quer que fôssemos, soberania do estar-junto. Engodo. O estar-junto não é soberano, simplesmente porque ele não é um estado. Ele é um desejo, que permanece desejo, nem realizado nem frustrado, uma sensação que uma vez acolhida, conduz aos mundos desconhecidos, que são todos os mundos, e que assim permanecem.

Terminadas as viagens, a logística - precária ou não, e o esforço de sustentação e reparação permanecem imperceptíveis para a maior parte do grupo, senão dissolvidos na experiência comum. A continuidade do grupo que não se pode, mas se quer garantir, fica inundada por sensações e compreensões díspares. A separação iminente coloca a todos num estado de suspensão, que aos poucos adentra o esquecimento, diante da resiliente capacidade de retomada do tempo ordinário, que se impõe a todos. Para muitos, este retorno dirige-se para zonas esvaziadas, núcleos domésticos de esterilidade - seja por desamparo, seja por sufocamento -, que dispara sensações de aniquilamento e dispersão sofríveis. A outros, portadores plenos da identidade $e u$, retomar a vida diária significa reconhecer que, uma vez fora daquela constelação coletiva, a formatação de distinção 
individual e privada rapidamente reflui, e isso dispara desejos por uma espécie de esquizofrenia - que em nada refere-se a uma idealização da loucura ou do louco, mas à vontade de esquecer de si, e ao invés de ser normal como os outros, ser com eles, ser só.

Certamente, estes distanciamentos indiciam uma outra clínica, na qual o pacto, sempre por cumprir-se, exige dos que ocupam a posição instituída de terapeutas que suportem ao menos duas condições inevitáveis nesta constelação: uma, a de normais - figuração identitária num cenário de instabilidade, espécie de carapuça que obriga a representar, não sem indagar, a ordem e os parâmetros da vida pública; outra, simultânea e de algum modo decorrente e contradicente da primeira, a de aliados do desvio, responsáveis por zelar pelas fendas, para que subsistam os abrigos e as ousadias e insubordinações necessárias. Através de uma "atenção impessoal, no sentido de que não é atenção de ninguém, mas a própria espera do que está em jogo" (BLANCHOT, 2007b, p.198), o cuidado prevalecente é o de manterse vinculado ao estrangeiro, ao desconhecido. Silêncios, uma mão forte que por vezes contém, uma escuta que flutua, um corpo ao lado simplesmente presente, gritos, um olhar ligeiro, uma conversa longa, uma ausência ressonante, um passeio, uma comida partilhada, uma bronca, uma gargalhada... são estratégias errantes, tateamentos para oferecer esta atenção que não agarra, que não quer convencer. Atenção que colabora para o descanso e o ajuste tanto quanto para a transgressão vital; que favorece o recolhimento e do mesmo modo a subversão daqueles mesmos parâmetros, codificados em registros aparentemente imutáveis, dos quais se tinha tornado representantes. Trata-se de um ultrapassamento do limite, que paradoxalmente é inultrapassável, a transgressão que "designa aquilo que está radicalmente fora do alcance: a espera do inacessível, a transposição do intransponível" (BLANCHOT, 2007b, p. 190). Essa parceria, inicialmente estereotipada na imagem do terapeuta- 
normal ao lado do paciente-louco, pode - e por vezes assim se efetua - devolver ao mundo, e aos desse mundo, algo de sua comum exterioridade, algo que desmonta essas identidades fixas e borra suas fronteiras, abre alguns poros, e restitui ao mundo aquilo que se subtrai completamente quando nele impera a pasmaceira tamponadora da normalidade e da adequação, vertelhe "a intimidade não familiar do pensamento" (BLANCHOT, 2007b, p. 198), a extrema proximidade dessubjetivada e capaz de regular distâncias que permitam viajar para longe e, sem muita dor, preservar-se, em conjunto, estranhos no desconhecido. 
EXPERIMENTO VI

General Intellect - por onde anda a deficiência?

4x0 para o São Paulo sobre o Palmeiras. 3x1 para o São Paulo sobre o São Caetano. 2x1 para o São Paulo sobre o Corinthians. 3x0 para o São Paulo sobre o Goiás. Uma gritaria infernal na recepção. Dia de encontro do Ateliê Experimental ${ }^{31}$.

Quase toda semana era assim, e cada tentativa de fazer cessar aquele ruído, e fazer compreender que haviam salas com estudantes em aula, era praticamente inútil. Um passo de recuo daquele que mais gritava e ele dava continuidade aos berros, desafiando a ordem e insistindo na comemoração exagerada, na tentativa de entrosar-se com os que ali trabalham, estudam e passam. Às vezes gritava sozinho.

Muitos manejos ensaiaram-se, na busca por uma relação que incluísse acolhimento e delimitação. Um deles desdobrou-se no agendamento de um jogo de futebol como atividade do projeto. Organizações todas feitas: reserva de quadra, autorização de entrada no clube da universidade, divisão dos lanches para um pic-nic depois, todos ansiavam o dia da partida. Passada uma semana, a partida tomou outro sentido: morte súbita. A chuva não deu trégua.

Para dar conta da frustração coletiva fez-se uma roda de conversa, e um desenho forte se apresentou: uma coincidência ou uma elaboração concreta em seu limite? Assim, o tema da morte surgiu como uma onda crescente. Avultou-se tanto, que a viabilidade da condução do trabalho, para terapeutas e estagiários da equipe, ficou ameaçada de encobrimento, estávamos prestes a nos afogar.

O percurso da conversa: o pai de uma das participantes, que foi para o hospital e não morre porque é ruim; o pai de outro participante que morreu no hospital; o pai de um outro ainda que 31 Trata-se do mesmo projeto mencionado no Experimento I. 
morreu no acidente não se sabe qual; o pai de mais um outro que suicidou-se por causa de dívidas; e o pai que não morreu, mas devia ter morrido, mas que faz o rapaz chorar ao pensar nisto e dizer que quer encontrar com ele; o pai que infartou; o pai que teve um derrame mas não se dá conta de que é o pai. Parecia um colóquio para a declaração da paternidade falha, o compartilhamento de um desfuncionamento comum. Havia uma solidariedade naquela lista de pais ladeira abaixo. Por isto sustentamos a conversa por um tempo. Suficiente para até mesmo algumas sugestões se fazerem em relação à compra de caixões para enterro, do corpo do pai e também de membros amputados. Mórbida conversa, e pareciam estranhamente entusiasmados.

A configuração do grupo não é psicoterápica, mas é evidente que as associações em torno de uma atividade (ou da não realização dela) estão liberadas. A duração desta conversa foi amparada por uma decisão no bojo do funcionamento habitual de todas as atividades propostas grupalmente: investigação das motivações, verificação da viabilidade, exploração dos entendimentos possíveis. Entretanto, conforme o traço da conversa se demarcava com maior veemência, tornavase evidente a escassez de estratégias conjuntas para acercar-se daquela dinâmica, em que o que se mostrava era a necessidade de falar do pai, e de suas mortes ou falências, sem que se desmanchassem os contornos mínimos que sustentam a precariedade destas relações. Em algum tempo era possível avaliar - pela inquietação de uns, pelos olhares e acenos de cabeça de outros, e também pela verborragia de outros ainda, que a continência estava tornando-se insuficiente e um transbordamento era iminente. Neste dia, em que não houve jogo, o melhor rumo era a interrupção. Débil de recursos, foi inevitável apelar à metáfora da situação, um jeito tosco de tentar conduzir o movimento de modo a que aquele coletivo e cada um dos que o compunha pudesse acomodar aquela densidade: 
O jogo de futebol morreu hoje, mas a gente pode jogar outro dia. Vamos agendar para outra semana que conseguirmos a quadra. Mas este jogo aqui, está muito difícil... esta conversa... quase mais difícil do que jogar futebol, para quem não sabe jogar futebol...

Eu te ensino, Erika! Eu te ensino!

Acho que eu estou aprendendo... Mas penso que precisamos suspender um pouco esta conversa difícil e importante em que nos metemos agora. Quem sabe uma atividade corporal, e na próxima semana a gente segue com conversando isto, se a gente quiser?

Silêncio.

Antes, alguém quer ainda falar mais alguma coisa?

Eu.

Pode falar.

O que você quer falar?

Falar... com o corpo!

Então, vamos.

Nenhuma objeção. E uma confirmação, talvez. Quanta insegurança para o terapeuta ansioso por uma "devolutiva", um retorno qualquer, um sinal de que por aí pode ser... Diante de um arranjo tão capenga, nada, nenhuma expressão de alívio, nenhuma rebelião. Uma argumentação frouxa que não foi refutada. A conversa simplesmente cessou e fomos fazer ginástica e depois dançar, e depois tomar um lanche, e depois planejar o desenho, e depois fazer bonecos e depois ir embora, e depois voltar na semana seguinte... E depois. E depois do comando? As terapeutas vão ordenando o que se deve fazer, o que se pode fazer, acuadas muitas vezes pela responsabilidade de conduzir, ou ainda mais, de fazer viver, deixar viver aquilo que todos parecem querer vivo. Querem vivo e entretanto deixam que outrem cuide. Passividade que deixa instável 
qualquer intervenção, qualquer interferência num curso. A condução de um grupo com estas características (compostas provavelmente também pelas marcas da pobreza e da deficiência mental e/ou das histórias de sofrimento mental grave) não permite que o terapeuta se distraia em relação à domesticação, ao adestramento. A todo instante, entrevê-se um lugar de manipulação derivado desta passividade predominante. Contudo, ela também evidencia um outro modo de proceder, ou uma certa renúncia indireta às solicitações e aos encaminhamentos, enunciação daquele que está, simultaneamente, destituído e desobrigado do eu. Ela é também uma oportunidade de o terapeuta escapar de seu próprio voluntarismo, e fruir o pertencimento a esta constelação fugaz, com a qual está comprometido e à qual pode subitamente não mais pertencer.

Na paciência da passividade, eu sou aquele que qualquer um pode substituir, o não-indispensável por definição e que, todavia, não pode se dispensar de responder por e para o que não é: uma singularidade forjada e fortuita - a do refém (como fala Levinas), que é o fiador coagido, não escolhido, de uma promessa que ele não fez, o insubstituível que não detém seu lugar. É pelo outro que eu sou o mesmo, o outro que sempre me retirou de mim mesmo. O Outro, se ele recorre a mim, é como a alguém que não sou eu, o primeiro que aparece, ou o último dos homens, em nada o único que eu gostaria de ser; é com isso que ele me destina à passividade, se endereçando, em mim, ao próprio morrer.

(A responsabilidade de que sou encarregado não é a minha e faz com que eu não seja eu.) ${ }^{32}$ (BLANCHOT, 1983, p. 35)

32 Tradução livre do trecho: "Dans la patience de la passivité, je suis celui que n'importe qui peut remplacer, le non-indispensable par définition et qui toutefois ne peut se dispenser de répondre par e pour ce qu'il n'est pas: une singularité d'emprunt et de rencontre - celle de l'otage en effet (comme parle Levinas) qui est le garant non consentant, non choisi, d'une promesse qu'il n'a pas faite, l'irreplaçable qui ne détient pas sa place. C 'est par l'autre que je suis le même, l'autre que m'a toujours retiré de moimême. L'Autre, s'il a recours à moi, c'est comme à quelqu'un qui n'est pas moi, le premier venu ou le dernier des hommes, en rien l'unique que je voudrais être; c'est en cela qu'il m'assigne à la passivité, s'adressant en moi au mourir même.

(La responsabilité dont je suis chargé n'est pas la mienne et fait que je ne suis pas moi.) 
A adesão à atividade proposta em nada denota resignação. As experiências no Ateliê Experimental movem-se na criação de intervalos onde cabe o inusitado de suas constelações. Diante das propostas, cada um deste conjunto é visto num eclipse de passividade e espreita. Sem debater-se contra, nem brandir aceitação, as ações enunciadas são tomadas em sua imanência, como possibilidades de cravar-se no instante coletivo: é como se todos entendessem que para estar-junto é necessário fazer algumas coisas, sem que isto se torne compulsório. E este entendimento não é localizável, ele é apenas uma "levada", como se diz em linguagem musical, quando sons percussivos encontram-se em contratempo e criam um ritmo comum. Isto parece extremamente vago e difícil de precisar, por tratar-se de uma matéria bastante impalpável, da qual se tem apenas algumas sensações e pequenas explosões de acontecimentos.

A coexistência da passividade e da espreita decidem que esta experiência não pode alojar-se na esfera das produções, ela não é produtiva. A suposta "melhora" dos participantes, esperada pelos familiares que os trazem ao serviço de saúde, só se vê na presença de cada outro do grupo, e na satisfação de voltar para um novo encontro. Este movimento está longe de ser glorioso, com efeito, ele se situa esquivo às decisões de um eu consciente que, temeroso ou obediente, cordato ou ressentido, resolveria resignar-se ou aderir. Se há um lugar aproximativo que definiria este movimento, ele seria a ausência de decisão, o estado de passividade liberado de obrigações e de recusas, um estado de arte, imagem possível para aquilo que "nos oferece enigmas mas, felizmente, nenhum herói” (BLANCHOT, 2005, p.39). Esta arte vale para a clínica, na medida da impossibilidade de qualquer situação tornar-se modelo, pois a resposta que cada um encontra, furtivamente, à pergunta que muitas vezes ignora, não serve, sequer convém a outrem.

Há anos trabalhando com algumas técnicas de atividade, o grupo torna-se adepto das chamadas estratégias ocupacionais - 
seja por condicionamento, seja por desejo -, e o que se percebe é que os exercícios com estes fazeres fortalecem menos os seus usos ou desempenhos, e muito mais o próprio funcionamento coletivo. Neste sentido, a ocupação seria aquilo que maquina o enigma deste estar-junto.

Longe de qualquer encantamento, lançar mão de uma atividade, no campo da terapia ocupacional, é a estratégia preferencial para o manejo de qualquer situação de tratamento. Ocupar. Vários estudos, práticas e políticas de saúde muito colaboraram para o deslocamento da dimensão do ocupacional contraposto à ociosidade e/ou inabilidade, que seriam supostamente motivo de adoecimento e desajuste social e, por conseguinte, justificativa para abordagens moralizadoras e funcionalizantes. $O$ pensamento da ocupação em seu viés terapêutico modificou-se em relação a suas origens asilares que consideravam o uso de uma atividade como portador de um valor em si mesmo, pelo simples fato de preencher, não importava como, o tempo ocioso do desajustado, do doente. Muitos estudos e práticas já deram conta de modificar este cenário da profissão e de seu território de conhecimentos. Mas é sim ocupar ainda o que se faz, predominantemente, mas já num espaço indeterminado, cujas expectativas emergem pontualmente, e que não visa a um aprendizado instrumental, nem a uma intervenção sobre materiais, é muito mais uma ação política, uma interferência nos modos de relação.

Uma entre tantas experiências em Terapia Ocupacional, caudatária destas mudanças conflituosas que retiram o tratamento à saúde dos lugares de confinamento disciplinar, o Ateliê Experimental, não é um modelo, nem uma resposta para este conflito. Como outros projetos de origem semelhante, ele vê-se acuado num paradoxo, entre a domesticação e o exercício do comum, uma relação ambivalente com a necessidade de emancipação - exigência de ser -, e a oferta de tecnologias exigência do fazer. Agrupados, os participantes do Ateliê 
Experimental não se atiram em iniciativas nem em consentimentos, e encontram-se, provavelmente, tal qual a enunciação de Blanchot sobre a obra de arte, "nem livres, nem privados de liberdade, como se ela nos atraísse a um ponto onde, esgotado o ar do possível, oferece-se a relação nua que não é um poder, que precede até mesmo a toda possibilidade de relação." (2005, p. 39). Exigência sem exigência. Talvez por isto, durante anos, sempre me angustiava a possibilidade de que o grupo se esvaziasse. A cada dia me deslocava até o local marcado, planejava algumas proposições e ficava vigilante, aguardando temerosa que não houvesse a quem encontrar... Mas eles sempre vinham, muitos, quase sempre todos. Cotidianamente esta era a minha surpresa: espécie de milagre da duração deste agenciamento coletivo, do desejo de estar-junto, as tais "pequenas explosões de acontecimentos".

Um tal "milagre" estendia-se aos momentos em que algumas formas irrompiam de uma atividade, delatando um entendimento que só se faz quando estão todos juntos. Que apreensão é esta, que não se apreende? A alegria de conformar um objeto (desenho, fotos, boneco), uma cena (dança, teatro, jogo) ou uma situação de convivência (lanche, jantar, roda de conversa), ainda que efêmera, instaura o grupo num estado cognitivo desconhecido para a maioria.

Reavivar, neste ponto, o fato de que a maioria dos participantes do projeto têm diagnósticos de deficiência mental, parece uma estratégia grosseira, entretanto, por sua materialidade, ela dá maior visibilidade a este "milagre" do entendimento, "um esperado imprevisto." (VIRNO, 2008, p.151), em que viabilizam-se num coletivo, tanto o ser quanto o fazer, sem garantias de continuidade, potentes em sua volatilidade.

A concepção de general intellect tal qual abordada por Paolo Virno (2008) a partir das teorias marxistas, corrobora com a incongruência na relação com o intelecto tomado na chave individual. 
Por general intellect é preciso entender, ao pé da letra, intelecto em geral. Ora, em si mesmo, Intelecto-em-geral só constitui "partitura" em sentido amplo. É claro que não se trata de uma composição específica tocada por um incomparável músico competente, mas de uma simples faculdade, ou melhor, da faculdade que torna possível toda composição (mas também toda experiência). A execução virtuosística, que nunca dá lugar a uma obra, nesse caso não pode nem mesmo ser pressuposta. Ela consiste no fazer ressoar o Intelecto em sua condição de vocação. A sua única "partitura" é, como tal, a condição de possibilidade de todas as partituras. Esse virtuosismo não é de fato incomum nem requer qualquer talento raro. (VIRNO, 2008, p.126-7)

$\mathrm{O}$ virtuosismo de que fala Virno, advém de uma faculdade que não se determina geneticamente, mas nas relações, em seu caráter público, que depende da "presença alheia" para efetuarse. Com isto, ele alarga a concepção marxista de intelecto "capacidade científica objetivada" -, e dá relevo a um outro aspecto, "à parte pela qual o general intellect [...] se apresenta enfim como atributo direto do trabalho vivo, repertório da intelligentsia difusa, partitura que junta uma multidão" (VIRNO, 2008, p.126).

Presente na constelação do Ateliê Experimental, este desajuste da relação com o intelecto, principalmente neste vórtice da deficiência mental (também chamada deficiência intelectual), conforme já mencionado, interrompe as continuidades do pensamento clínico, seja aquele que a subjuga a um lugar de inferioridade e que pressupõe abordagens de compensação, seja aquele que tenta ignorar sua concretude e lhe exige normalidade, travestida de igualdade. Ambas as perspectivas atravessam as relações a todo o tempo nos atendimentos, e a única saída encontrada refere-se a assunção desta instabilidade numa posição de atenção terapêutica que não admite definir-se numa única direção. Configura-se uma abordagem em deambulação: ora mais para lá, ora mais pra cá. Preocupada em elaborar diversamente as questões para esta relação, sem pretender resolvê-la. Sempre fazendo junto, ora um tanto mais, ora um tanto menos. Ora um passo atrás, ora dois a frente, ora de cima pra baixo, ora de baixo pra cima. Sempre 
lado a lado, em paralelo, preservando a todo custo a possibilidade de que hajam distintos lugares, e que o outro possa ser outro.

Considerando o intelecto enquanto "partitura que junta multidão", sem fazer obra, a disposição para este trabalho precisa ser de conjunto, num "agir-de-concerto".

O general intellect é o fundamento de uma cooperação social mais ampla do que aquela específica do trabalho. Mais ampla e, ao mesmo tempo, completamente heterogênea. Enquanto as conexões do processo produtivo se baseiam na divisão técnica e hierárquica das funções, o agirde-concerto com base no general intellect move-se da comum participação à "vida da mente", ou seja, do preliminar compartilhamento de habilidades comunicativas e cognitivas. (VIRNO, 2008, p.127)

A passividade nas relações - esta condição involuntariosa que faz com que as ocupações se efetivem sem adesão ou oposição - é virtuosa na medida em que não seja servil, não se domestique. O bruto, o selvagem não se caracteriza pela violência. Alguns participantes do Ateliê Experimental ainda não sabem meu nome. Esta capacidade dessubjetivada, atenção sem preensão, sem clausuras, vislumbra-se neste estar-junto. Com o que se pode dizer que aquilo de que o grupo se ocupa inscrevese na dimensão da ação política, uma "ação como arrojada subtração" (VIRNO, 2008, p.131), que questiona as capacidades de comando, que comporta a desobediência, a resistência, a intemperança, o milagre e a amizade.

Passam dias e eu o vejo ali junto ao caixa da banca de revistas. Usa um óculos com aro fino dourado, a boca de lábios flácidos fica entreaberta para por ali respirar e os cabelos parecem sempre por cortar. Toda vez uma mesma pergunta: "quer uma sacolinha”. Ele reconhece os números do preço das revistas, e os dita a alguém que o deixou sozinho mas que está vigilante, e corre para sobrepor-se a sua atividade de me atender. Evidentemente, nós resolveríamos o problema da compra 
juntos: ele apertaria os números na calculadora, provavelmente, veria o resultado, eu daria o dinheiro e o ajudaria com o troco, não por benemerência, mas por interesse recíproco num certo mundo. Onde está, então, a incapacidade para executar sozinho a tarefa de cuidar da banca de revistas? Está, provavelmente na grande possibilidade do engano, não o engano dos números, nem o da genética ou o das más condições de gestação, de parto ou de nutrição, mas o acontecimento enganoso, aquele em que um dos elementos envolvidos trapaceia e constela um evento triste: neste caso, um evento que condena um outro ao lugar absoluto da deficiência mental.

A figura da deficiência mental é uma imagem de intensidade para evidenciar que, uma vez que ela apresenta um impedimento concreto em relação a algumas potencialidades da mente e, portanto, materializa suas limitações, diante dela, todo o entorno vê-se incapaz de uma reorganização e mostra-se também deficiente, mentalmente, no que concerne a sua indisposição ao aprendizado, a sua incapacidade de encontrar uma linha de fuga que viabilize o "agir-de-concerto", o estar-junto. Não por acaso, os modelos de tratamento predominantes voltados à deficiência mental restringem-se a tecnologias de estimulação e treinamento, sempre presumindo a limitação, que individualiza o problema, e supõe que a coletivização depende apenas de mediações tecnológicas, coercitivas (indicadas desde o alto conhecimento científico). Isto torna a deficiência mental um absoluto, uma condição totalizadora, em que alguém está sempre pressuposto aquém de alguma possibilidade de existir e de fazer.

As relações da multidão, de "muitos", de "quaisquer", são heterogêneas, potentes e enganosas, sem representantes para o acerto ou o erro. O Ateliê Experimental é talvez um exemplo disto, que mensura-se pela capacidade de "salvaguarda das formas de vida e das relações comunitárias experimentadas ao longo do caminho" (VIRNO, 2008, p.146). Ele não se pretende um modelo de 
intervenção e não aspira ser fórmula de abordagem grupal. Ele é uma ideia, cuja ação política só é paradigmática quando "capaz de faiscar uma nova combinação de conhecimentos, propensões éticas, técnicas, desejos.” (VIRNO, 2008, p.141)

$\mathrm{Na}$ história do cachorro, que o grupo do Ateliê Experimental inventou para fazer uma animação em stop motion, os personagens foram nomeados de modo insólito: alguns mais genéricos ("o homem", "o cachorro", "o passarinho", "o outro homem"); uma mulher que dava comida para o cachorro era a "rita lee" - celebrizada às avessas; e ainda um nome distorcido, as "pessorrinhas" (pessoas misturado com cachorros?) que "sentiam lágrimas". Num determinado momento alguém foi contando e disse "daí eu fui lá prender o cachorro". "Eu". Era a personagem mais estranha e a mais familiar. “- Eu quem?” “- Eu que estou contando a história”. Ah! O "eu" dele fazia parte daquela história. No jogo da atividade, irrompia esta realidade impositiva, simulacro de uma confiança de ser sempre um mesmo para o outro, ilusão de completude, admissão de uma unidade reificadora que não serve para nada e entretanto nos ocupa: é a morte, nossa passividade comum. 
Ausência. "O esquecimento é uma prática, a prática de uma escritura que profetiza porque se cumpre renunciando a tudo: anunciar, é renunciar talvez." (BLANCHOT, 1980 , p. 122) Nem a obrigação de lembrar, de fazer com que se apresente, nem o esforço de esquecer, de fazer com que se ausente, trata-se de esquecer o esquecimento, terreno do involuntário e do desviante, que permite que haja o pensamento, que acontece fora e não pode confinar-se.

\section{Desobramento - estratégias de interferência e ocupação}

- A ciência! Só existem cientistas, meu caro, cientistas e momentos de cientistas. São homens... tateamentos, noites maldormidas, bocas amargas, uma excelente tarde lúcida. Sabes qual é a primeira hipótese de toda ciência, a ideia necessária a todo cientista? É que o mundo é mal conhecido. Sim. Ora, pensamos muitas vezes o contrário, há momentos em que tudo parece claro - onde tudo é pleno, tudo é sem problemas. Nesses momentos não há mais ciência - ou, se quiseres, a ciência está realizada. Mas em outras horas nada é evidente, existem apenas lacunas, atos de fé, incertezas; só vemos cacos e irredutíveis objetos, por toda parte.

Monsieur Teste, Paul Valéry

O texto que versa a vida errante assim é. Seu pulso é andante, dizem: ritmo moderado - "o mais lento no largo" (WISNIK, 1989, p. 19). Insuficiente e ultrapassado em relação às movências de que tentou falar e das que já se sobrepuseram enquanto empreendia esta tentativa, o texto não faz obra. Ele é a negação da obra, e portanto sua própria negação. Nisto reside sua potência, esta potência qualquer, que importa por ser o seu sentido mesmo e ao mesmo tempo não ser nada. Para a escritura deste texto, muitas leituras, de outros tantos escritos foram feitas, elas estão espalhadas nele, atravessando-o e permitindo que ele possa existir. A partir destas mesmas leituras, muitos outros escritos já foram feitos, e outros tantos hão de fazer-se. Considerando esta combinatória incessante de desdobramentos, encontrar a tonalidade precisa para finalizar este texto é, talvez, deparar-se com sua impossibilidade de acabamento. Todavia, 
em não podendo acabá-lo há que suspendê-lo. Para tanto, devese assumir as configurações que ele pôde atingir, afirmá-las, e do mesmo modo as muitas outras que ele deixou escapar, mais ou menos potentes que as que vingaram.

Desalinhada na cronologia da experiência, a primeira cena: uma forte pressão dentro e fora que deixava o corpo quente, parecia inchado. Muita força precisou ser empregada para adaptar as ferramentas aos parafusos a serem desatarrachados. Força muscular. E outras forças. Era sextafeira, dia de trânsito intenso e alguns congestionamentos. $O$ barulho feito durante a desmontagem daquela grande e pesada arquibancada ainda estava vibrando no espaço, junto ao do teste dos microfones para a conferência da noite, e mais o dos carros que passavam cada vez em maior número pela Avenida Paulista. "Tamo no centro do poder de São Paulo!", alguém gritou. Eram muitas as reverberações nestas duas semanas juntos. Muitos encontros em torno de uma montagem teatral: Finnegans Ueinzz ${ }^{33}$, que trazia consigo a justaposição de línguas e linguagens, de ficção e verossimilhanças. Cada encontro desdobrava pensamentos e gestos, e com eles resistiase nos lugares comuns: ocupando-os e desertando-os. Na proeminência das situações diárias, para a cena de desfazimento deste lugar concretizado do público de um espetáculo teatral foram empregados os mais extensos gestos experimentados até ali. Era, sem dúvida, o mais braçal dos tantos esforços disparados e sustentados naqueles dias em torno do desejo de questionar a disposição estanque de quem supostamente faz a arte e de quem a recebe.

Qual o procedimento da questão? Provavelmente, aquele que busca liberar o pensamento da posição de Espetáculo "retrato cumprido da Publicidade" (TIQQUN 1, 2001, p. 24), elemento

33 Projeto da cia. teatral Ueinzz, um 'working process' apresentado pela primeira vez em novembro de 2008, dirigido por Cássio Santiago com a colaboração de Elisa Band. 
de estetização da vida que corresponde a sua inscrição já dada e que, ao mesmo tempo, a inscreve reiteradamente na cultura do consumo e da visibilidade forjada, e deixa materialmente evidente que, em relação ao Comum, o homem está alienado. Decalca-se o homem sobre seu mesmo, seu idêntico, sob ares de diferente e socializante, e nisto ele se encontra numa linha indefinível, tal qual a figura do Bloom, o ser qualquer, o sem qualidades, prestes a, sem o saber, qualificar-se - tomado de assalto por alguma pronta identidade.

No Espetáculo, o poder está em toda parte, quer dizer que todas as relações são, em última instância, relações de dominação. Por esta razão, também, ninguém aí é soberano. É um mundo objetivo onde cada um deve, primeiramente, submeter-se, para por sua vez submeter. Viver conforme a aspiração fundamental do homem à soberania é aí impossível, exceto num instante, exceto num gesto. ${ }^{34}$ (TIQQUN 1, 2001, p. 39)

A oportunidade de ocupar um lugar no centro, centro do poder da cidade, da cultura, é também uma armadilha óbvia de desconexão com o menos visível ou, até mesmo, invisível a que um coletivo esteja vinculado. O paradoxo desta condição é a matéria que torna estas experiências tão caras à escritura deste texto, que versa o indizível da experiência clínica, através de uma escrita paralelística, que rompe com o pensamento por unidades e faz a letra cotejar com a vida na medida deste jogo arriscado com a marginalidade. No caso da cia. teatral Ueinzz, suas oportunidades de apresentação pública estavam localizadas num registro menos espetacular na rede cultural e, principalmente no mercado das artes, isto quer dizer: espaços alternativos, apresentações pontuais, infra-estrutura precária de divulgação e produção etc, sobretudo por tratar-se de um projeto que relaciona artes e loucura. Este conjunto de características

34 Trad. livre do trecho: "Dans le Spectacle, le pouvoir est partout, c'est-àdire que tous les rapports sont en dernière instance des rapports de domination. Pour cette raison, aussi, nul n'y est souverain. C'est un monde objectif où chacun doit d'abord se soumettre pour soumettre à son tour. Vivre conformément à l'aspiration fondamentale de l'homme à la souveraineté y est impossible, hors d'un instant, hors d'un geste." 
determinariam, à primeira vista, este projeto como marginal. Entretanto, sabendo que esta margem é uma figura de jogo, o deslocamento para espaços culturais centrais, ou seja, lugares socialmente reconhecidos pelo mercado cultural, coloca esta experiência de algum modo numa encruzilhada que pode-se chamar de uma "fama marginal". Obter a aprovação de uma instituição proeminente no sistema cultural, significa alojar-se, ainda que temporariamente, numa posição de usura capitalística, e com isto flertar com a sociedade do espetáculo, cujo funcionamento habitual consome as experiências da borda à medida que as reconhece e as centraliza. Este consumo é por um lado, a esterilização de sua escassez, de sua pobreza forte - sua palavra muda e sua loucura -, por operações perversas, ocorre uma transformação do pobre em miserável, fazendo-o deslumbrar-se com a ilusão do acesso que lhe retira a possibilidade de estar e de morrer. Por outro lado, é esta mesma posição de uso, de consumo do coletivo, o seu trunfo para a experimentação de mundos, para incremento da sua potência de ocupação e de evasão. Nada, portanto, se estabelece, todavia instabiliza-se.

Antes, logo nos primeiros dias, uma das arquibancadas foi arrastada para um canto do espaço para que o elenco pudesse sentar-se nela durante as apresentações. De frente para a arena, voltada para os demais assentos (constituídos por outra arquibancada, algumas almofadas e cadeiras), os atores não só assistiam a peça em andamento, como também assistiam a quem a assistia, instaurando um primeiro desajuste das posições ator-espectador.

As apresentações ocorriam à noite e, durante o dia, o grupo seguia pensando e refazendo a ocupação daquele espaçotempo do evento em numerosos exercícios: mais sutis, programados, súbitos, indiretos ou mais grosseiros. Na duração 
disto que chamou-se Ocupação Ueinzz ${ }^{35}$ : longos embates com risos, comida, gritaria, devorações, sono, e trabalho, e uma profusão de temas e discussões constantes.

Nomear este evento sob o termo ocupação, segue a esteira reincidente de várias outras manifestações culturais dos últimos tempos, que querem aludir diretamente às estratégias dos movimentos sociais que, reunidos em torno de uma questão decisiva para a vida coletiva, realizam espécies de invasões territoriais a fim de acirrar suas reivindicações. Em geral, estas "entradas desautorizadas" ocorrem diante da recusa à negociação por parte das instâncias de poder, o que leva estes grupos a ocuparem espaços públicos ou privados, interrompendo funcionamentos estanques e obrigando a pautar, de modo continuado, temas de necessidade coletiva que culminam em reabertura de negociações contundentes, em sua maioria, violentas, por vezes, resolutivas, mas sempre alterando o estado vigente das coisas. Evidentemente, menos que por modismo, a Ocupação Ueinzz queria também habitar esse território da política e, através da arte, e instaurar outros modos de relação com o mundo, com a vida. É certo que tanto quanto nobre, esta pretensão também realoja os eventos artísticos que lançam mão dessa nomeação, imediatamente, na dimensão do Espetáculo. Difícil escapar.

Quase ao final do evento - retomando a cronologia factual - é que chegara o momento de desfazimento desta ferramenta, própria do espectador, seu objeto de poder - de poder ver, de poder fixar-se, de poder estabelecer-se, de poder perscrutar, de poder controlar, de poder participar. De algum modo, com a arquibancada desconstruiu-se também o que poderia haver de destaque na posição dos atores, aquilo que os fixaria numa identidade de artistas. Cada pedaço daquele

35 Evento realizado de 09 a 20 de setembro de 2009 na unidade do Sesc da Avenida Paulista, a partir das apresentações da montagem "Finnegans Ueinzz" da cia. teatral Ueinzz que, além delas, constitui-se por filmes, conferências e interferências para a TVSesc. 
objeto imenso, separado de seu conjunto, revirado em outras posições, resultou na vida em cena acontecendo num plano borrado, sem que para isto fosse preciso qualquer estratégia interativa ou apelo espetacular. Todavia, no que pudesse haver ali relacionado a um qualquer outro pensamento do "fora", este também não constituiu-se num absoluto, e por isto não quer e não pode salvar-se da categoria do “mesmo”. Ficou, então, em seu limite, num penúltimo passo antes de sucumbir, tornando-se apenas mais um "elemento essencial da estetização da vida cotidiana processada pela cultura do consumo." (FAVARETTO, 2008, p. 17) - típico nas manifestações contemporâneas.

O transcurso deste texto aglutinado a esta cena da desmontagem da arquibancada, é evidente que não garantem por si só nenhuma legitimidade de resistência política a seus eventos. Entretanto, mesmo no risco de um gesto vigoroso, que facilmente pode tornar-se sensacional e/ou espetacular, o que importa nestas duas instâncias eventuais é "a experiência ela mesma (vontade de ir até a ponta do possível)" (BATAILLE (1954), 2008, p. 24), seus gestos alcançáveis e limitados em seus respectivos tempo e lugar. Seria isto o "inconfessável" da comunidade, enunciado por Blanchot? É este o acontecimento vital, que deve ser dito, mas que ao dizer-se desloca-se para um espaço de estranheza tal que margeia o ínfimo, o horror, o irrisório e a fraqueza? Por onde seguir, ao aceitar o desafio de portar e, quem sabe, prolongar este pensamento?

A comunidade inconfessável: será que isto quer dizer, que ela não se confessa, ou melhor, que ela é tal que não existem confissões que a revelem, já que, cada vez que falamos de sua maneira de ser, pressentimos que só apreendemos dela o que a faz existir à revelia? Então, mais teria valido calar-se? Melhor seria, sem ressaltar estes traços paradoxais, vivê-la no que a torna contemporânea de um passado que jamais pôde ser vivido? O mais célebre e mais retomado preceito de Wittgenstein, "Aquilo de que não se pode falar, deve ser calado". Indica que, uma vez que ele não pôde, ao enunciálo, impor silêncio a si mesmo, é por que em última instância, para calar, é preciso falar. Mas com que tipo de palavras? 
Eis uma das questões que este pequeno livro confia a outros, não tanto para eles a respondam do que para que eles queiram carregá-la e talvez prolongá-la. Achar-se-á, assim, que ela tem também um sentido político exigente e que ela não nos permite desinteressarmo-nos do tempo presente, o qual, ao abrir espaços de liberdade desconhecidos, nos torna responsáveis por relações novas, sempre ameaçadas, sempre esperadas, entre o que chamamos obra e o que chamamos desobramento. ${ }^{36}$ (BLANCHOT, 1983, p. 92-3)

Essa precariedade torna difícil cessar com os experimentos. A abolir a linha tendencial que vislumbra, mesmo que em flashes, a criação de uma totalidade exitosa, reluta-se também. Na escrita de cada narrativa evidenciam-se marcas da clínica, das artes, do desobramento (aquilo que em sua obra a faz resistir a tornar-se obra, que interrompe sua conclusão em obra, e evita finalizar-se). A atividade de narrar impõe-se - esta espécie de força que reconhece na escrita um modo de fazer que passa pela invenção de experiências por meio de uma prosa a um só tempo ficcional e verossímil. A narração força os fluxos necessários para deixar passar o pensamento e constelar outros territórios para a clínica (e seus encontros em que se vive e se pode viver em comum), um plano onde não hajam setas prioritárias, em que suprimem-se os protocolos e, sem militância, evoca-se a liberdade. Nisto a proposição de uma comunidade da escritura encontra seu sentido, enquanto estratégia de interferência e desobramento: em lugar de edificar um relato, uma descrição supostamente científica e/ou um prontuário de verdades, a narrativa da clínica aproxima-se da

36 Trad. livre do trecho: "La communauté inavouable: est-ce que cela veut dire qu 'elle ne s'avoue pas ou bien qu'elle est telle qu'il n'est pas d'aveux qui la révèlent, puisque, chaque fois qu'on a parlé de sa manière d'être, on pressent qu 'on a saisi d'elle que ce qui la fait exister par défaut? Alors, mieux aurait valu se taire? Mieux vaudrait, sans mettre en valeur ses traits paradoxaux, la vivre dans ce qui la rend contemporaine d'un passé qui n'a jamais pu être vécu? Le trop célèbre et trop ressassé précepte de Wittgenstein, $<<$ Ce dont on ne peut parler, il faut le taire $>>$. Indique bien que, puisqu'il n'a pu en l'énonçant s'imposer silence à luimême, c'est qu'en définitive, pour se taire, il faut parler. Mais de quelle sorte de paroles? Voilà l'une des questions que ce petit livre confie à d'autres, moins pour qu'ils y répondent que pour qu' ils veuillent bien la porter et peut-être la prolonger. Ainsi trouvera-t-on qu'elle a aussi un sens politique astreignant et qu'elle ne nous permet pas de nous désintéresser du temps présent, lequel, en ouvrant des espaces de libertés inconnus, nous rend responsables de rapports nouveaux, toujours menacés, toujours espérés, entre ce que nous appelons oeuvre et ce que nous appelons désoeuvrement." 
fábula, "um falar que não sabe aquilo que diz antes que um deciframento o preveja de uma significação e de uma utilidade" (CERTEAU, 1982, p.203). Experimentar contar é, seguindo este rastro, espalhar aquilo que precede as significações e qualificações utilitárias de um evento, antecipar-se em afirmar sua descontinuidade.

Num diagrama riscado a giz no chão do espaço cênico, apresentaram-se idéias em paralelo que, no cruzamento de latitudes e longitudes, encontrariam-se em forma de pergunta. Quem disparava estes movimentos era Alejandra Riera - dando continuidade ao projeto "Enquête sobre o/nosso entorno",37. Desta vez, junto à cia. teatral Ueinzz, visava-se instaurar o que ela denominara "lieu(x)détudes" - "lugares de estudos" (numa tradução simplificada que não dá conta do jogo do " $x$ ” - plural de "lugar" - que, colocado entre parêntesis e emendado à expressão "de estudos", aludia a alguma tensão: versus).

Lieu(x)détudes se fixa para pensar, de um ponto de vista nem expert nem sociológico, a maneira pela qual nossa relação com as ferramentas e de um modo mais geral com as máquinas com as quais nós vivemos e através das quais produzimos nosso trabalho, recortam as formas de nossas percepções e as enquadram nos sistemas de valorização. A intenção seria estender estas fronteiras aparentemente intransponíveis até a invenção de outros instrumentos de percepção, e de valorização e de transmissão, da história do presente. (RIERA, 2009, p. 3)

O trabalho assemelhava-se a uma imersão delirante de conexões inusitadas entre tempos e espaços... Seguiam-se seus exercícios. Sentados elou caminhando, o grupo funcionava em torno de peças separadas que antes, juntas, faziam funcionar uma outra máquina: um computador. Ora no chão, ora numa bancada dispunham-se: teclas com letras, teclas com funções, ventoinha, dispositivos de memória, caixa de proteção, disco rígido, tela, equipamento para $c d$, teclado, pedaços de fio... As

37 Este projeto, desenvolvido conjuntamente por Alejandra Riera e a cia. teatral Ueinzz iniciou-se em 2005 e foi mencionado neste escrito, por ocasião do Experimento 4 e 5. 
mesmas peças que serviam para fazer operar um computador agora faziam operar a máquina de ocupar da cia Ueinzz e seus agregados. Junto às peças, uma porção de aparatos para olhar: peneira, cristal, lentes, escumadeira, pulseiras, lata, tecidos, papéis furados. E um monte de fotografias, penduradas em fios. $O$ "lie(x)détudes" demarcou-se em pautas. Sob formas diversas que variavam entre leituras, improvisações e discussões, em cada um dos encontros, o grupo avançava em relação a alguns temas. Motes que enunciavam o mundo e a propriedade daquele ajuntamento de pessoas, de ideias e de teatro, naquele lugar e naquele tempo. Experimentações para tentar certificar-se da existência de algo que não era possível saber se existia de fato, aquilo que parecia tratar-se de uma espécie de comunidade, mas que só poderia conhecer-se quando não mais existisse.

Pauta: "O zero e o um” - procedimento binário que faz com que a máquina possa decodificar a palavra e disseminar discursos. Quando o zero toma lugar, ganha um assento significativo, o vazio se estabelece num signo e perde um tanto da tonalidade de sua abertura a infinito. "O que teria (nos) acontecido se o fato de distinguir um lugar vacante não tivesse se tornado um número? (RIERA, 2009, p. 6).

Cena: Numa mesa encontravam-se alguém que dizia "coisas prosaicas", e outro alguém que ao ouvir tais coisas, com uma colher de pedreiro, aplastava a tela do computador, peça isolada, sustentada por duas pessoas, em cada um dos lados. Num determinado momento, alguém outro entrava em cena, tomava a colher de pedreiro em suas mãos, e num gesto súbito submetia a tela à horizontalidade da mesa, aludindo a sua platitude.

Pauta: "A tecnologia predominante" - que substitui e elimina os usos e os pensamentos associados a outras ferramentas $e$ instrumentos. $O$ instrumento de captação universal $e$ 
hegemônico - a câmera de vídeo - era questionado em sua apreensão domesticadora, que instaurava um enquadre para o olho que acabava por naturalizar-se, sem que se pudesse pensar outros aparelhos de captação: uma peneira, um cristal, uma chave, uma furadeira manual, um pedaço de tecido em tela.

Visita: Um vendedor de ferramentas em meio ao grupo, mostra alguns dos instrumentos de sua coleção, destaque especial a uma serra maleável utilizada pelos soldados alemães da segunda guerra mundial para abrir caminho derrubando grandes árvores manualmente.

Pauta: "O que se guarda do que se olha?" ${ }^{38}$. A proposta de criar interferências na forma de pequenos vídeos para a TV convocava a pensar em como não render-se à captura do quadrado televisivo, sem eliminá-lo, mas de modo a fazer dentro dele emergir outras formas que o subvertessem $e$ devolvesse a quem olha a multiplicidade do olhar.

Movimento proposto: todos até a janela e por alguns segundos olhar. Ver pela janela conforme a consignia, e ver os guardas que olhavam pela janela, por ser inevitável. Eles foram convidados a estarem neste trabalho do grupo quando estavam de folga do serviço de vigilância do próprio local em que o grupo se encontrava. Os guardas que guardam o que olham, ali junto a outros que sentem-se guardados e vigiados, seguros e expostos, protegidos e reféns do olhar destes que são contratados para guardar.

Pauta: "Montagem e seleção de imagens:" como se faz, quem sabe e quem pode fazê-lo. Um trecho de 10 minutos de um filme de Godard - "Ici et Ailleurs" - foi mostrado. Quem conta a história do presente. Qual história conta? Um grupo de pessoas seguram imagens da guerra em fila, e as expõe à câmera pelo

38 Em francês, a formulação trazida por Alejandra Riera era mais evidente pela proximidade de composição das palavras guardar [garder] e olhar [regarder] "Qu'est-ce qu' on garde de ce qu' on regarde?" 
tempo que aquele que carrega a imagem seguinte decide: o da frente deve sair quando o de trás lhe cutuca os ombros. A sucessão dos quadros, as frases-vinhetas que lhes acompanham, o tempo de exposição que minimiza seus efeitos, que impede sua apreensão, apenas lhe toma mas não se deixa tomar.

Pauta: "O domínio dos discursos, domínio do saber."

O Saber significa em parte "fazer saber que se sabe", presumir saber o que os outros não tinham ainda calculado como saber, não tinham ainda sabido, ou desejado tornar escrita, esta escritura da história tão bem apropriada pelos diferentes progressos dos instrumentos de transmissão expansionista de um saber legislativo. Escrever, neste sentido, é encarregar-se dos outros. (RIERA, 2009, p.12.)

Cena: Uma cirurgia se iniciava, com as convidadas-cirurgiãs, que noutros momentos eram as mulheres responsáveis pela limpeza do espaço ocupado pelo grupo. Elas extraiam do corpo deitado na mesa, as peças do computador desmontado. Cortavam o tecido, arrancavam as peças e liam. Um trecho de Artaud foi lido:

Quando tiverem conseguido um corpo sem órgãos, então o terão libertado dos seus automatismos e devolvido sua verdadeira liberdade. Então poderão ensiná-lo a dançar às avessas, como no delírio dos bailes populares e esse avesso será seu verdadeiro lugar. (ARTAUD, 1986, p. 161-2)

E na roda de conversa, uma das cirurgiãs explicou que o corpo, ao dançar, faz com que os órgãos migrem ao lado esquerdo e então este fica sendo o lado mais perfeito, o lado correto: o lado direito.

Pauta: "De quem é a voz que pode fazer-se voz diante de outrem?" Os espaços de discussão eram frequentes e intensos, $e$ na maior parte do tempo era o próprio lugar de enunciação o que estava questionado. Assim, aquela que estava muitas vezes à frente deste lugar, com o propósito mais imediato de coordenar a atividade deste questionamento, era confrontada 
com o paradoxo entre sua posição e aquilo que através dela enunciava. Eram momentos importantes, em que algo do que estava sendo dito, podia ser vivido, mantendo-se a capacidade de pensar, embora os ataques mais agressivos fossem por vezes inevitáveis.

Situação: Em meio a algumas referências e motes para a conversa, uma das participantes da roda acusa: “- Você faz estas colocações porque você tem condições de pensar isto." E diante de uma resposta algo como: “- Eu não sei, tanto ou menos do que qualquer um de vocês. Estou querendo fazer este estudo junto para saber junto alguma coisa que não sei.”, a participante retruca: “- Se você não soubesse mais que eu, não estaria em pé aí à frente e eu aqui sentada diante de você." E o aparente desfecho vem em palavras mais ou menos assim:"Troquemos de lugar. Seu comentário é perfeito. Obrigada, eu precisava que alguém me tirasse dali..." Mas a participante se constrange, pede desculpas... Nada se resolve. Continuamos juntos, entre impasses e passes, travessias, expressões, hierarquias, pontos de obscuridade e não-ditos. Mantém-se o compromisso com não sei quem e com qualquer um, e se permanece só...

Tem razão quem em algum momento bradou que tratava-se de uma utopia. Utopia, porque num não-lugar. Nenhum dos elementos dispostos edificaria um lugar: nem avenida paulista, lie(x)détudes, finneganns, cia. teatral Ueinzz, clínica, loucura, arte... Nada. Ninguém. É impossível que o lugar de enunciação se esvazie, e que ninguém se coloque nele, tanto quanto é impossível não verificar nisto um uso e um abuso do poder de dizer. Apenas o silêncio, talvez..., contivesse a enunciação, aquela que não enuncia, necessária ao comum que se queria experienciar ali, não se sabe onde.

Nas derivas finais deste escrito, ao evocar mais uma narrativa, e não resistir a este impulso de novamente fabular, 
parece apelar-se a um caminho óbvio e inseguro. Entretanto, de fato, ao persistir nesta direção, o texto quer acolher um trajeto impositivo de acabamento, diante de um modus operandi que elegeu este fluxo: o da letra a contar, a experimentar com o vivido e a interferir nos formatos habituais de enunciação da clínica. Deste modo, busca-se intensificar, com mais esta experimentação, os acrescentamentos e subtrações que o texto pode oferecer a seus virtuais leitores - aqueles com quem fará, sem o saber, comunidade: a "comunidade desobrada" deste escrito.

Insistir em contar não garante sua legitimidade. A este respeito, no já mencionado prefácio de Jeanne Marie Gagnebin ao livro O que resta de Auschwitz de Agamben (2008), há um assinalamento que convém retomar:

um livro sobre a dificuldade do testemunho. [...] como todos os livros de "testemunhas" [...] trata-se de narrar "o que aconteceu" e de afirmar, ao mesmo tempo que "o que aconteceu" não faz parte do narrável. (GAGNEBIN, 2008, p. 11)

Alçar-se a dizedor do indizível, parece ser a condição de responsabilidade de quem sobreviveu ao decidir escrever de acontecimentos de uma vida comum, pois dispor-se como testemunha de uma experiência abismal, de dissolução do $e u$ e suas identidades - seja por extermínio violento, seja por abertura insondável - é prova irrefutável de não ter sucumbido à experiência e, portanto, não tê-la vivido até sua consumação. $\mathrm{O}$ que se conta é então aquilo que foi vivido por outrem. Disto, o campo de concentração é a ponta mais radical e concreta, e suas intrínsecas figuras - do sobrevivente e do muçulmano - são a imagem da indizibilidade de uma situação-limite. Equivalente do qualquer - aquele que importa de todo modo -, bem como do Bloom - produto de um mundo com o qual não se sente ligado de nenhum modo ${ }^{39}$-, o "muçulmano" seria ainda um personagem

39 O "louco" também poderia ser um personagem a alinhar-se nesta série, tomado em sua caricatura social. "O louco antes de tudo é àquele que "não sabe" (não vê o que é, não fala o que é, não sabe o que fala, não 
magistral do desparecimento do eu, único vivente do abismo sem retorno da experiência, aquele que o impediu de continuar viver, mas que o tornaria proprietário exclusivo da legitimidade para contar o que aconteceu. Não tivesse ele se extinguido junto ao acontecimento teria-se a narrativa absoluta, a continuidade total da história.

Ou como figura nosográfica, ou como categoria ética, ou alternadamente como limite político e conceito antropológico, o muçulmano é um ser indefinido, no qual não só a humanidade e a não-humanidade, mas também a vida vegetativa e a de relação, a fisiologia e a ética, a medicina e a política, a vida e a morte transitam entre si sem solução de continuidade. Por isso, o seu "terceiro reino" é a cifra perfeita do campo, do não-lugar onde todas as barreiras disciplinares acabam ruindo, todas as margens transbordam. (AGAMBEN, 2008, p. 56)

Só o "muçulmano" poderia narrar o secreto do que aconteceu, entretanto, quem o faz é o "sobrevivente", a personagem outra, aquela que por não ter dado o último passo em relação à experiência, não lançou-se em seu abismo, e por isto retornou e sofre da convocação imprescritível de contar o que não viveu. Se tivesse vivido teria sofrido da dissolução cabal, e não se poderia contar dela, a morte o teria calado. Assim como o inconfessável de Blanchot, em Agamben "o testemunho vale essencialmente por aquilo que nele falta" (AGAMBEN, 2008, p.43). Não se trata de arrolar o acontecimento no âmbito de uma mística privilegiada, senão de uma crítica estreitamente ligada à vida. Aos saltos, acompanhando o pensamento de Agamben, vemos esta separação produzida pela "ambição do biopoder", figurada entre "o muçulmano" - o ser vivo do acontecimento, a zoé, não-homem; e o "sobrevivente" - o ser que fala do acontecimento, o bios, o homem -, coincidirem numa só figura,

sabe o que vê, não sabe que não sabe, acredita no que percebe embora não perceba o que vê, e percebe mais do que vê), que "não pode" (gerir bens, ser eleito, situar-se numa relação de forças, ter autonomia, sujeitarse a um trabalho, obedecer, respeitar, ser adequado), que "não é sujeito" (desestruturado, sem centro, Nome-do-Pai forcluído, não se relaciona consigo mesmo, nem com os demais)". (PELBART, 1989, p. 164) 
este "arcano" cuja "divisão insuperável” é que permite que haja o testemunho.

O testemunho não garante a verdade fatual do enunciado conservado no arquivo, mas a sua não-arquivabilidade, a sua exterioridade com respeito ao arquivo; ou melhor, da sua necessária subtração - enquanto existência de uma língua tanto perante a memória quanto perante o esquecimento, Por isto mesmo - por ser possível dar testemunho só onde há a possibilidade de dizer e só haver testemunha onde houver uma dessubjetivação - o muçulmano é realmente a testemunha integral, e por isso não é possível separar o muçulmano do sobrevivente. (AGAMBEN, 2008, p.157-8).

Numa perspectiva abusada, que perverte os termos e os associa de um modo um tanto selvagem, vale a pena dizer que a noção de comum é o elemento que reúne as figuras do vivente e do sobrevivente mantendo-os divíduos. Paradoxal situação que, em proporções de multiplicidade, transportam-se aqui para as experimentações do campo clínico, narradas neste escrito. $\mathrm{O}$ campo de concentração deve ser tomado como o sinalizador eloquente dos campos que nos habitam todos. Por isto podemos falar, escrever, sermos autores que, tal qual, em entrevista, Lyotard declara:

[...] tentam fazer nas palavras (outros tentam na pintura, no cinema, ou na música) testemunho daquilo que não é escrevível, pintável ou musicável... e isto é o importante, o verdadeiramente importante, isto é o que constitui a honra de pensar: tentar colocar-se à altura do Acontecimento desse algo inapreensível... ${ }^{40}$ (LYOTARD, 2007, p. 2).

Ao render-se a esta contingência, engendrada pelo seu próprio percurso, a fabulação reiterada deste texto intenta definir-se numa forma contributiva a uma clínica na qual intervém elementos das artes e da filosofia, considerando que o constructo deste escrito é o método para sua própria decomposição, seu projeto de obra e sua impossibilidade de fazer-se obra, ou ainda a "obra erigida sob sua própria dissolução" (PELBART, 2008c, p.

40 Trad. livre do trecho: “[...] intentan hacerse en las palavras (otros intentan en la pintura, en el cine, o en la musica) testigo de aquello que no es escribible, pintable o musicable... y esto es lo importante, lo verdaderamente importante esto es lo que constituye el honor de pensar: intentar ponerse a la altura del Acontece de ese algo inaprensible..." 
29). E esta condição incômoda, é também seu devaneio, sua loucura.

Os experimentos aqui apresentados foram fabulados como testemunhos de acontecimentos coletivos de sentido para uma clínica que é política na medida em que se diferencia de outras (portanto, supõe uma multiplicidade de perspectivas) e define uma posição singular. Entretanto, qualquer um daqueles que participaram destes eventos, e que os quisesse contar, estaria sob ao menos dois riscos inseparáveis: o de desfazê-los; e o de reinventar sua existência para prolongar sua duração. A distância diametral deste escrito em relação ao fazer científico recai sobre esta modalidade de uma experiência-limite: entre o fazer-se e o desfazer-se, contrária à "tranquila continuidade discursiva", subtraindo-se aos esforços de unificação e totalidade, pautados em princípios da razão e do entendimento, que fazem predominar realizações identitárias e de exclusão (BLANCHOT, 2001, p. 35-6). A cada avanço em relação à composição de um conjunto unitário, que oferecesse encadeamento lógico ao leitor, sobrevém a avalanche da língua, que tudo preenche ao mesmo tempo em que tudo devasta: seu excesso é sua indigência. Desobramento. Tradução forçada que tenta abarcar em sua sonoridade o movimento que desfaz a obra.

Desoeuvrement em francês significa, literalmente, ociosidade, preguiça, inação, isto é, um estado alheio ao trabalho e a seu fruto, que é a obra. O desoeuvrement em seu sentido usual fala de alguma passividade, evoca uma lassidão e até talvez um tédio. Contraponto da obra, entendida como dialética do trabalho diurno, o desoeuvrement não poderia ser apenas sua oposição simétrica, assim como a morte se opõe à vida. $\mathrm{O}$ próprio termo, por seu sufixo, lembraria uma ação. Mas como uma inação, uma não-obra pode adquirir o caráter ativo? Como a passividade pode tornar-se ativa conservando seu caráter de passividade? Que passividade é essa, ativa, efetiva e operativa? Que positividade poderia haver nessa ausência de obra que faz dela um ato, isto é, nem uma ausência propriamente dita, nem uma obra? (PELBART, 1989, p.80) 
Da inoperância da qual decorre o desobramento - sua outra tradução - à conhecida acepção de Foucault que contrasta loucura e obra, e diz que onde ocorre uma não ocorre a outra, Blanchot acrescenta "a ausência de obra, um outro nome para a loucura" (BLANCHOT, 2001, p.72). Ao primeiro exame, esta ausência corresponderia à imagem de um vazio paralisado. Entretanto, o "desoeuvrement" é o fazer do desfazer, gesto impessoal e involuntário que interrompe os fluxos incessantes dos encerramentos e das clausuras do pensar. Sobrevém então, tomar a noção de ocupação - incluindo-se aí a vertente da clínica que comporta a existência do campo profissional denominado terapia ocupacional -, e colocá-la em justaposição com este gesto "passivo" que ocupa toda obra até abolir sua presença.

De uma ocupação a outra, este alinhamento seria, sobremaneira, simplista. Todavia, interessa alcançar seu aspecto mais complexo para privilegiar neste enredamento sua perspectiva estratégica - ferramenta ainda possível e quiçá potente, para problematizar e inaugurar aberturas no pensamento desta temática que, somadas às coordenadas deste escrito-mapa, colaboram para finalizar seu traçado. Com isto, a ideia de ocupar o tempo é transportada e apartada de sua conotação de utilidade contraposta ao ócio ${ }^{41}$, para ser tomada como algo a ser reinvestigado, a fim de anarquizar seus usos e gerar interferências em seus entendimentos. Perverte-se sua eficácia e se a dispõe ao instante sem origens e sem finalidades. Não se trata de um elogio ao nada, à inação ou ao vazio, sequer uma proclamação hedonista, senão a explicitação da miserabilidade

41 Esta perspectiva que desmonta a visão da ocupação como estratégia de preenchimento do tempo ocioso, tem sido analisada em muitos estudos no campo da Terapia Ocupacional, entretanto, o que se vê, em geral, são reconduções que mantém-se atreladas a verbos como fazer, gerar, mover, agir, criar, reinvindicar, discutir etc que transportam-se a dimensões que ainda privilegiam os aspectos produtivos e reiteram as ditas "ações humanas" como motivo e argumento da saúde e até mesmo da existência do homem, seja através de práticas artísticas, sociais ou terapêuticas stricto sensu. 
de uma condição submissa e restrita da vida, ao útil e ao produtivo.

Simplesmente elegi viver: a cada instante me surpreendo ao ver homens ardentes e ávidos por atuar que se burlam do prazer de viver. Esses homens confundem, obviamente, a ação com a vida, sem chegar a ver nunca que se a ação é o meio necessário para a manutenção da vida, a única aceitável é a que se apaga, ou melhor, que a rigor se presta a apagar-se diante da "diversidade centelhante" da qual você [René Char] fala, que não pode e nunca poderá ser reduzida ao útil. [...] Ninguém poderia condenar a ação, senão mediante o silêncio - ou a poesia -, abrindo a janela até o silêncio. Denunciar, protestar, segue sendo atuar, é ao mesmo tempo ocultar-se frente as exigências da ação. (BATAILLE, 2001, p.137-8).

Disciplinar ou de controle, a dimensão ocupacional nas sociedades ainda reza pela comunicação com o mundo mercantil, e em sua interface contemporânea ela se assume numa ditadura de produções: sejam materiais ou imateriais, finalizadas ou processuais.

Liberar a ocupação de seu sentido utilitário, contraposto à falta do que fazer, permite assumir uma posição diante do vazio, do nada, em que o não ter que fazer é tomado como um poder estar ocupado, ser ocupante de uma duração. Isto recuperaria o poder das zonas de contato sem finalidade prévia ou às bordas de um suposto objetivo. Mais ainda, interessa o pensamento do ocupar enquanto aquilo que nos acontece e que simultaneamente fazemos acontecer: somos ocupados enquanto ocupamos. Vice-versa. "[...] jamais ocupar o lugar daquele ou daquela que 'representa', mas deixar espaço para que outros, enquanto sujeitos (com os quais escolhemos fazer um caminho), se autopresentem, ocupem um lugar" (RIERA apud CIA. TEATRAL UEINZZ, 2009). Não haveria possibilidade de determinação do protagonismo, mas de posições: é preciso estar numa posição ativa para receber e doar, deixar passar através e atravessar o que nos passa, atualizando a potência destas posições.

O lugar em que algo se passa dificilmente é aquele programado para isto. Um grupo, na clínica, que esteja às voltas com uma atividade, vai provavelmente experimentar-se naquilo 
que ocorre em torno desta atividade, como se ela fora o pretexto para poder efetuar-se uma ocupação consistente, vital de um lugar que só se constela episodicamente. A habilitação para um fazer pouco advém de sua educação, de seu cultivo, e muito mais dos buracos, das fendas por onde pode escapar o que não quer cultivar, o que não quer estabelecer-se em continuidades.

Ocupar no sentido de habitar, de fazer esse lugar - um entre tantos outros que atravessamos - um refúgio temporário onde, ocupar-se dele, tomar conta dele, nos incumbiria a todos. Enfim, ocupar no sentido de estar apaixonado(a)s por. Tempo, espaço, corpos presentes serão assim tocados por diferentes modos de estar presente (RIERA, 2009, p. 3).

O viés "ocupacional" da vida pode liberar-se de uma oposição forçosa e criar uma via afirmativa interessante, alinhando ocupar/habitar/vagar entre vazios, operar espaçotempo/ etc. $\mathrm{O}$ entendimento das "máquinas de guerra" resgata o verbo ocupar relacionando-o à ocupação política, na clínica, nas artes, na vida.

[...] buscar um estatuto para as "máquinas de guerra", que não seriam definidas de modo algum pela guerra, mas por uma certa maneira de ocupar, de preencher o espaço-tempo, ou de inventar novos espaços-tempos: os movimentos revolucionários, mas também os movimentos artísticos são máquinas de guerra.” (DELEUZE, 1992, p. 212)

Movimento de torção do ocupar, esta parataxe suspende este escrito, que esfacela-se no conceito de desobramento, seu argumento, sua proposição silente - cara a todo seu percurso -, e condição impeditiva de conclusões, sua morte comum.

Diferencial para a clínica, como um lugar de operações políticas, é também a proposição do desobramento contribuição para não fazer obra, sobretudo não fazer da vida do outro sua obra. Na iminência de uma obra inevitável, a experiência da clínica, seu suposto arcabouço de conhecimentos, seria o narrável de seus eventos, aquilo que emerge de seus movimentos, o vivencial que pode versar-se, e não tornar-se obra. Resta-lhe narrar esta sua desobra, lugar comum, o menos 
comum do mundo, que desemboca aqui num assinalamento para uma comunidade de escritura, a partir de comunidades de distância e delicadeza. Conjunto efêmero de escritores que só falem quando inevitável e que não o façam em nome, nem a serviço de nada - nenhuma causa nobre -, nem de ninguém nenhum sujeito decadente (desfavorecido, fraco ou em desvantagem). "A vida tão precária: jamais presença de vida, mas nossa eterna prece a outrem, para que ele viva enquanto nós morremos.” (BLANCHOT, 1980, p.136)

As evidências da clínica, e de outros ofícios que deságuam comportamentos, e pretendem oferecer condições para que uma vida se dê, não são elementos representáveis em linhas escritas, não podem ser descritos como se fossem alcançáveis por outrem que não aquele que esteve lá, aquele que vive aquela vida, que morre aquela vida, que percebe-se de algum modo naquele corpo que é sempre de outrem. Com ele só se pode estar em comum. As evidências recolhidas pela técnica, são evidências, não evidentes, são verossímeis, mas não irrefutáveis, são elementos apenas videntes. "[...] antes ou depois do "político" há isto: a saber, o "comum", o "conjunto" e o "numeroso", e talvez já não sabemos em absoluto como pensar esta ordem do real." (NANCY, 2007, p. 22-3). Nesta comunidade da escritura, escrever desta abundância impalpável é um modo de testemunhar sua presença. Mas, a comunidade da escritura não é um ente, ela não é nada senão a possibilidade da existência deste testemunho.

Nem um sujeito coletivo, nem um conjunto de sujeitos. Senão a relação que já não os faz ser tais - sujeito individuais - porque interrompe sua identidade com uma linha que os atravessa alterando-os: o "com", o "entre", o umbral sobre o qual eles se cruzam em um contato que os relaciona com os outros na medida em que os separa de si mesmos. (ESPOSITO, 2008, p.39).

A atividade da vida humana é a desobra de sua vida própria, o contato abismal com seu comum não-pertencimento. Esta travessia de dessubjetivação pode experimentar-se, na 
clínica, em direções diversas que vão desde as que radicalizaram os aspectos químico-biológicos e outras que investiram em hibridações de territórios, por exemplo as aproximações da clínica e da loucura com as artes e a cultura, acercamento abordado em sua complexidade nos experimentos deste e de outros escritos.

Assim, mesmo que a arte, a clínica e a loucura, tivessem mantido sua singularidade - pois são irredutíveis umas às outras, procedendo por meios próprios e respondendo a suas questões específicas -, não cessaram de interferir entre si. Os múltiplos atravessamentos entre os campos, produziram mutações em cada um deles, como se, de alguma forma, tivessem sido implodidos como blocos monolíticos e isolados do conjunto das práticas sociais e passassem a se cruzar em outros tantos territórios. (LIMA, 2009, p. 226)

A ideia da intervenção precisa ser reformulada, deste ponto de vista, pois o ofício clínico refere-se muito mais a interferências numa zona de ocupação comum. O cuidador e aquele que é cuidado habitam esta zona comum, num espaçotempo em que as obras serão circunstanciais e provisórias, não pela matéria perecível, mas pela inscrição destas relações no mundo, que estariam suficientemente dessubjetivadas a ponto de não desdobrarem produtos nem instaurarem processo algum, apenas ondas resultantes de alguma frequentação instantânea.

O caráter da intervenção que vê-se coadunado ao conhecimento nas formas de relação entre analistas, clínicos e pesquisadores, muitas vezes é tomado como sinônimo de interferência. Entretanto, ao apostar-se no "caráter sempre intervencionista do conhecimento" em que, "em qualquer de seus momentos todo conhecer é um fazer" (PASSOS; BARROS, 2000, p.74), tem-se uma proposição que, embora não desarticule a teoria e a técnica, ainda recorre a estratégias para responder aos modos de relação em vigência, ou seja, que pressupõem demandas e produções em trânsito, dentro de um processo clínico em que sujeito e objeto não se encontram em posições pré nem pós estabelecidas, havendo misturas interessantes, mas que 
permanecem numa ação continuada. Considera-se, neste âmbito que "a intervenção, como procedimento de aproximação com o campo, mostra-nos que ambos - pesquisador e pesquisado, ou seja sujeito e objeto do conhecimento - se constituem no mesmo momento, no mesmo processo.” (PASSOS; BARROS, 2000, p.73).

A pragmática, mesmo em termos de imagem para $o$ pensamento, de uma tal diferença - entre a intervenção e a interferência -, é de difícil realização. A concepção da Física pode ajudar a reforçar este viés da noção de interferência no sentido de uma intromissão: uma onda que, eventualmente, em suas oscilações, frequenta outra onda, ao estar, por instantes, na mesma frequência que a outra. É uma relação não programada e inevitável, tanto quanto o é o fim inesperado desta justaposição. Um ocupa o outro: simplesmente ocupação, porque seus movimentos ondulatórios assim o exigem. Forçar uma ocupação, buscar produzi-la implicaria um gesto de autoridade, por qualquer parte (mesmo porque pressuporia partes). Não empreitar, não montar empreiteiras. Poder desertar o poder de encarregar-se do outro, representá-lo, fazer voz em seu nome, falar em seu lugar. Mesmo a concepção de escrever sobre o outro fica, com isso, inviável. A atribuição de um mérito de discorrer sobre os acontecimentos da vida de outrem, como se fora possível conhecer e formular metodologias que garantam legitimidade ao escrever o que se passa com outrem, e com isto acumular posses de conhecimento problematiza-se.

De intervenção a interferência. Esse deslocamento modifica o estatuto daquele que se põe ao lado, e esbarra na frequência de outrem. Na chave da intervenção, a posição de ajuda, na clínica, bem como a de propositor, nas artes - aquele que cuida, que se responsabiliza por oferecer algo a outrem -, vira-se ao avesso ao recusar a enunciação positivista de neutralidade científica, e acaba por erigir um subjetivismo no analista ou pesquisador ou artista, que projeta em seu campo de 
ação, princípios e finalidades provenientes de sua inserção social na rede do mundo mercantil, produtivo.

[...] os trabalhos artísticos que funcionam segundo a modalidade do evento, embora pretendendo, inicialmente, interferir, até mesmo dialetizar o meio de arte, isto é, o sistema artístico, convertem-se frequentemente em instâncias de comunicação, em que perdem o valor crítico pretendido, qual seja: provocar um acontecimento localizado, que explorando a força do instante, daria lugar à exploração de signos de resistência, entendendo-se este trabalho como o de explicitação da angústia provocada pela perda do próprio objeto da arte, em virtude do aprisionamento dos objetos e do desejo pelo consumo. Assim, a estetização generalizada é simultaneamente fruto da desestetização moderna e da perda do vigor de nexos e tensões dos dispositivos modernos, como a tensão entre o sensível e o racional, entre construtividade e vivência, por exemplo. (FAVARETTO, 2008, p. 18)

Abdicando da intervenção em favor de interferências deserta-se, portanto, a dicotomia processo-produto: nem processo nem produto, o que se propõe é a desobra, a inoperância, a abulia em relação a qualquer definição totalizadora. Em lugar de interferência, pode-se pensar ainda, nos termos de Agamben, em uma "medialidade pura e sem fim" (AGAMBEN, 2002, p.129). Diferenciando o pensamento que subordina os meios a alguma finalidade, esta medialidade exibida pela política seria o campo efetivo da ação e do pensamento humanos. A modernidade secundarizou o produto, elevando o estatuto dos processos, entretanto, ainda que invertendo a posição de privilégio, prossegue na chave desta relação (processo-produto). Desertar este registro implica sobrelevar a nulidade do gesto político, em seus dispositivos de desmontagem que não são de destruição, mas de afirmação do vazio, da aguda necessidade de deixar vir a vagueza do espaço para os acontecimentos inesperados. Na própria pergunta "como fazer uso do comum?", formulada por Agamben e destacada no início deste escrito, encontra-se uma linha de fuga, aquilo que não é sua resposta, mas uma saída para seus exercícios: o próprio uso, "apropriação de uma expropriação" (AGAMBEN, 
2002, p.130). Não há possibilidade de acúmulo, de produção, apenas de ocupação intransitiva. Ocupa-se. Não há transmissão de experiência, há a experiência comum de uso comum da qual ninguém foi, é ou será proprietário.

Desobramento, inoperância, esquecimento, silêncio, amizade.. Caminhos de formulação para um questionamento político do contemporâneo. Deles desdobram-se algumas indicações para sua clínica [do contemporâneo], com um viés na multiplicidade, na duração e na escrita por paisagem. O próprio modo de escrever esta clínica apresenta os vetores de força que podem servir de referência à composição da geografia de seu pensamento: elementos de delírio, que dilatam a temporalidade, desviam-se dos traumas, desertam as agruras e dramatizam o encontro, oferecendo uma aliança estética que pode contribuir para a invenção de novas éticas.

Alguém dos atores propôs outra designação: "estado independente". E quis acrescentar: "a arte de amar" ao diagrama traçado no chão. Acomodou a expressão na lateral externa aos outros elementos: escrito na horizontal, acompanhando a linha vertical do desenho, um embaralhamento condizente com a singularidade enigmática da proposição.

Do estado independente situações exemplares.

Lembrança: episódio vivido num ônibus quando conversava com uma outra passageira com uma proposta de revolução: mudar todas as casas da periferia, das favelas, ali para a avenida Paulista. "Como seria?", ele indagava. "Vamos invadir o centro do Capital!", gritava. Palavra de ordem, hasteamento de bandeira, encenação ideológica... tudo isto pode ser atribuido a este grito, entretanto, sua reverberação, tremulava as sensações dos presentes, alguns reconheciam gritos anteriores, outros, completamente desentendidos, assustavam-se. Menos as palavras, mais o próprio grito 
importava, espécie de rasgo no sussurrar comportado do dia-adia civilizado. De todo modo, a imagem que apresentava-se era a das bordas ocupando o centro, desta vez não mais como refém do mercado e da publicidade, mas como invasora, numa proposta perversa de interferência radical no andamento instituido. As mobilizações transbordavam no caminhar de cada um, no ir e vir daquele $5^{\circ}$ andar da Avenida Paulista, como se o tempo se sobrepusesse ao espaço e onde quer que se fosse, o que se carregava era aquela suspensão do tempo, ou melhor, aquela duração de um acontecimento, a superfície do mundo daqueles que ali se juntaram imantava-se num instante сотит...

Algo da ordem da soberania, conforme Bataille, ali se dava, espécie de instante miraculoso: "o instante em que a espera se resolve em NADA" (1970-1988, p. 257). Este milagre da possibilidade de liberar a vida, ainda que temporariamente, da necessidade de buscar finalidade, futuro ou utilidade, parecia corresponder àquela experiência.

Com efeito, é o instante em que somos lançados fora da espera, da espera, miséria habitual do homem, da espera que submete, que subordina o instante presente a um resultado esperado qualquer. Precisamente, no milagre somos relançados da espera do porvir à presença do instante, do instante clareado por uma luz miraculosa, luz da soberania da vida liberada de sua servidão. ${ }^{42}$ (BATAILLE, 1970-1988, p. 257)

Relato indignado: fúria e inquietude pela tentativa de propor na fila do Poupatempo ${ }^{43}$ algo dessa liberdade de poder não se sentir refém da "globalização". Um homem respondeu que o problema não era ela [a globalização] mas aqueles como eles ali da fila que não conseguiam acompanhá-la; o homem o

42 Trad. livre do trecho " $C$ ' est en effet l'instant où nous sommes jetés hors de 1 'attente, de l'attente, misère habituelle de l'homme, de l'attente qui asservit, qui subordonne l'instant présent à quelque résultat attendu. Justement, dans le miracle, nous sommes rejetés de l'attente de l'avenir à la présence de l'instant, de l'instant éclairé par une lumière miraculeuse de la souveraineté de la vie délivrée de sa servitude."

43 Programa do governo do estado de São Paulo que reúne em um só estabelecimento vários equipamentos governamentais de prestação de serviços públicos, cuja frequentação é volumosa. 
questionou sobre se ele sabia, por exemplo, mexer na internet, e ao responder que não, o homem concluiu, demonstrando, que era por isto que ele se sentia mal com a globalização, pois, na verdade, o que ocorria era que eles tinham "perdido o trem da história”. Fora da história? Era, para ele, inadmissível. E entretanto aquilo the apossava como uma espécie de condenação, a fala daquele homem da fila o colocara em contato com uma dimensão de horror. No encontro daquele dia na Ocupação, ele rebatia insistentemente todas as propostas, dizendo que o estado independente não existia, que aquilo era utopia, que "lá fora" a vida continuava de outro jeito, e este coletivo não conseguiria fazer a "revolução".

O último passo, a última palavra do texto é, com efeito, a penúltima, uma vez que ela preza (provavelmente, em vão) por não desmontar o agenciamento em que ele fragilmente se instala. Palavra dada no intervalo diferencial entre o "limite" e o "limiar", conforme a enunciação de Deleuze e Guattari “[...] o limite designando o penúltimo, que marca um recomeço necessário, e o limiar o último, que marca uma mudança inevitável.” (1997b, p.130). O limite, portanto, deste escrito, é a sua letra, e seu limiar, talvez, sua leitura. O que lhe resta é a suspensão. Ele não se conclui, e o que se pode entrever nesta respiração interrompida são seus silêncios e algumas reclusões (importantes para interferir no excesso comunicacional que se vive). A sabedoria não é o que se oferece, nem respostas, nem resultados. Se há um "vivo" do texto, ele estará em seu estado de busca.

Toda busca é uma crise. O que é procurado nada mais é do que o giro da busca, que faz acontecer a crise: o giro critica. Isto é desesperadamente abstrato.

- Por que? Eu diria mesmo que toda obra literária importante $o$ é tanto mais que ela põe em funcionamento, mais direta e puramente, o sentido deste giro o qual, no momento em que ela vai emergir, faz estranhamente cair a obra onde se mantém, como seu centro sempre descentrado, a inoperância: a ausência de obra. (BLANCHOT, 2001, p. 72) 
De tudo, por um instante sobrava nada, e com um grito

sem eco, que proclamava a independência em sua impossibilidade de revolução, voltava-se a uma inquieta plenitude... sinal da vertigem em que se estava imerso, provavelmente algo da ordem da embaralhada "arte de amar" (ANTUNES, 2009), enclave possivel da "comunidade dos amantes" (BLANCHOT, 1983).

Comunidade de uma prisão, organizada por um, consentida pelo outro, onde o que está em jogo é, precisamente, a tentativa de amar - mas por Nada -, tentativa que não tem finalmente outro objeto senão este nada, que os anima sem que o saibam, e que não os expõe a nada exceto esse tocar-se em vão. [...] Como não buscar neste espaço em que, durante um tempo que vai do crepúsculo à aurora, dois seres não têm outras razões de existir além da de expor-se inteiramente um ao outro, inteiramente, integralmente, absolutamente, a fim de que compareça, não aos seus olhos mas aos nossos olhos, sua comum solidão, sim, como não buscar aí e como não encontrar aí "a comunidade negativa, a comunidade dos que não tem comunidade"? ${ }^{44}$ (BLANCHOT, 1983, p. 82-3)

Em sua errância fragmentária, em meio a coletividades e solidão comum, quem sabe a desobra deste texto desvaneça-se em uma ou outra desobstrução e possa romper com algumas continuidades invioláveis, e ativar outras saúdes e disposições do espírito. Desejoso por cursar, liberado de telos, um desfazimento dos astros - dos destinos traçados: um desastre, é esta a imagem da passividade do desobramento, cruel e efetivo gratuitamente, o mais à toa amoroso e silenciosamente estrondoso, que tudo arruiná, deixando sobreviver em mim apenas o outro.

44 Trad. livre do trecho: "Communauté d'une prison, organisée par l'un, consentie par l'autre, où ce qui est en jeu, c'est bien la tentative d'aimer mais pour Rien, tentative qui n'a finalement d'autre objet que ce rien que les anime à leur insu et qui ne les expose à rien d'autre qu'à se toucher vainement. [...] Comment ne pas chercher dans cet espace où, durant un temps qui va du crépuscule à l'aurore, deux êtres n'ont d'autres raisons d 'exister que de s'exposer entièrement l'un à l'autre, entièrement, intégralement, absolument, afin que comparaisse, non pas à leurs yeux mais à nos yeux, leur commune solitude, oui, comment n'y pas chercher et comment $\mathrm{n}^{\prime} \mathrm{y}$ pas retrouver $<<$ la communauté négative, la communauté de ceux qui n'ont pas de communauté $>>$ ?". 
[PÓS-TEXTO]

escritos de outrem

\author{
Juntado, \\ por embriaguez seca, \\ tudo o que é qualquer. \\ Então, perseguir a morte deste \\ tudo que é aquilo que confirma, \\ nada comum, \\ que fomos, que estivemos \\ contudo.
}

Quem dera pudesse escrever seu desastre. 
AGAMBEN, Giorgio. La communauté qui vient. Trad. para o francês de Marilène Raiola. Paris: Éditions du Seuil, 1990. [ La comunitá che viene. Turim: Giulio Einaudi editore, 1990.]

A comunidade que vem. Trad. António Guerreiro. Lisboa - Portugal: Editorial Presença, 1993. [La comunitá che viene. Turim: Giulio Einaudi editore, 1990.]

Onde Começa o Novo Êxodo. Trad. Eliana Aguiar. Rio de Janeiro, Rev. Lugar Comum , n. 7, jan-abr 1999.

. Homo Sacer: o poder soberano e a vida nua I. Trad. Henrique Burigo. Belo Horizonte: Ed. UFMG, 2002a. [Homo sacer. Il potere sovrano e la nuda vita. Turim: Giulio Einaudi editore, 1995.]

. Moyens sans fins. Trad. para o francês de Danièle $\overline{\text { Valin e }}$ outros. Paris: Éditions Payot \& Rivages, 2002b.

Infância e História: destruição da experiência da história. Trad. de Henrique Burigo. Belo Horizonte: Editora UFMG, 2005. [Infanzia e storia. Distruzione dell'esperienza e origine della storia, Turim: Giulio Einaudi editore, 1979.]

La comunidad que viene. Trad. para o espanhol de José Luis Villacañas e Cláudio La Roca. 2ed. Valencia Espanha: Pre-Textos, 2006. [La comunitá che viene. Turim: Giulio Einaudi editore, 1990.]

Qu'est-ce qu'un dispositif? Trad. para o francês de Martin Rueff. Paris: Éditions Payot \& Rivages, 2007. [Che cos 'è un dispositivo?. Roma: Edizioni Nottetempo, 2006.]

O que resta de Auchwitz. Trad. Selvino J. Assmann. São Paulo: Boitempo Editorial, 2008. [Quel che resta de Auschwitz. Turim: Bollati Boringhieri, 1998].

O que é o contemporâneo? e outros ensaios. Trad. Vinícius Nicastro Honesko. Chapecó-SC: Argos, 2009. [Che cos'è il contemporaneo? Roma: Edizioni Nottetempo, 2008; Che cos'é un dispositivo?. Roma: Edizioni Nottetempo, 2006; L 'amico. Roma: Edizioni Nottetempo, 2007.]

ANTUNES, Alexandre Bernardes Moreira. Estado independente. (informação verbal) In: CIA. TEATRAL 
UEINZZ. Ocupação Ueinzz. (caderno de anotações). São Paulo: SESC - Avenida Paulista, 2009.

ARTAUD, Antonin. Para acabar com o juízo de Deus. In: Escritos de Antonin Artaud. Seleção e Tradução de Cláudio Willer. Porto Alegre-RS: LP\&M, 1986.

BARTHES, Roland. A aventura semiológica. Trad. Mário Laranjeira. São Paulo: Martins Fontes, 2001. [L'Aventure Semiologique. Paris: Éditions du Seuil: 1985.]

O Neutro. Trad. Ivone Castilho Benedetti. São Paulo: Martins Fontes, 2003. [Le Neutre, Paris: Éditions du Seuil: 2002.]

Como viver juntos: simulações romanescas de alguns espaços cotidianos - cursos e seminários no Collège de France, 1976-1977. Trad. Leyla Perrone-Moisés. São Paulo: Martins Fontes, 2003. [Comment vivre ensemble. Paris: Éditions du Seuil, 2002.]

O grau zero da escrita. Trad. Mário Laranjeira. São Paulo: Martins Fontes, 2004. [Le degré zero de l'écriture. Paris: Éditions du Seuil, 1953]

Aula: aula inaugural da cadeira de semiologia literária do Colégio de França, pronunciada em 7 de janeiro de 1977, 13ed. Trad. Leyla Perrone-Moisés. São Paulo: Cultrix, 2007. [Leçon. Paris: Éditions du Seuil, 1978.]

BATAILLE, Georges. "La Souveraineté" In: Evres complètes. Paris: Éditions Gallimard, 1970-1988, tomos VIII.

La felicidad, el erotismo y la literatura - ensaios 1944-1961. Trad. Silvio Mattoni. Buenos Aires: Adriana Hidalgo Editora, 2001. [Evres complètes, Tome 11 et 12. Paris: Éditions Gallimard, 1988.]

Gallimard, 2008.

L'expérience intérieure. (1954). Paris: Éditions

BENJAMIN, Walter. Magia e técnica, arte e política: ensaios sobre literatura e história da cultura. Trad. Sérgio Paulo Rouanet. 7ed. São Paulo: Ed. Brasiliense, 1994. [Auswahl in Drei Bänden. Frankfurt: Suhrkamp Verlag, s/d.]

BERGSON, Henri. As Duas fontes da Moral e da Religião. Trad. Nathanael C. Caixeiro. Rio de Janeiro: Zahar Editores, 1998. [Les deux sources de la morale et de la religion. Paris, PUF, 1932.] 
BEZERRA Jr., Benilton. O ocaso da interioridade e suas repercussões sobre a clínica. In: PLASTINO, Carlos Alberto (org.) Transgressões. Rio de Janeiro: Contra Capa Livraria, 2002. pp.229-238.

. A noção de experiência e sua importância para a clínica atual. In: ARRUDA, Arthur; BEZERRA Jr., Benílton; TEDESCO, Sílvia (orgs.) Pragmatismos, pragmáticas e produção de subjetividades. Rio de Janeiro: Garamond, 2008, pp. 201-24.

BLANCHOT, Maurice. La Ausencia Del Libro Y Nietzsche Y La Escritura Fragmentaria. Trad. Alberto Drazul. Buenos Aires: Ediciones Cladén, 1973. [L'absence du livre. Rev. L'Ephémère, $\mathrm{n}^{\circ} 10$, París; e Nietzsche y la escritura fragmentaria Rev. Eco, Bogotá.]

1980.

L'écriture du desastre. Paris: Éditions Gallimard,

La communauté inavouable. Paris: Les Éditions de Minuit, 1983.

O espaço literário. Trad. Álvaro Cabral. São Paulo: Ed. Rocco, 1987. [L'espace littéraire. Paris: Éditions Gallimard, 1955.]

Foucault como o imagino. Trad. Ana Luísa Faria e

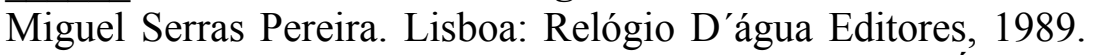
[Michel Foucault tel que je l'imagine. Montpellier: Éditions Fata Morgana, 1986.]

A parte do fogo. Trad. Ana Maria Scherer. Rio de Janeiro: Ed. Rocco, 1997. [Le part $d u$ feu, Paris: Éditions Gallimard, 1949.]

.A conversa infinita 1 - a palavra plural. Trad. Aurélio Guerra Neto. São Paulo: Ed. Escuta, 2001. [L'entretien infini. Paris: Éditions Gallimard, 1986.]

O livro por vir. Trad. Leila Perrone-Moisés. São Paulo: Martins Fontes, 2005. [Le livre à venir. Paris: Éditions Gallimard, 1959.]

Escritos políticos. Trad. para o espanhol Lucas BidonChanal. Buenos Aires: Libros del Zorzal, 2006. [Écrits politiques. Paris: Éditons Lignes \& Manifestes, 2003.] 
La Amistad. Trad. J. A. Doval Liz. Madrid: Editorial Trotta, 2007a. [L'amitié. Paris: Éditions Gallimard, 1971.]

.A conversa infinita 2 - a experiência limite. Trad. João Moura Jr. São Paulo: Ed. Escuta, 2007b. [L'entretien infini. Éditions Gallimard, Paris, 1986.]

BRETON, André. Manifestos do Surrealismo. Trad. Sérgio Pachá. Rio de Janeiro: Nau editora, 2001. [Manifestes du Surrealisme. Paris: Pauvert, 1962.]

Amor Louco. Trad. Luiza Neto Jorge. Lisboa: Editorial Estampa, 1971 (reimpressão de 2006). [L'amour fou. Paris: Éditions Gallimard, 1937]

Nadja. Trad. Ivo Barroso. São Paulo: Ed. Cosac Naify, 2007. [Nadja. Paris: Éditions Gallimard, 1928.]

CASTRO, Edgard. Vocabulário Foucault - um percurso pelos seus temas, conceitos e autores. Trad. Ingrid Müller Xavier. Belo Horizonte: Autêntica Editora, 2009.

CERTEAU, Michel de. A escritura da história. Trad. Maria de Lourdes Menezes. Rio de Janeiro: Forense universitária, 1982. [L'écriture de l'histoire. Paris: Éditions Gallimard, 1975.]

CIA. TEATRAL UEINZZ. Ocupação Ueinzz. (encarte do evento). São Paulo: SESC - Avenida Paulista, 2009.

[CÍCERO] Retórica a Herênio. Prefácio e tradução de Ana Paula Celestino Faria e Adriana Seabra. São Paulo: Hedra, 2005.

DAVID, Catherine. Práticas Artísticas, práticas Políticas?. Registro das Conferências do Encontro Internacional São Paulo S.A. - práticas estéticas, sociais e políticas em debate. Situação \#3 Estética e Política. São Paulo: SESC-Belenzinho, $2005 . \quad$ Disponível em: http://www.sescsp.org.br/sesc/Conferencias/subindex.cfm?

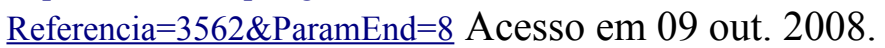

DELEUZE, Gilles. Foucault. Trad. Cláudia Sant'Anna Martins. São Paulo, Ed. Brasiliense 1988b. [Foucault. Paris, Éditions de Minuit, 1986.]

. A dobra - Leibniz e o barroco. Trad. Luis Benedicto Lacerda Orlandi. Campinas-SP: Papirus, 1991, p. 175.

Conversações, 1972-1990. Trad. Peter Pál Pelbart. São Paulo: Ed. 34, 1992. [Pourparlers, 1972-1990. Paris: Les Éditions de Minuit, 1990.] 
O mistério de Ariana. Trad. Edmundo Cordeiro. Lisboa: Veja Ltda., 1996.

Crítica e clínica. Trad. Peter Pál Pelbart. São Paulo: Ed. 34, 1997. [Critique et clinique. Paris: Les Éditions de Minuit, 1993]

Bergsonismo. Trad. Luiz B. L. Orlandi. São Paulo: Ed. 34, 1999. [Le bergsonisme. Paris: Presses Universitaires de France, 1966.]

Lógica do Sentido. 4 ed. Trad. Luiz Roberto Salinas Fortes. São Paulo: Perspectiva, 2000. [Logique du sens. Paris: Les Éditions de Minuit, 1969.]

Francis Bacon: Lógica da Sensação. Coordenação da trad. Roberto Machado. Rio de Janeiro: Jorge Zahar Editora, 2007. [Francis Bacon: Logique de la Sensation. Paris: Éditions de la Différence, 1981.]

Diferença e repetição. $2^{\mathrm{a}}$ ed. Trad. Luís Orlandi e Roberto Machado. Rio de Janeiro, Graal, 2006. [Differénce et répétition. Paris: Presses Universitaire de France, 1968.]

Nietzsche e a Filosofia. Trad. António M. Magalhães. Porto, RÉS-Editora, s/d. [Nietzsche et la Philosophie. Paris: Presse Universitaires de France, 1973]

DELEUZE, Gilles; GUATARRI, Félix. O Anti-Édipo capitalismo e esquizofrenia. Trad. Joana Moraes Varela e Manuel Carrilho. Lisboa: Assírio \& Alvim, 1966. [Capitalisme et Schizophrenie 1 - L'Anti-Oedipe, Paris: Les Éditions de Minuit, 1972.]

. Mil Platôs - capitalismo e esquizofrenia. vol 1. Trad. Aurélio Guerra Neto e Célia Pinto Costa. Rio de Janeiro: Ed. 34, 1995a. [Mille Plateaux - capitalisme et schizophrénie, Paris: Les Éditions de Minuit, 1980.]

Mil Platôs - capitalismo e esquizofrenia. vol 2. Trad. Ana Lúcia de Oliveria e Lúcia Cláudia Leão. Rio de Janeiro: Ed. 34, 1995b. [Mille Plateaux - capitalisme et schizophrénie, Paris: Les Éditions de Minuit, 1980.]

Mil Platôs - capitalismo e esquizofrenia. vol 3. Trad. Aurélio Guerra Neto, Ana Lúcia de Oliveira, Lúcia Cláudia Leão e Suely Rolnik. Rio de Janeiro: Ed. 34, 1996. [Mille Plateaux - capitalisme et schizophrénie, Paris: Les Éditions de Minuit, 1980.] 
. Mil Platôs - capitalismo e esquizofrenia. vol.4. Trad. Suely Rolnik. São Paulo: Ed. 34, 1997a. [Mille Plateaux capitalisme et schizophrénie, Paris: Les Éditions de Minuit, 1980.]

. Mil Platôs - capitalismo e esquizofrenia. vol 5 Trad. Janice Caiafa e Peter Pál Pelbart. São Paulo: Editora 34, 1997 b. [Mille Plateaux - capitalisme et schizophrénie. Paris: Les Éditions de Minuit, 1980.]

DUBUFFET, Jean. Asphixiante Culture [1968]. Paris: Les Éditions de Minuit, 1986.

. Asfixiante cultura. Trad. Miguel Serras Pereira. Lisboa: Fim de Século - Edições Sociedade Unipessoal Lda., 2005.

ESCOSSIA, Liliana; KASTRUP, Virgínia. O conceito de coletivo e a superação da dicotomia indivíduo-sociedade. Rev. Psicologia em Estudo. Maringá, v.10, n. 2, mai./ago. 2005.

ESPOSITO, Roberto. Communitas. Origen y destino de la comunidad. Trad. Carlo Rodolfo Molinari Marotto). Buenos Aires: Amorrortu, 2003. [Communitas. Origene e destino della comunità. Turim: Giulio Einaudi editore, 1998.]

Nihilismo y comunidad. In ESPOSITO, Roberto;

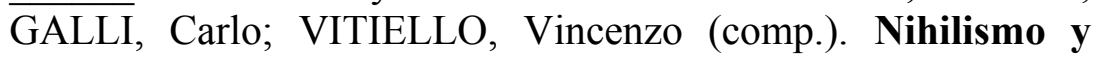
política con textos de Jean-Luc Nancy, Leo Strauss, Jacob Taubes. Trad. Germán Prósperi. Buenos Aires: Ediciones Manantial. 2008.

FARIA, Ana Paula Celestino; SEABRA, Adriana. Introdução. [CÍCERO] Retórica a Herênio. Prefácio e tradução de Ana Paula Celestino Faria e Adriana Seabra. São Paulo, Hedra: 2005.

FAVARETTO, Celso Fernando. Arte contemporânea - obra, gesto e acontecimento. In: FAVARETTO, Celso Fernando; MORENO, Arley R. (org) Filosofia, Linguagem, Arte. (série Cadernos PUC, 21). São Paulo: EDUC, 1985.

2000.

A Invenção de Hélio Oiticica. São Paulo: Edusp,

.Transformar a arte, mudar a vida. In: SOUSA, Edson Luiz André de; TESSLER, Élida; SLAVUTZKY, Abrão. (orgs.) A invenção da vida: arte e psicanálise. Porto Alegre: Artes e Ofícios, 2001, pp. 106-12.

.Do moderno ao contemporâneo. Registros Multimídia

dos Seminários Internacionais Museu Vale do Rio Doce 2006 
- Arte no Pensamento Contemporâneo. Vila Velha-ES: Fundação Companhia Vale do Rio Doce, 2006, pp.251-7. Disponível em: www.artenopensamento.org.br/palestras.php . Acesso em: 12 dez 2008.

A cena contemporânea, criação e resistência. In: FONSECA, Tânia Galli; PELBART, Peter Pál; ENGELMAN, Selda. A vida em cena. Porto Alegre: Editora da UFRGS, 2008, pp.13-22.

Inconformismo estético, inconformismo social, Hélio Oiticica. In: BRAGA, Paula. (org.) Fios soltos: a arte de Hélio Oiticica. São Paulo: Perspectiva, 2008, pp. 15-22.

FITZGERALD, Francis Scott. Crack-Up (O Colapso) - editado por Edmundo Wilson. (trad. Rosaura Einchenberg). Porto Alegre: LP\&M, 2007, p. 326. [The Crack Up.Charles Scribner's Sons, New York, 1931.]

FORTES, Hugo. Grand Tour 2007 - Cobertura a várias mãos: Um olhar sobre a Documenta12. Disponível em: http://www.canalcontemporaneo.art.br/quebra/archives/2007 08.html Acesso em: 20 nov. 2007.

FOUCAULT, Michel. Sobre a História da Sexualidade. In: FOUCAULT, Michel. Microfísica do Poder. Org e trad. Roberto Machado. Rio de Janeiro: Edições Graal, 1979, pp. 243-276. [Le jeu de Michel Foucault (entretien avec D. Colas, A. Grosrichard, G. Le Gaufey, J. Livi, G. Miller, J. Miller, J.-A. Miller, C, Millot, G. Wajeman), Ornicar?, Bulletin Périodique du champ freudien, n. 10, juillet 1977, pp. 62-93].

História da Sexualidade 2 - o uso dos prazeres. Trad. Maria Thereza da Costa Albuquerque. Rio de Janeiro: Edições Graal, 1984.

O que é um autor? (Trad. António Fernando Cascais e Eduardo Cordeiro). Portugal: Vega, 2000. [Qu'est-ce qu'um auteur?, Paris, ed:data].

GAGNEBIN, Jeanne Marie. Walter Benjamin ou a história aberta. (Prefácio). In: Magia e técnica, arte e política: ensaios sobre literatura e história da cultura. Trad. Sérgio Paulo Rouanet. 7ed. São Paulo: Ed. Brasiliense, 1994.

História e Narração em Walter Benjamin. 2a ed. São Paulo: Perspectiva, 2004.

Introdução (Prefácio). In: O que resta de Auchwitz. Trad. Selvino J. Assmann. São Paulo: Boitempo Editorial, 2008. 
GALLIO, Giovanna; CONSTANTINO, Maurizio. François Tosquelles - a escola da liberdade. In: LANCETTI, Antonio (dir.). SaúdeLoucura n.4. São Paulo: Hucitec, 1994, pp.85-128.

HANSEN, João Adolfo. Eu nos faltará sempre. (prefácio) In BECKETT, Samuel. O inominável. Trad. Ana Helena Souza. São Paulo: Editora Globo, 2009.

KASTRUP, Virgínia. A invenção de si e do mundo. Belo Horizonte: Autêntica Editora, 2007.

KASTRUP, Vírginia. A invenção de si e do mundo. Uma introdução do tempo e do coletivo no estudo da cognição. Campinas -SP: Papirus, 1999.

KURZ, Robert. Novas relações sociais não podem ser criadas por novas tecnologias. Rev. IHU on-line. n. 161, 24 out 2005, pp. 09 - 13. São Leopoldo - RS: Instituto Humanitas Unisinos. Disponível em: http://www.ihuonline.unisinos.br/uploads/edicoes/1158347724.5pdf.pdf Acesso em: 22 outubro de 2009.

KOSSOVITCH, Leon. Rancière e a Labor. Textura - revista de psicanálise. São Paulo, ano 5, n. 5, 2005, pp. 16-9.

LAPOUJADE, David. Do campo transcendental ao nomadismo operário. In: ALLIEZ, Éric. (org.). Gilles Deleuze: uma vida filosófica. Coord. da tradução Ana Lúcia de Oliveira. Rio de Janeiro: Ed. 34, 2000. [Gilles Deleuze. Une vie philosophique. Paris: Institut Synthélabo, Le Plessis-Robinson, 1998.]

. Simpatia, deambulação e devir. Vídeo da Conferência oferecida na Ocupação UEINZZ. São Paulo: SESC - Av. Paulista, 19 de outubro de 2009. Disponível em: http://www.tvaovivo.net/home2010/player_sl.aspx?key=17170097F904-4A0D-B750-BAD73B56C54B Acesso em: 20 out 2009

LAWRENCE, D. H. Walt Whitman. Trad. Ana Luísa Faria. Lisboa-Portugal: Relógio D’Água Editores, 1994.

LIMA, Elizabeth M. F. de Araújo. Arte, clínica e loucura: território em mutação. São Paulo: Summus Editorial e FAPESP, 2009.

LYOTARD, Jean-François. Entrevista con Jean-François Lyotard (Paris 13/12/86). Rev. de filosofía A Parte Rei. (rev. eletrônica) n. 49, janeiro de 2007. Disponível em: http://serbal.pntic.mec.es/ cmunoz11/lyotard49.pdf Acesso em: 17 de junho de 2009. 
MANTERO, Vera. A desfazer-se. Elipse - gazeta improvável. Lisboa, v.1, primavera-1998, pp. 03-4.

NANCY, Jean-Luc. La Comunidad Inoperante. Trad. Juan Manuel Garrido Wainer. Santiago de Chile: LOM/Arcis, 2000. [La communauté desoeuvrée. Paris: Christian Bourgois éditeur, 1986.]

La Comunidad Desobrada. Trad. do francês Pablo

Perera. Madrid: Arena Libros, 2001. [La communauté desoeuvrée, Paris, Christian Bourgois éditeur, 1986.]

Conloquium (prefácio). In: ESPÓSITO, Roberto. Communitas. Origen y destino de la comunidad. Trad. Carlo Rodolfo Molinari Marotto. Buenos Aires: Amorrortu, 2003, pp. 9-19. [Communitas. Origene e destino della comunità. Turim: Giulio Einaudi editore, 1998.]

La comunidad enfrentada. Trad. Juan Manuel Garrido. Buenos Aires: Ediciones La Cebra, 2007. [ $\mathrm{La}$ communauté affronté. Paris: Galilée, 2001.]

NIETZSCHE, Friedrich. Crepúsculo dos Ídolos, ou Como se filosofa com o martelo. Trad. Paulo César de Souza. São Paulo: Companhia das Letras, 2006. [Götzen-Dämmerung oder Wie man mit dem Hammer philosophiert, 1888].

A Gaia Ciência. Trad. Paulo César de Souza. São Paulo: Companhia das Letras, 2001.[Die fröhliche Wissenschaft, 1882, 1887.]

Escritos sobre Educação. Trad. Noéli Correia de Melo Sobrinho. Rio de Janeiro: Ed. PUC-Rio, São Paulo, Edições Loyola, 2003.

PASSOS, Eduardo; BARROS, Regina Benevides. A construção do plano na clínica e o conceito de transdisciplinaridade. Rev. Psicologia: Teoria e Pesquisa. Jan-abr 2000, v. 16, pp. 71-79.

PELBART. Peter P. Da clausura do fora ao fora da clausura - loucura e desrazão. São Paulo: Editora Brasiliense, 1989.

A Nau do Tempo Rei - sete ensaios sobre o tempo da loucura. São Paulo: Imago, 1990.

A vertigem por um fio. São Paulo: Iluminuras, 2000.

Iluminuras, 2003. 
Vida nua, vida besta, uma vida. Rev. Trópico. 25/10/2006. Disponível em: http://pphd.uol.com.br/tropico/html/textos/ 2792,1.shl Acesso em: 16 jun 2007.

A potência de não. In: FURTADO, Beatriz; LINS,

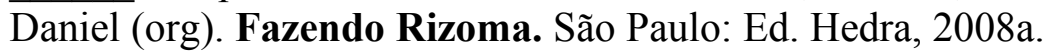

. Como viver só. In: BIENAL DE SÃO PAULO $\left(27^{\mathrm{a}}\right.$ : 2006). 27 ${ }^{a}$ Bienal de São Paulo: seminários. Curadoria geral Lisette Lagnado. Rio de Janeiro: Cobogó, 2008b.

. Vozes da desrazão no teatro da loucura. In: In: FONSECA, Tânia Galli; PELBART, Peter Pál; ENGELMAN, Selda. A vida em cena. Porto Alegre: Editora da UFRGS, 2008c, pp. 23-31.

PERRONE-MOISÉS, Leyla. Texto, crítica, escritura. $3^{\mathrm{a}}$.ed. São Paulo: Martins Fontes, 2005. [1 ${ }^{\mathrm{a} e d}$ - São Paulo: Ed. Ática, 1978]

PESSANHA, Juliano Garcia. Instabilidade Perpétua. São Paulo: Ateliê Editorial, 2009.

RABINOW, Paul. Antropologia da Razão. Trad. João Guilherme Biehl. Rio de Janeiro: Relume-Dumará, 2002.

RANCIÈRE, Jacques. O mestre ignorante. Trad. Lílian do Valle $2^{\mathrm{a}}$ ed. Belo Horizonte: Autêntica Editora, 2005.

RIERA, Alejandra. Maquetas-sin-cualidad. (fragmentos). Un problema no resuelto, $<1995-. .>$, vistas parciales um trabajo inacabado (trad. Carlos Manzano). Producción autónoma. Barcelona: Fundació Antoni Tàpies, 2004.

. Notesdocumenta5. (Formulação provisória de escrito a ser publicado por ocasião da apresentação da experiência na Documenta 12 de Kassel), Paris, 2006. (no prelo)

Nesse mundo do concreto (enquete sobre o/nosso entorno, 3a.parte) - trabalho em curso. São Paulo: SESCAvenida Paulista, 2009.

SÄKÖ, Maria. [Instantâneo: Em Finnegans ueinzz o mundo não é categorizado, mas criado. Trad. para o inglês Akseli Virtanen; trad. para o português Elisa Band - rev. John Laudenberger.] Jornal Helsingin Sanomat, Helsinque-Finlândia, 22 nov 2009. 
SIMONDON,Gilbert. A gênese do indivíduo. Trad. Ivana Bentes. In. COSTA, Rogério; PELBART, Peter Pál (orgs.). Cadernos de Subjetividade. - o reencantamento do Concreto. São Paulo: EDUC, 2003.

L'individu et sa genèse physico-biologique. Paris: Presses Universitaires de France, 2005.

TIQQUN. Theorie du Bloom. Revista Tiqqun 1, Paris, 2001, pp. 23-45.

VALÉRY, Paul. Monsieur Teste. Trad. Cristina Murachco. São Paulo: Editora Ática, 1997.

VILLANI, Arnaud. De l'esthétique à l'esthésique: Deleuze et la question de 1'art. In: BEAULIEU, Alain. Gilles Deleuze, heritage philosophique. Paris: Presses Universitaires de France, 2005.

VIRNO, Paolo. Virtuosismo e Revolução. A idéia de "mundo" entre a experiência sensível e a esfera pública. Rio de Janeiro: Civilização Brasileira, 2008. [Mondanità: L'idea de "mondo" tra esperienza sensible e sfera pubblica. Roma: Manifesto Libri, 1994.]

Multidão e princípio de individuação. Rev. Trópico. 07/11/2002. Disponível em: http://p.php.uol.com.br/tropico/html/textos/ 1479,1.shl Acesso em: 13 ago 2009.

WISNIK, José Miguel. O Som e o Sentido - uma outra história das músicas. São Paulo: Companhia das Letras, 1989.

WOOLF, Virgínia. Os diários de Virgínia Woolf.(Seleção e tradução José Antonio Arantes). São Paulo: Companhia das Letras, 1989, p.186. [The Diary of Virgínia Woolf. (Organização Quentin Bell e Angelica Garnett). Londres, The Hogarth Press, 1977.]

As Ondas. Trad. Lya Luft $2^{\mathrm{a}}$ ed., Ed. Nova Fronteira: Rio de Janeiro, 2004. [The waves. Hogarth Press: Londres, 1931] 